Historic, Archive Document

Do not assume content reflects current scientific knowledge, policies, or practices. 



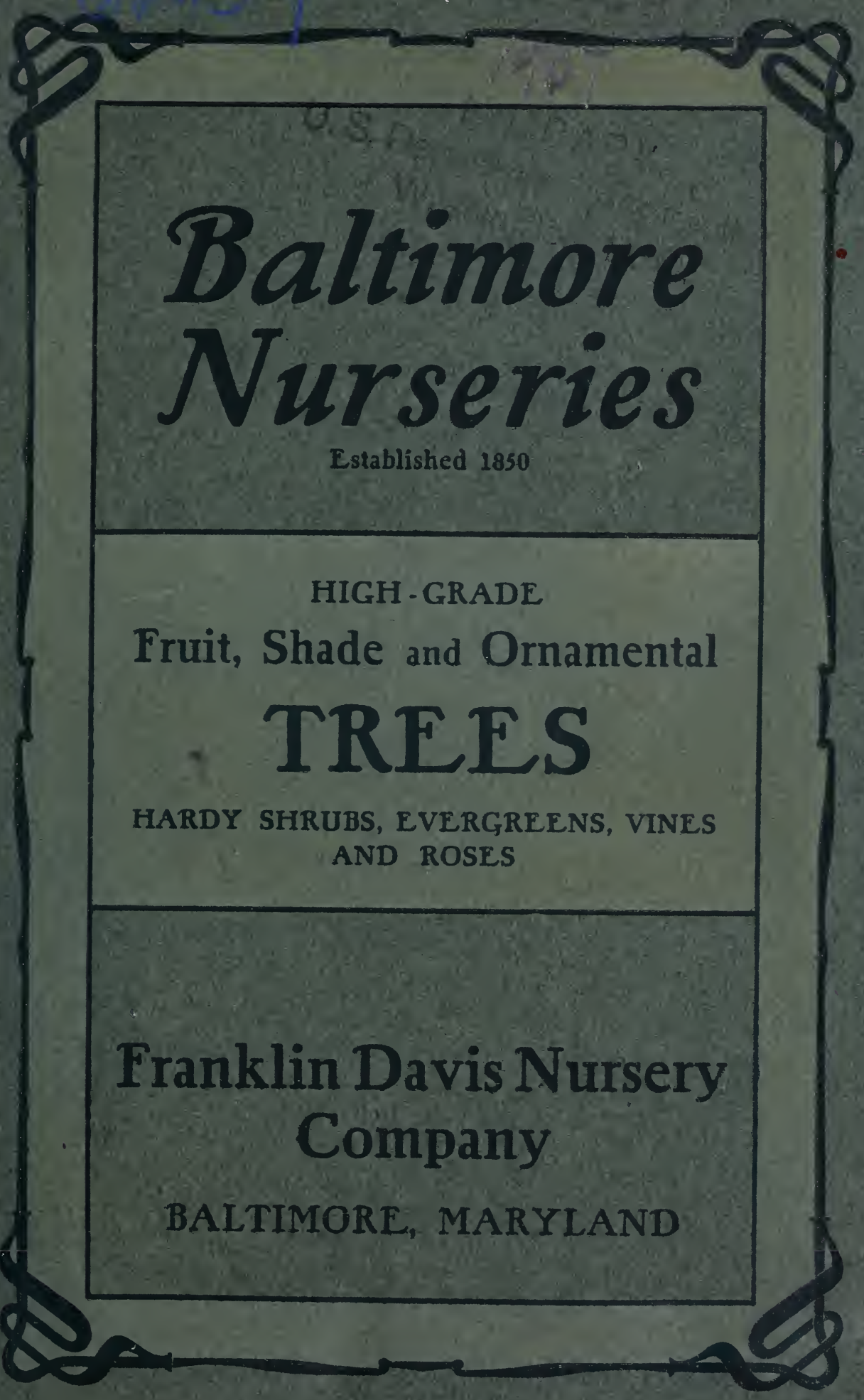


tex 


\title{
Fruit and Ornamental Trees, Shrubs, Vines and Plants
}

\author{
CULTIVATED AND FOR SALE BY
}

\section{The FrankLin Davis Nursery Co.}

\author{
BALTIMORE, MD.
}

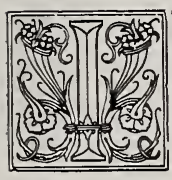

T IS once more our pleasure to present to our friends and patrons a new edition of our Descriptive Catalogue of Fruit and Ornamental Trees, etc., and in doing so we tender to them our sincere thanks for the many expressions of encouragement and substantial aid they have given us. We will endearor in the future, as we have in the past, by strict personal attention to business, to merit their patronage and good will.

In 1877, at the exhibition of the American Pomological Society at Baltimore, we were awarded a "Wilder" medal for the largest and finest collection of Apples. With these and other evidences of our success, and the many encouraging words of our friends, we do not feel like relaxing our efforts, but, on the other hand, are induced to push on with renewed energy; and while we are adding to our acres we are also watching closely all the new fruits that are brought to notice throughout the country. If their merits seem to justify it, we add them to our list, and at the same time discard those that have proved less raluable. Our Catalogue is, therefore, under revision all the time, and every succeeding list that we make is an improvement upon the one preceding it.

There are three considerations that claim the attention of purchasers of nursery stock: First, it is of the greatest importance to procure a fine article, true to name. Secondly, it is of vital importance to secure good, healthy stock, for without a healthy plant to begin with, we have but a poor chance of success; one healthy stock is worth a dozen sickly ones. Thirdly, success often depends on careful packing; without it thousands of dollars' worth of trees are annually lost.

To secure the first, we have tested in our specimen orchards nearly all the leading varieties of fruit, and our orchards, being planted in different localities, enable us to judge the merits of the fruit and its success in different soils and situations. We will propagate largely only of sorts we know will succeed in the section in which we intend selling them. Secondly, we will send out nothing but good stock. Thirdly, our packing will be done in the best manner, and by experienced hands, so as to insure the safe transit of the trees.

A change has taken place in the labor systen of the Southern states, and with it comes a change in the pursuits of many of their people. Many are looking about undecided as to what they shall undertake. We believe that fruit-growing offers greater inducements than anything else. Under this conviction we have gone largely into the business ourselves, and say to others, "go and do likewise," and, if sou give it proper attention, we will guarantee satisfactory returns.

Maryland is already noted for her extensive peach orchards, which are indeed a large and profitable interest in the state; yet, there is room to extend them far beyond their pres. ent proportions, and with great certainty of profitable results. Other fruits are very properly receiving more attention throughout the state.

Virginia, from her climate, soil and geographical position, must at no distant date become famous for the products of her orchards; and whosoever does the most to bring this about must be looked upon as a public benefactor. To this end we aspire.

\section{FRANKLIN DAVIS NURSERY CO.}

N. E. Cor. Baltimore and Paca Sts., BALTIMORE, MD. 


\section{TO CORRESPONDENTS}

In the transaction of any business, a mutual desire for mutual satisfaction between parties should prevail. Let us, then, ask of our patrons an observance of the following requests:

That all orders addressed to us be written out in a legible style, and the name in full, that no mistakes may occur.

That particular and plain directions be given how they wish their packages marked, and by what route sent, and to whose care consigned. When no route is designated, we will send by the one we deem most advisable; but let it be distinctly understood that we will, in no case, be responsible for any loss or damage that may occur after we have delivered them to the forwarders. They alone are responsible.

While we exercise the greatest care to have all our trees and plants true to name, wellgrown and packed in the best possible manner, and hold ourselves in readiness, on proper proof, to replace all trees or plants that may accidentally prove untrue to label, free of charge, or refund the amount paid therefor, it is mutually understood and agreed to between the purchaser and ourselves that our guarantee of genuineness shall in no case make us liable for any sum greater than that originally received for trees or plants that prove untrue. Our reputation for upright dealing, and the uniformly high standard of quality of our products, the result of a 57 years' business career, is our only guarantee to our customers.

When orders are received specifying the kinds wanted, the purchaser will please say whether we shall fill up with other varieties, should some of those which he has ordered be exhausted. We will, so far as in our power, give him his choice; but when the varieties specified cannot all be furnished, or are known to be unworthy of cultivation, we will take the liberty of substituting others in their place, unless special orders are given to the contrary. When the purchaser is not well acquainted with the fruit by name, he would do well to leave the selection to us, briefly stating at what season he wishes the fruit to ripen; and in such case we will exercise our best judgment in making a judicious and profitable selection of the standard sorts and of good trees.

Prompt attention will be given to all letters requesting information, all of which should enclose a postage stamp.

It is expected that orlers for trees from those with whom we have no acquaintance will be accompanied with the cash or a suitable reference.

Our terms are invarlably cash, or a negotiable note of short time, satisfactorily endorsed, made payable at bank.

To all the points where the express companies have an office we can send trees marked C. O. D. This will save the purchaser, as well as ourselves, some trouble.

When the cash accompanies the order, no charge is made for packing.

From past experience we have learned that we cannot afford to delay collections, and must henceforth insist upon prompt payment. Our business is attended with heary expenses, and we must have the cash to push it.

Trees, plants, etc., will be carefully taken up, each kind tied by itself and labeled, and the roots packed so as to carry safely.

\section{HINTS ON TRANSPLANTING}

The proper season for transplanting fruit trees is during the $m>n$ ths of February, March and April in the spring, and October, November and December in the autumn.

The ground should be well prepared by at least two good plowings: let the subsoil plow follow in the furrow of the other, loosening up the earth to the depth of 12 to 18 inches. If the ground is not in good condition, it should be made so by the application of a considerable portion of well-decomposed manure, or fertilizer of some substantial kind.

Dig the holes sufficiently large to admit the roots, giving them their natural position as near as practicable. Use the surface soil for filling in, having it first well pulverized. Avoid deep planting, for it is decidedly injurious to the tree, and, when excessive, may cause its death, or a weak and feeble growth. Plant no deeper than it stood in the nursery.

Immediately before planting, all the bruised or wounded parts should be pared off smoothly; then dip them in a bed of mud, which will coat over every part evenly, and leave 


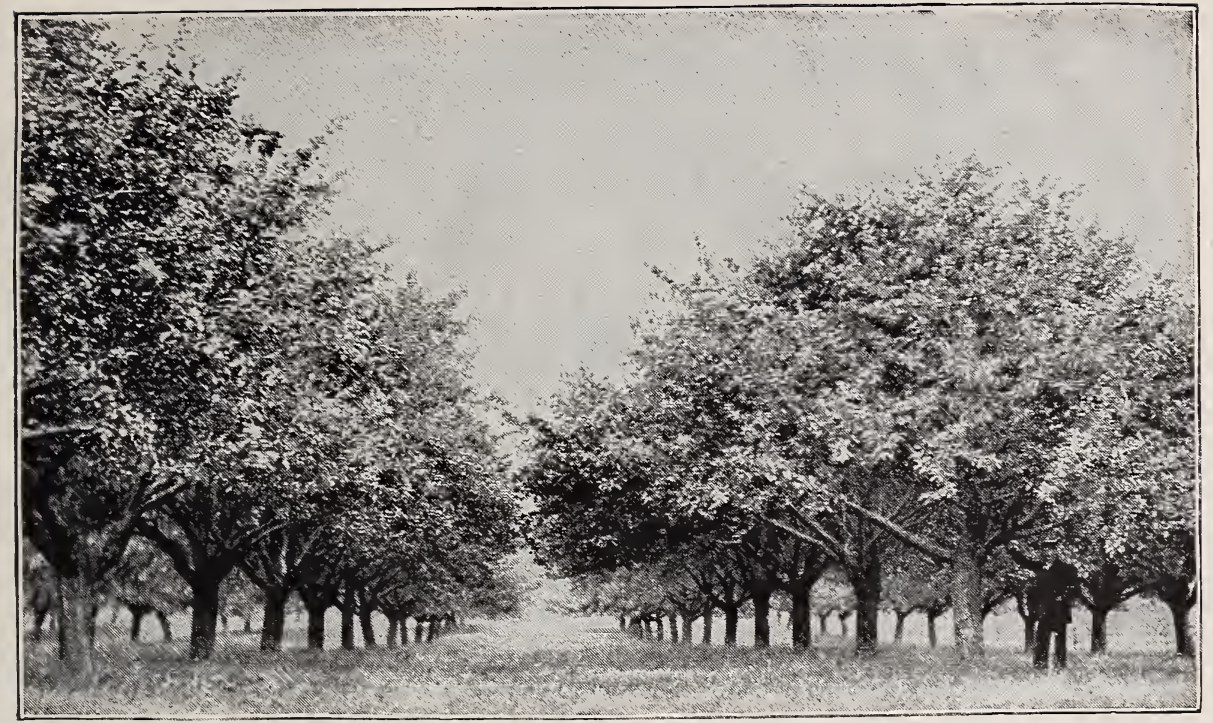

no portion in contact with the air, which, accidentally, might not be reached by the earth in filling the hole. If the trees have been out of the ground for a long time, and have become dry and shriveled, they should be immersed in water for 24 hours before planting. Fruit trees sometimes remain with fresh and green branches, but with unswollen buds, till midsummer; instead of watering such at the roots, let the body and branches be wet every evening regularly, about sundown, with a watering pot; this will, in nearly all cases, bring them into active growth.

However carefully trees may be taken up, they will lose a portion of their roots, and if the whole top is allowed to remain, the. demand will be so great upon the roots that in many cases it will prove fatal to the tree. To obviate this, it becomes necessary to shortenin the branches, which should be done at the time of planting. If the tree has lost the greater part of its roots, a severe shortening-in of the branches will be necessary; if only a small portion of its roots has been cut off, more moderate pruning will be sufficient.

Mulching is another very important matter, particularly in this climate, where we frequently experience severe midsummer droughts. It consists in covering the ground about the tree with a coarse litter, straw, leaves, shavings, or anything that will shade the ground and prevent evaporation. It should be done early in the spring, and will, in most cases, obviate the necessity of watering at the roots.

Cultivating. - While it is very important to have trees well planted, it is doubly important to have them well cultivated afterwards. Give your trees for a few years a clean, mellow ancl fertile soil, and they will bend under copious loads of fine fruit, and yield to the cultivator his reward. Dwarf Pears, more than any other trees, require a deep, rich soil, and clean cultivation. In cultivating, great care should be taken not to injure the trees by rubbing the bark off. The best crops for an orchard are those requiring summer culture-such as potatoes, beans, etc.

Pruning.- We recommend the greatest care and moderation in this operation, believing, as we do, that upon the whole there is more injury done by the use of pruning instruments in unskilled hands than would result from its entire neglect. Some of the objects sought are to diminish the thick growth, to increase the vigor of the branches, to admit light and air, and to form a well-shaped top. Occasional pinching or cropping off of the ends of branches to give the tree proper shape, and removing those that cross or crowd each other, will be all that will be needed by most trees. Peach trees would be greatly benefited by an annual shortening-in of the branches, say one-half of the previous year's growth; this may be done at any time after the fall of the leaf until the buds commence swelling in the spring; they 
nerer need any thinning out of the branches. Dwarf Pears also need careful attention annually, to keep them in shape, by cutting back the rampant and straggling shoots; they should be pruned down instead of up, never allowing them to grow high, or the top will become too heary for the roots, and increase the danger of blowing down.

\section{PROPER AGE AND SIZE OF TREES FOR TRANSPLANTING}

Experience has taught observing planters that a small, young tree, set at the same time, will in a few years overtake and pass a larger one, and continue more vigorous and productive. Large trees are necessarily or unavoidably more injured in digging than small ones. The latter can be mored with their system of roots almost entire. This is another reason why there is less risk in planting small trees.

\section{DISTANCES FOR PLANTING}

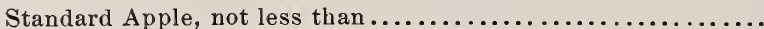

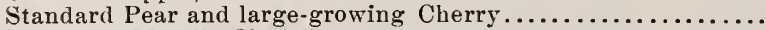

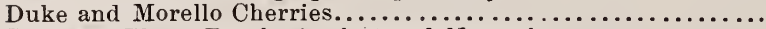

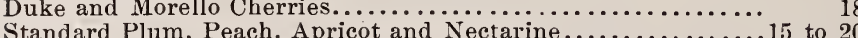

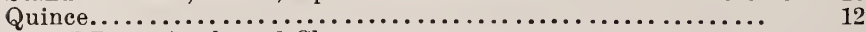

Dwarf Pear, Apple and Cherry....................... 10

Dwarf Cherries of the Duke and Morello varieties........... 8

Currants, Gooseberries and Raspberries.................... to 5

Grapes......................................6 to 10

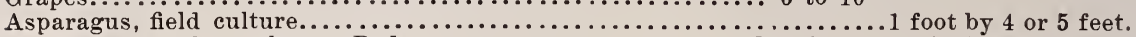
garden culture. Berls..................... 12 inches by 12 inches each way.

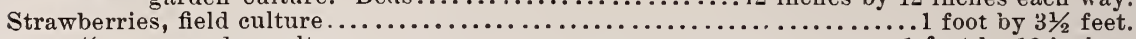

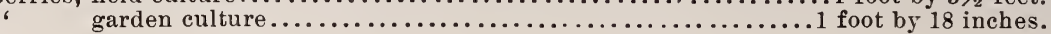

\section{NUMBER OF TREES ON AN ACRE AT VARIOUS DISTANCES}

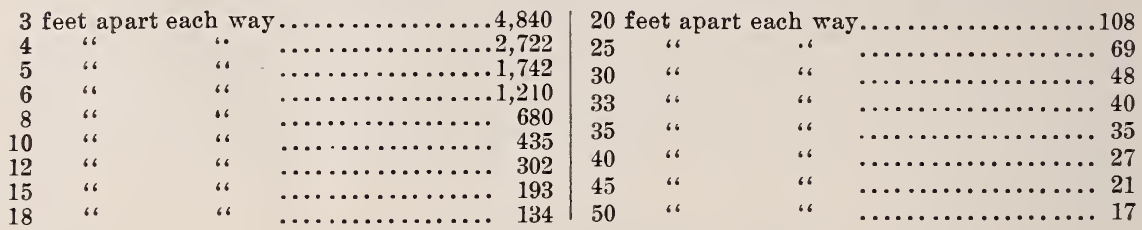

\section{NUMBER OF PLANTS REQUIRED TO PLANT AN ACRE}

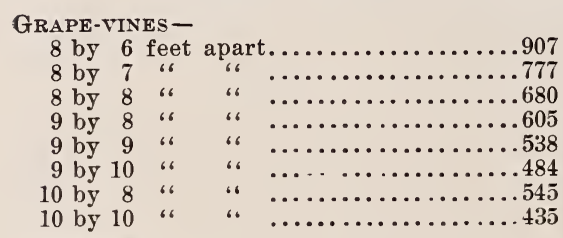

Currants -

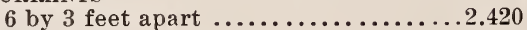

6 by 4

\section{Gooseberries-}

6 by 3 feet apart..................2,420

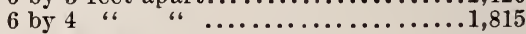

RASPBERRIES -

6 by 3 feet apart.................2,420

7 by 3 " " . . . . . . . . . . . . . 2,075

BLACKBERRIES -

6 by 3 feet apart..................... 420

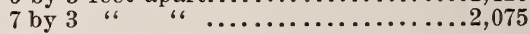

STRAWBERRIES-

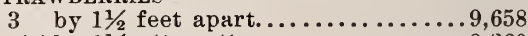

$31 / 2$ by $11 / 2$ "،

\section{Extracts from Letters}

Car of shrubbery received and unloaded November 19 from your Nursery. Stock was carefully packed and received in first-class condition, and is the best lot of shrubbery and trees that $I$ have handled while in the landscape business. I thank you kindly for the care taken and for the stock you shipped. Will you kindly send to my address the price charged for each variety sent, as I am planting on different divisions of the P. R. R. and must charge and make report as material is furnished. I will thank you very much if you will send prices at your earliest convenience.-J. F. SMiTH, P. R. R. Gardener.

In a letter just received from Mr. Converse acknowledging carload of trees, he says; "Manager Drew spoke very enthusiastically of the splendid specimens shipped, and from what little I know about these things I should judge that you had obtained some very fine plants and trees." There were other trees besides yours, but yours were O. K.-E. H. BISSEL.

I can recommend the Franklin Davis Nursery Company as a thoroughly reliable firm. They furnish the grower splendid trees and roots to grow them (a fault with many nurserymen not giving sufficient roots). I have always found their stock No. 1 and true to name.-Thomas J. Vickers.

The 1,500 hedge roots received in first rate shape, and wish to say they are the finest 2-year-olds $\mathbf{I}$ have ever handled. Not one faulty root in the whole lot.-Chement HenLY. 


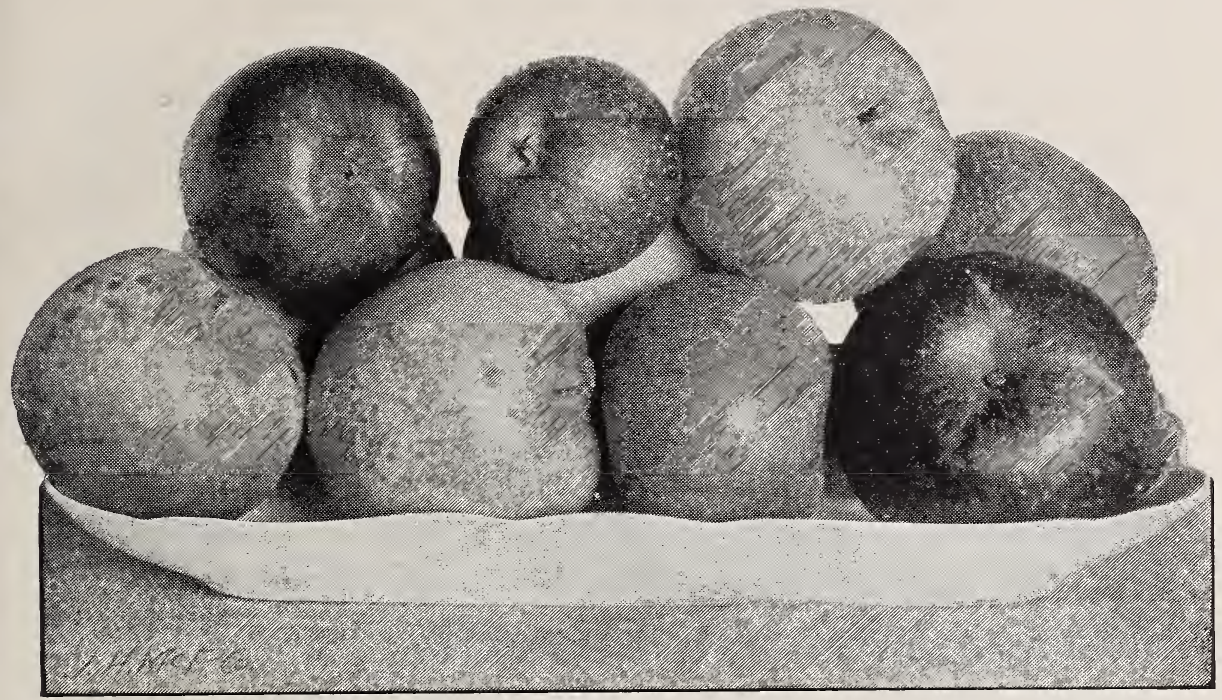

\section{\#ruit Bepartment}

\section{SELECT APPLES}

"The Apple," says Downing, "is the world-renowned fruit of temperate climates." Our list embraces the best and most popular varieties known. Of course, it runs into too great a variety for any one orchard for profit; besides, there is probably not a spot in the country where they would all flourish, but the latitude of our trade not only admits of, but demands a large list to supply the wants of the different sections of the country. After an experience of many years in the nursery and fruit-growing business, we have, with great care, made the following selections, from which we trust all our patrons can supply their wants.

\section{SUMMER VARIETIES}

American Summer. (American Summer Pearmain.) Medium size, oblong; nearly covered with streaks and dots of red; flesh tender, juicy and rich, subacid flavor; fine. Tree a slow grower, but bears early and abundantly; continues in use for severai weeks. One of the very best Apples. Last of July to August.

Bough. (Sweet Bough.) Large, roundish, sometimes conical; pale yellow; flesh white, very tender, with an excellent, sweet flavor. Tree moderately vigorous and very productive. Best sweet Apple of its season. July.

Benoni. Medium size, round; deep red: flesh yellow, tender, subacid. An excellent Apple. July.

Carolina June. (Carolina Red June.) An early bearer; productive; fruit medium size, dark crimson; flesh white, very tender. fine-grained, juicy, subacid. June and July.

Early Harvest. Rather large, round; yellow; flesh nearly white, tender, juicy, crisp, with a rich, sprightly subacid fiavor. Tree a moderate grower and very productive. Taking all its qualities into consideration, this has no superior among early Apples. June and July.
Early Ripe. This fine Apple, coming as it does iminediately after the Early Harvest, fills a want long felt by the orchardist. Its large size, handsome appearance and good bearing qualities combine to make it the most profitable market variety of its season. The tree is hardy and of vigorous growth; fruit large, yellowish white; flesh white, juicy, subacid; fine for the table or for cooking. First of July.

Early Strawberry. Medium size; nearly covered with red; flesh tender, with a mild, fine flavor. Tree a moderate grower and good bearer. July and August.

Fanny. Handsome, slightly conical fruit of deep rich crimson; tender, juicy, subacid. Begins to ripen just before Red Astrachan is done; keeps better and is of better quality.

Fourth of July. A German Apple introduced by C. F. Jaeger, of Columbus, Ohio. Very valuable for cooking and market. Fruit medium, roundish oblate, conical, slightly ribbed; whitish yellow, striped and splashed with bright red. It has been thoroughly tested and found to be one of the very best early Apples. Matures early in July.

Horse. Large; yellow; flesh coarse, subacid; fine for cooking and for market. Tree vigorous. August. 


\section{The Franklin Dabis Nursery Company}

SUMMER APPLES, continued

Red Astrachan. Rather large, approaching conical; covered with deep crimson, overspread with a thici bloom; flesh juicy, rich, acid. From its earliness, handsome appearance, its excellent culinary qualities, and the vigor of the tree, it is worthy of general cultivation. July.

Starr. The original tree of this most valu . able Apple was found on the grounds of Judge John Moore White, of Woodbury, N. J., which property afterwards came into possession of Mrs. Starr, whose son, John Starr, while in the Legislature with the late William Parry, about 1865 , gave him scions from which he grew and fruited it under the name of Starr Apple. It has proved a very valuable and desirable early market Apple, having created for itself such a reputation that it is always sought after and bought up by fancy grocers at ligh prices, even when other good varieties are selling low. The tree is a good grower, comes to fruiting young, and produces abundant crops annually. Fruit is very large, 11 to 12 inches around; showy pale green, frequently with handsome blush on sunny side; very early, marketable first week in July, and will continue in good condition until September. An excellent shipper for so early an Apple, having carried to California in good condition. Flavor pleasant, subacid. A very superior Apple for cooking or eating.

Tetofsky. A handsome Russian variety, very hardy. Tree vigorous and productive; comes into bearing early. Fruit medium size; skin yellow, striped with red; flesh white, fine-grained, acid. July.

Williams' Early Red. Large ; red, showy. Early to medium; productive. Good for cooking or eating; excellent for shipping or near-by market.

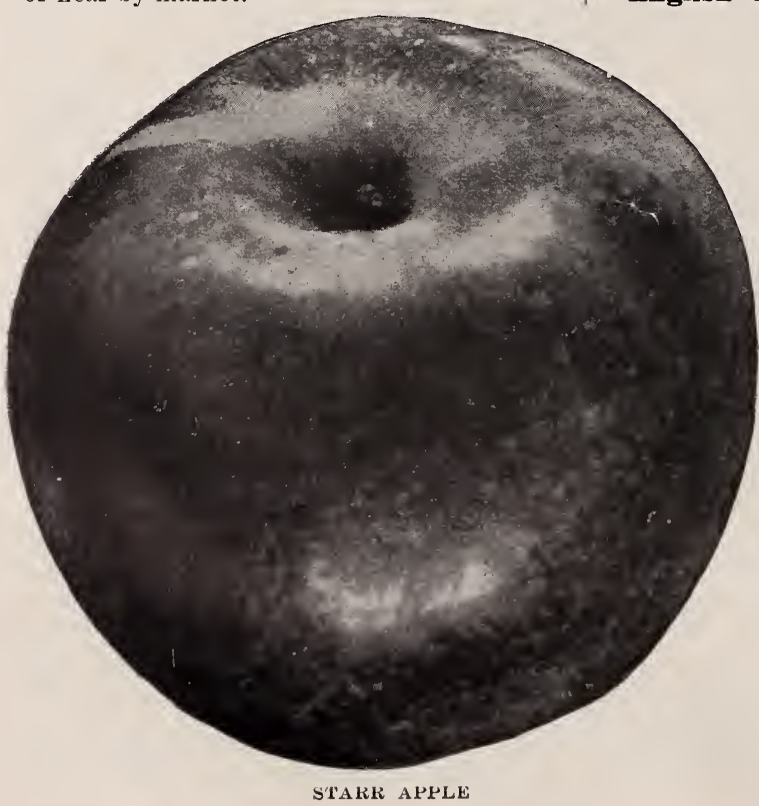

Yellow Transparent. A Russian Apple of great, value. Above medium size, roundish, oblate, slightly conical; skin a clear white, changing to pale yellow when fully matured. A remarkably early bearer; very prolific; tree a vigorous and upright grower. Gives general satisfaction, does well everywhere, and ripens among the earliest. July. (See illustration on page 7 .)

\section{AUTUMN APPLES}

Bismarck. Bears fruit on 2-year grafts. Of finest quality, finest color, dwarf, and extremely prolific; most suitable Apple for hot climate, yet the hardiest known. A prominent firm boldly asserts that 1-year gratts bore as many as eight fruits, that 2 yearold trees seldom fail to produce good crops, and that the tree is an excessive bearer and extremely hardy. The tree is of short, stocky growth, and when laden with handsome fruit at one or two years old, is a pretty pot-plant for table or greenhouse decoration. The tree is a hardy, vigorous grower, and the apples are very sound, solid and heavy. It is especially recommended for gardens when grafted on Paradise stock. Fruit is large, brilliantly colored.

Buckingham, or Winter Queen. Large to very large; greenish yellow, mixed and striped with crimson or purplish red; flesh yellowish, breaking tender, juicy, mild sprightly, subacid. A handsome, healthy tree; comes in bearing very early, and is very productive. This Apple is cultivated over a great portion of the southern and western states, and is everywhere very profitable and popular, succeeding in almost every locality. We consider it one of the most valuable sorts. October to January.

English Red Streak. Medium size; yellow, streaked with dark red; Hesh firm, yellow, fine-grained, rich and juicy. A good fall Apple. Sept. to Dec.

Fall Pippin. Very large, roundish; skin smooth, yellow ish green, becoming rich yellow when ripe; flesh yellowish, firm, becoming tender, rich, aromatic, excellent; valuable for cooking and market. Succeeds well everywhere. September to December.

Gravenstein. Large, roundish; striped with red ; flesh tender, juicy, very rich, subacid, high flavor. Productive, handsome and excellent. Fine in all localities. Angust.

Golden Sweeting. Rather large; rich yellow; flesh juicy, tender and sweet. August.

Jefferis. A fair and handsome fruit of excellent quality, in use all of September; fruit medium, oblate; yellow, shaded and splashed with crimson, and thickly covered with large whitish dots; flesh white, tender, juicy, with a rich, mild, subacid flavor; very good. Sept. 


\section{AUTUMN APPLES, continued}

Jersey Sweeting. Medium-sized; striped with red; flesh whitish, very sweet, juicy and tender; flavor very good. Succeeds well in all localities. Sept. and Oct.

Maiden's Blush. Rather large, oblate, smooth, regular, with a fine, evenly shaded red cheek, or blush on a clear pale yellow ground; flesh white, tender, sprightly, with a pleasant subacid flavor. This variety forms a handsome, rapidgrowing tree with a fine, spreading head, and bears large crops. Aug. to Oct.

Ohio Nonpareil. This is among the best dessert Apples of the season. It is declared to be "better than the best." Fruit large to vers large, oblate, very handsome; yellow, covered with bright red; flesh yellowish, tender, fine-grained, juicr, subacid; first quality for table or cooking. September to December.

Oldenburg. (Duchess of Oldenburg). A Russian variety of very handsome appearance and great value; tree very hardy, vigorous, and an abundant bearer; fruit medium to large, golden yellow, nearly corered with streaks of crimson; flesh tender, juicy, pleasant. Valuable for the market. August.

Red Bietigheimer. German origin. Fruit large to very large, roundish, inclining to conical; skin pale, cream-colored ground, mostly corered with purplish crimson; flesh white, firm, subacid, with a brisk, pleasant flavor; tree a vigorous grower and abundant bearer; worthy of general cultivation. September.

Rambo. There is not, perhaps, another Apple named in this catalogue so widely disseminated, or which was once so generally esteemed as this; but recently, in some locali ties, the trees have become less vigorous tlian formerly. 'They grow well until three or four years old, then, from some cause unknown to us, commence declining, and do but little good afterwards; but where it still succeeds it is one of the best Apples, and should be planted. Fruit abore medium size; skin smooth, streaked with dull rellowish red; flesh greenish white, very tender, with a rich, spicy, subacid flavor. October to January.

Summer Rambo of Pennsylvania. Very large, striped with red, on yellow ground; flesh mild, subacid, with an agreeable flavor. September.

Smokehouse. Fruit large, oblate, striped with red on yellow ground; flesh yellowish white, firm, juicy, crisp and rich, with a fine, aromatic, subacid flavor; unsurpassed for culinary purposes; productive; should have a place in every orchard. September to Dec.
Western Beauty (Big Rambo, or Ohio Beauty). Very large; pale yellow, striped and splashed with bright red; flesh yellow, tender, juicy; never water-cored and not disposed to rot; one of the best fall Apples. September to December. 
WINTER APPLES, continued

Arkansas Black. Fruit large, almost black; tree a vigorous grower. Fruit smooth and handsome, very dark; flesh yellowish, slightly subacid and erisp, A splendid keeper.

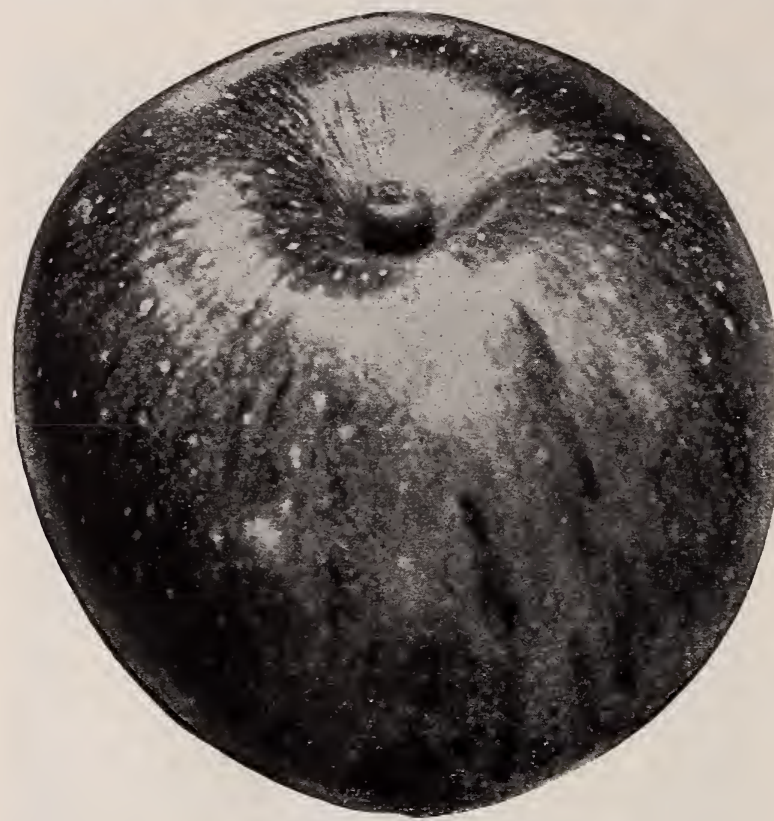

JONATHAN (See opposite page)
Ben Davis. Originated in Kentucky; tree remarkably healthy, vigorous, and an abundant bearer; fruit large, handsome, striped; flesh whitish, tender, juicy, subacid; a very profitable market variety; should be in every orchard. Keeps till midwinter or later.

Berry Red. A chance seedling from the farin of John Berry, of Meadow Creek, $\mathrm{Ky}$. Large to rery large ; color dark, bright, shining red; form oblate; flesh cream color; quality good, flavor excellent and retained through its long keeping season; subacid, rich, juicy. As a market rariety and long keeper it is second to none; an enormous bearer. In 1872,47 bushels were picked from the original tree, and in 1874 over 76 bushels. Many years it has averaged 40 bushels. A noble winter A pple; deserves a place in every collection.

Delaware Late Win. ter, or Lawver. A valuable winter Apple, especially in the South. Strong grower and abundant bearer; fruit medium to large, bright red, fine texture, subacid, juicy; long keeper. It promises to gain the standing in the South that Baldwin has in New England and Northern Spy in western New York. January to March.

Bellflower. Large, oblong, ovate; skin pale yellow, with sometimes a blush; flesh very tender, fine-grained, crisp, juicy, acid, becoming subacid; does not succeed in tidewater, nor soutl of James river, except in the mountain country. A general favorite where grown. October to January.

Baldwin. Large, roundish, narrowing a little to the eye; skin yellow in the shade, but nearly covered and striped witb red and orange in the sun; flesh crisp, juicy and subacid, rich; tree a vigorous grower and bears abundantly; succeeds well in western Maryland and the mountains of Virginia, but drops its fruit too early in or near the tide-water section. October to January-later in the mountains.

Bentley's Sweet. 'Supposed origin, Virginia; fruit medium, roundish, flattened at ends, sometimes slightly oblique, and sometimes sides unequal; pale, yellowish green, shaded with pale red, and moderately sprinkled with light and brown dots; flesh fine, whitish, compact, sweet, somewhat honeyed flavor; tree moderately vigorous, hardy, good bearer and keeper; very good. January to May.

Bonum. Large, oblate, color light to dark rerl; flesh yellow, firm, breaking, fine-grained; Havor rich, subacid, first quality for dessert; a most excellent apple; originated in North Carolina. A particularly valuable variety for the South. Deserves more general attention. October to January.
Dominie. Large size, flat, striped with red; flesh white, juicy, firm, mild, subacid, sprightly, pleasant flavor; keeps till midwinter; a rapid grower and prodigious bearer. Is well deserving of extensive cultivation.

Esopus Spitzenburgh. One of the standard northern winter apples, but not valuable here on account of the fruit specking on the trees; besides, it is a noor bearer.

Fallawater. Large, roundish, slightly ovate, conical, very regular, smooth; skin yellowish green, with a dull red cheek; flesh greenish white, fine-grained, with a mild, slightly subacid flavor; tree a strong grower and good bearer: fruit uniformly fair; highly deserving extensive cultivation. Nov. to Feb.

Fameuse (Snow Apple). Medium size, deep crimson; flesh snow-white, tender, melting and delicious; strong grower; dark wood. Valuable for both dessert and market; does best in the North. November to January.

Gano (Red Ben Davis). Fruit and tree closely resemble the well-known Ben Davis, but more highly colored; yellow, nearly covered with dark red; very handsome, large; flesh pale yellow; mild subacid. Season with Ben Davis. A good keeper.

Grimes' Golden. A native of Brooke Co., West Va.; an Apple of the highest quality. Dr. Warder says: "Too good for aught else but the dessert." Medium to large; flesh yellow, subacid, aromatic, spicy, rich, refreshing; tree hardy, vigorous and productire. January to March. 
WINTER APPLES, continued

Hubbardston Nonesuch. Origin, Massachusetts. Fruit large, handsome, round, tapering both ways from the middle surface; yellow, covered with mixed red and broken stripes; flesh yellow, juicy, tender, with fine, rich flavor. Deserves general cultivation; valuable for market and dessert. October to January.

Jonathan. Fruit medium or small, roundish; skin yellow, nearly covered with dark or lively red; fine-grained, very tender and finely flavored. This Apple is being planted extensively in all sections and deserves the attention of planters everywhere. Nov. to April.

Johnson's Fine Winter, or York Imperial. Medium size, truncated oval, angular; skin greenish yellow, nearly covered with bright red; flesh tender, crisp, juicy, aromatic; an enormous bearer, and hangs well on the tree; it is also a good keeper, retaining its flavor to the last. We cannot say too much in favor of this Apple; all things considered, it is scarcely second to any in the catalogue as a profitable orchard variety. February to April.

King. (Tompkins County). Very large, red-striped, handsome and of fine quality; a splendid Apple North, but not valuable here. November to February.

Kinnard's Choice. This splendid Apple originated in Tennessee; wherever known it is spoken of in the highest terms. Tree vigorous, and bears very young; fruit medium to large, highly colored, red; flesh yellow, fine-grained, tender, rich, juicy; keeps well. November to March.

Lankford's Seedling. Origin, Kent Co., Md. Tree hardy and a good bearer, bearing annual erops; fruit of large size, striped; quality excellent; keeps till April. This new sort possesses many valuable qualities, and will no doubt become a popular sort for late winter use.

Limbertwig. A wellknown southern Apple. Above medium size; color dull, purplish red; flavor subacid, rich, aromatic: productive, keeps well. February to April.

Lady Apple, or Pomme d'Api. Quite small, regular and flat; skin light, clear yellow, with a brilliant red cheek; flesh white, tender and juicy, with a pleasant, delicate, subacid flavor; a great bearer; brings the highest price of any fancy Apple in the market. December to April.

Long Is I and Russet. Medium round; russet.

McIntosh Red. Large, roundish, skin mostly covered with bright red; flesh white, tender, subacid, sprightly, very good; a handsome Apple of fine quality; strong grower. November to February.
Mammoth Black Twig (Arkansas Paragon). Originated in Arkansas. A seedling of the Winesap, which it resembles, but it is superior in many ways. Large, deep red; subacid; early and abundant bearer, and a good keeper. 'The tree is a strong grower, and roots well. This valuable winter Apple has few equals. December to April. (See illustration, page 10.)

Missouri Pippin. Large, oblong; bright red, with darker red stripes; very handsome; fair quality; a good grower and an early and immense bearer; often fruits at two years in nursery rows ; valuable for market. December to April.

Nickajack. This Apple is very widely disseminated in the southern states, where it is known under about forty different names, which is pretty good evidence that it has proved itself a valuable sort. Fruit large, roundish; skin striped and splashed with crimson; flesh yellowish, compact, moderately tender and juicy, subacid; quality only good. November to March.

Northern Spy. Large, conical, flattened; striped and quite covered on the sunny side with dark crimson, and delicately coated with bloom; flesh white, fine-grained, tender, slightly subacid; both leaf and blossom buds open a week later than most other sorts. An Apple of very high character, but we cannot advise its planting south of Pennsylvania, except in mountain regions. Noveinber to February.

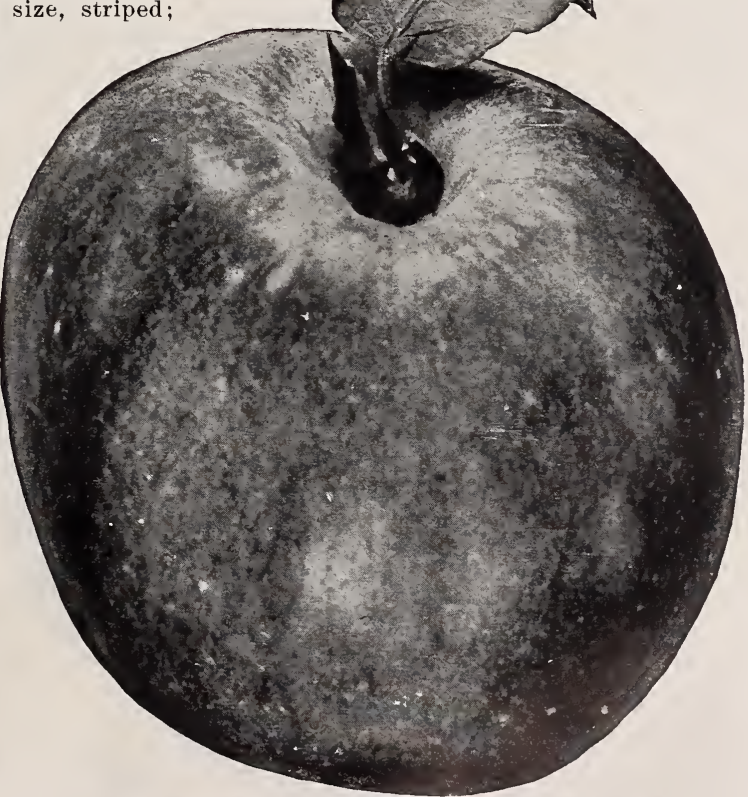

JOHNSON'S FINE WINTER, OF YORK IMPERIAL APPLE 


\section{WINTER APPLES, continued}

Northwestern Greening. A Wisconsin seedling of great value; has stood the most trying tests and found to be equal to Wealthy in point of hardiness, but superior in fruit and keeping qualities; large, smooth, greenish yellow; flesh fine-grained, juicy, firm; good quality; thoroughly tested. January to April.

Opalescent. Several years ago a number of Apple seedlings were found growing by an oak stump ill an orchard, presumably from cores or apples thrown there. When four to five feet high they were grubbed out and thrown away. Prompted by an afterthought, one of them was picked up and used to fill a vacancy in a row near by with a purpose to top-graft it when of sufficient size. Before this was done, however, it bore a few Apples which at once attracted attention as being quite unlike and superior to anything in the orchard. 'This original tree never fails entirely, and usually bears from a moderate to a full crop of superior fruit. Size, beauty and quality most happily unite in this remarkable Apple. All who have examined the Opalescent regard it as the handsomest Apple grown. It is not only highly colored, but susceptible of a very high polish, reflecting objects near it like a mirror. This feature makes it a highly prized sort for fruit stands. The flesh is yellowish, tender, juicy and good, size large to very large, and color light, shading to very dark crimson. Season, December to March. Sold only under copyright label, duly registered in the Patent Office at Washington.

Paradise Winter Sweet. Large, regularly formed, roundish; skin fair and smooth, dull green when picked, with a brownish blush; flesh white; fine-grained, juicy, sweet, sprightly and good; productive; an excellent Apple. Well worthy a place in the orchard. November to February.

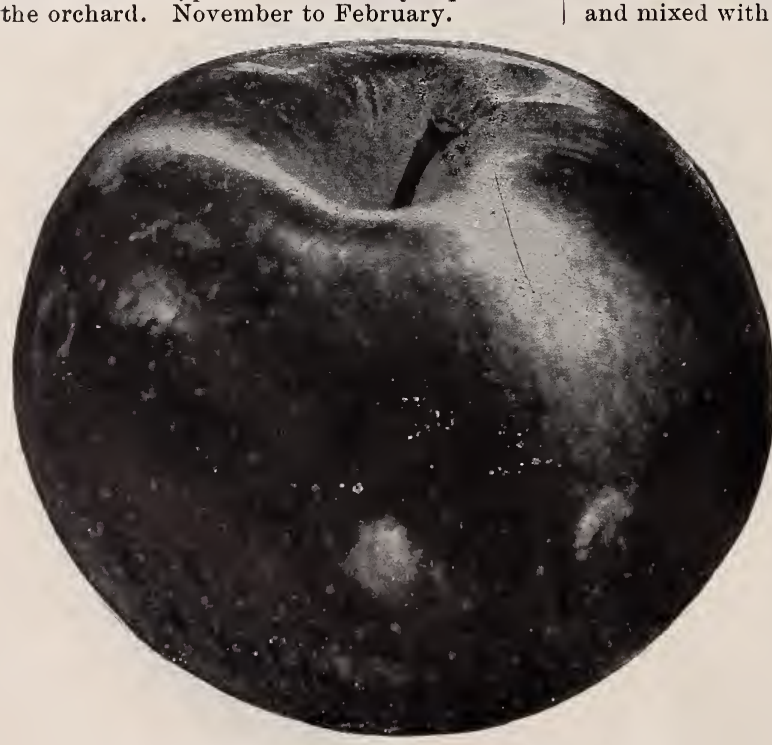

MAMMOTH BLACK TWIG APPLE (See page 9)
Pewaukee. Origin, Wisconsin. Seedling from Oldenburg. Medium to large, roundish oblate; skin bright yellow, striped and splashed with dark red; flesh white, tender, juicy, subacid; very hardy, stands intense cold. January to May.

Rhode Island Greening. Large, roundish, oblate; skin green, becoming a greenish yellow when ripe; flesh yellow, fine-grained, tender, juicy, with a rich, acid flavor; succeeds well at the North, but not valuable here, dropping its fruit too early. October to December.

Roxbury Russet. Rather above medium size, roundish, oblate, remotely conical; skin covered with russet; flesh greenish white, rather granular, slightly crisp, with a good subacid flavor. November to January.

Romanite, or Carthouse. Medium size, roundish, oblong; striped and shaded with deep red on greenish yellow ground; flesh yellow, firm, juicy and rich, becoming tender and sprightly in the spring; valuable for the South; an early and profuse bearer and a good keeper. January to May.

Royal Limber Twig. Very large, pale yellow, blushed or striped with red; flesh juicy, rich and very good; tree a thrifty grower, and bears well. December to March.

Rawle's Genet. Tree moderately vigorous, putting forth its leaves and blossoms much later than other varieties in the spring, consequently avoiding injury by late frosts: it is, therefore, particularly valuable for the South and Southwest. Fruit medium size, roundish, approaching oblong ; color pale red, distinctly striped on yellow ground; flesh nearly white, fine, rich, mild subacid, fine texture, crisp, juicy, compact, a profuse bearer. One of the most popular winter Apples South and West. January to April.

Rome Beauty. Large, yellow, striped and mixed with light red; flesh yellow, breaking coarse-grained, subacid; valuable for market on account of its productiveness, size and beauty, as well as for its certain bearing. Noveniber to January. Can always be depended upon for a full crop.

Salome. Tree a strong grower; equals Wealtly in hardiness; holds its fruit firmly, even against strong wind-storms; an early and annual bearer, although a heavier crop on alternate years; fruit of medium and uniform size; quality very good, which it retains even into summer; keeps well with ordinary care until July, and has been kept in excellent condition until October.

Se ek - no - Further (Westfield). Medium to large ; slightly russeted, with dull red stripes; tender, rich, spicy and fine. Good bearer. November to February. 


\section{Fruit and Ornamental Trees, Shrubs, Etc.}

WINTER APPLES, continued

Smith's Cider. Rather large; greenish white, striped with red; flesh tender, juicy, with a mild, subacid flavor; a prodigious bearer and profitable market variety. December to February.

Shockley. From Jackson Co., Ga. Fruit medium size, yellow, with crimson cheek; flesh subacid, nearly sweet; tree erect, vigorous grower; comes into bearing early, and is exceedingly productive. This is probably the most reliable and valuable winter variety for the South, and is there justly very popular; valuable in eastern Virginia and lower Maryland. Keeps till May or June.

Sutton's Beauty. From Mass achusetts. Large, handsome, roundish; skin yellow; waxen. striped with crimson; flesh tender, subacid; tree strong grower and bears well; a valuable new market Apple. December to January.

Stark. A western kind of first quality; thoroughly tested and always valuable, especially for market. The tree is a very strong grower, hardy and bears annually; much in demand, and planted on a large scale; fruit large, oblong, partly covered with red; flavor mild subacid. Deserves a place well up among "best kinds ;" long keeper.

Stayman's Winesap. J. W. Kerr, of Denton, Md., says: "It is one of the finest Apples under cultivation-so much superior to its parent, the old Winesap, in size, flavor, color and keeping qualities as to completely crowd it out where both are known. It originated with Dr. Stayman, of Kansas, and was in bearing with me ten years ago. Its merits were so strongly pronounced from the first as to warrant strong commendation. From my oldest trees specimens have been exhibited at county fairs and horticultural meetings, and sent to many pomologists and prominent growers. It is now attracting attention everywhere as a profitable market variety. It has large size, bright red color, great productiveness and best quality to recommend it. The tree is a vigorous grower, and, like its parent, is irregular and drooping in habit, and adapts itself readily to different soils and situations. Truly it is a great Apple."

Twenty Ounce (Cayuga Red-Streak). Very large and showy, roundish, uneven; greenish yellow, splashed and marbled with dull red; flesh is good, sprightly, though not high-flavored, coarse-grained; its size and regular bearing make it popular. October to January.

Talman's Sweet. Medium size; pale yellow, tinged with red; flesh rich and of first quality, and a good cooker. December to April.
Virginia Beauty. Very popular in southwest Virginia, where it has been grown for the past thirty years or more. Medium to large; very dark red; subacid. Very valuable on account of its fine keeping qualities. 


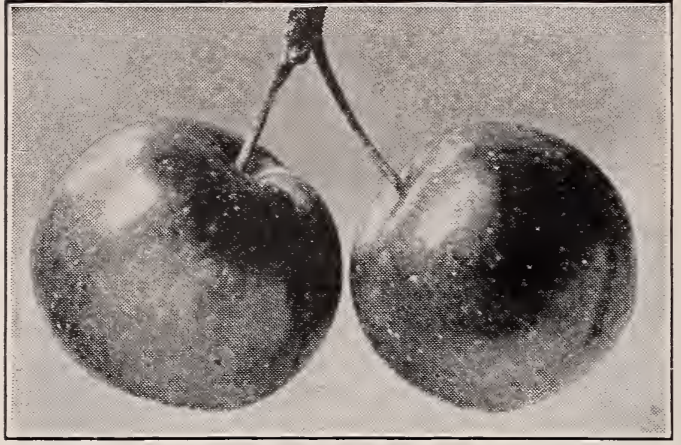

HYSLOP CRAB APPLE

WINTER APPLES, continued

ion we have of this fruit, possessing, as it does, a combination of so many excellent qualities. For cider it has but few equals; for the table it stands amongst the best; for keeping it is justly esteemed; and for bearing it scarcely has a riral. Considering all this, we most earnestly recommend it to the consideration of orchardists. Fruit medium size, rather oblong; skin smooth, of a fine, dark red, with a few streaks and a little 5ellow ground appearing on the shady side; flesh yellow, firm, crisp, with a rich, high flaror. December to April.

Yates. A Georgia rariety; of small size, dark red and dotted with white dots: flesh firm, juicy, aromatic; immense bearer and good keeper.

\section{CRAB APPLES}

\section{For Ornament or Preserving}

General Grant. Very large, round, dark red: flesh white and tender; excellent for dessert. September.
Hewes' Virginia Crab. A famous cider Apple; immensely productive; fruit small, striped; Hesh firm, yellowish, juicy; flaror acid, rich; musk rery heary; cider can be kept in a sweet state for a long time; should be in erery orchard from which a barrel of cider is intended to be made. Oct. to Dec.

Hyslop Crab. Fruit large for its class; produced in clusters; dark rich red, corered with a thick blue bloom; good for culinary uses and for cider.

Red Siberian Crab. Quite small-a little orer an inch in diameter; nearly round, with a brilliant scarlet cheek, on a pale, clear. waxen yellow ground: stalk rery long and slender; tree rery productire, and bears when rery young; quite ornamental; good for preserving. September to October.

Transcendent Crab. Fruit large for its class; golden rellow, with a beautiful, rich crimson cheek: when ripe, the red or crimson nearly covers the fruit; flesh creamr yellow, crisp, subacid, pleasant and agreeable. This is truly a beautiful fruit; tree a rapid grower and productire. September.

Whitney. (No. 20.) Large; striped and splashed. with red; flesh yellow to white, firm and juicy, with a pleasant subacid flaror; tree rery hards, rigorous, and productive. August.

Yellow Siberian Crab. Resembles the red crab except in color, which is of a fine, rich yellow. This is equally good for preserving, and considering the beautiful habit of the tree, the rich, showy bloom, together with its attractire appearance when corered witl fruit, we think it highly deserring of a place amongst the ornamentals.

\section{Varieties best suited to Tidewater Virginia and Eastern- and Western-shore Maryland}

American Summer

Bough

Carolina June

Early Harrest

Buckingham

Bonum

Fallawater

Benoni

Ben Daris

Berry Red

Delaware Late Tinter Johnson's Fine Winter Jonathan

\section{SCMMER VARIETIES}

Early Ripe

Fourth of July

Grarenstein

Horse

FOR LATE SCMNER AND ACTLMN

Gravenstein

Jefferis

Maiden's Blush

FOR LATE AUTCMN AND WINTER

Kinnard's Choice

Lankford's Seedling

Lady Apple

Manimoth Black Twig

Nickajack

Royal Limbertwig
Red Astrachan

Starr

Yellow Transparent

Oldenburg

Wealthy

Romanite, or Carthouse Shockley

Starman's Winesap

Smith's Cider

Tinesap

\section{Varieties best suited to Piedmont, Virginia} SCMMER VARIETIES

Amer. Summer Pearmain Bough

Benoni

Carolina Red June
Early Harrest

Early Ripe

Gravenstein
Red Astrachan

Starr

Yellow Transparent 
VARIETIES BEST SUITED TO PIEDMONT, VIRGINIA, continued FOR LATE SCMMER AND AUTUMN

Buckingham

Bonum

Duchess of Oldenburg

Albermarle Pippin

Ben Davis

Fallawater

Gano

Grimes' Golden

Johnson's Fine Winter

Jonathan
Jefferis

Maiden's Blush

Smokehouse

Wealthy
FOR LATE AUTUMN AND WINTER -

Kinnard's Choice

Lady Apple

Mammoth Black Twig

Nickajack

Paradise Winter Sweet

Rawle's Genet

Romanite, or Carthouse
Rome Beauty

Royal Limbertwig

Smith's Cider

Stayman's Winesap

Shockley

Winesap

\section{Varieties for the Valley of Virginia and West Virginia and Western Maryland} SCMMER VARIETIES

Amer. Summer Pearmain

Bough

Benoni

Buckingham

Duchess of Oldenburg

Albemarle Pippin
Baldwin
Bonum
Ben Davis
Delaware Late Winter
Fallawater

Carolina Red June

Early Ripe

Early Harvest

Jefferis

FOR LATE SUMMER AND AUTUMN

Fall Pippin

Fallawater

Gravenstein

FOR LATE AUTUMN AND WINTER

Gano

Grimes' Golden

Jonathan

Johnson's Fine Winter

Kinnard's Choice

Lady Apple

Mammoth Black Twig
Red Astrachan

Starr

Yellow Transparent

Maiden's Blush

Smokehouse

Paradise Winter Sweet

Rawle's Genet

Rome Beauty

Royal Limbertwig

Stayman's Winesap

Winesap

\section{Varieties best suited to Pennsylvania and the West}

Early Harvest

Early Ripe

Buckingham

Bonum

Fall Pippin

Baldwin

Ben Davis

Dominie

Gano

Caroline Red June

Early Ripe

Buckingham

Bonum

Ben Davis

Berry Red

Johnson's Fine Winter

Jonathan

Kinnard's Choice
SUMMER VARIETIES

Fourth of July

Jefferis

Red Astrachan

FOR LATE SUMMER AND AUTUMN
Fallawater
Gravenstein
Maiden's Blush

FOR LATE AUTUMN AND WINTER

Grimes' Golden

Johnson's Fine Winter

Jonathan

Kinnard's Choice

Mammoth Black Twig

Varieties best suited to the South

SUMMER VARIETIES

Early Harrest

Fourth of July

Horse

FOR LATE SUMMER AND ACTUMN
Fall Pippin
Gravenstein
Oldenburg
Wealthy

FOR LATE AUTUIN AND WINTER

Lankford Seedling

Mammoth Black Twig

Nickajack

Romanite

Royal Limbertwig
Starr

Yellow Transparent

Oldenburg

Smokehouse

Wealthy

Northern Spy

Rome Beauty

Smith's Cider

Stayman's Winesap

Starr

Yellow Transparent

Shockley

Stayman's Winesap

Winesap

Yates 


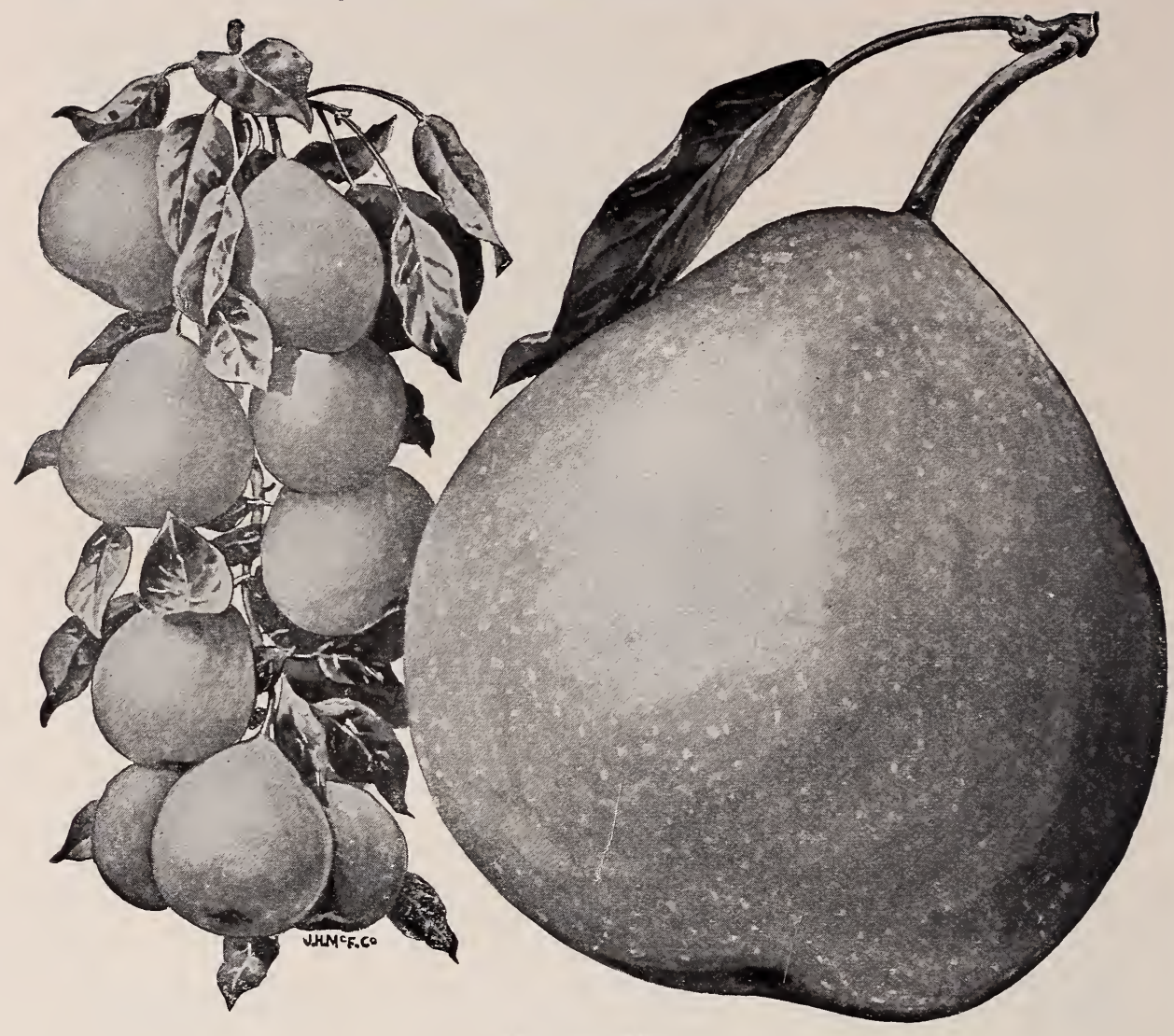

KOONCE PEARS

\section{SELECT PEARS}

The Pear succeeds on most soils, but does best on heavy soil. STANDARD trees are produced by budding or grafting on its own stock. These are best adapted for large orchards. DwARFs are produced by budding on quince. These are best suited for small grounds and gardens. They should be planted deep, a few inches below the bud. Pears should be well cultivated when young. Gather the fruit about two weeks before fully ripe.

\section{SUMMER PEARS}

Bartlett. Large; yellow, with a soft blush on the sunny side; flesh white, exceedingly fine-grained and buttery, sweet, very juicy, with a highly perfumed vinous flavor. This is justly esteemed one of the very best Pears in cultivation, and deserves a place in every collection; bears early and well. July and August.

Clapp's Favorite. A first-rate early variety, which is rapidly growing in favor; resembles the Bartlett in appearance, but ripens a week or ten days earlier; one of the best native sorts. Fruit large; skin smooth, yellowish green, becoming yellow, dotted and shaded with red next the sun: flesh yellowish white, juicy and melting; of very good quality. Last of July.
Comet, or Lawson. This Pear is now attracting a good deal of attention, and promises to be a profitable sort for the early market. The tree is a vigorous grower and very productive; fruit above medium size, and of most beautiful crimson color, on yellow ground; flesh crisp and pleasant, though not of best quality. Ripens early in July.

Early Harvest. Fruit medium size; skin pale yellow at maturity, with blush next to sun; flesh white, tender, sweet; among the best of its season. July.

Koonce. Origin, Illinois. Early, highly recommended; good bearer; said to be frostproof and free from blight; vigorous grower; fruit handsome. (See cut above.)

LeConte. Supposed to be a hybrid between the old Chinese Sand Pear and a culti- 
SUMMER PEARS, continued

vated variety. Fruit large, pyriform; skin smooth; tree of remarkable vigor and rapid growth; foliage luxuriant; has so far been nearly free from bliglit; commences to bear early, and is extremely prolific; fruit ships well, and has been sold in the Boston and New York markets at very high prices; quality variable. Probably no new variety of fruit has ever attracted so much attention in the South as this. Ripens a few days before Bartlett. Grown only as a standard.

Manning's Elizabeth. Fruit small, yellow, with a lively red cheek; flesh white, juicy and very melting, sweet and sprightly. Tree hardy and exceedingly productive. We regard this as one of the most valuable early dessert Pears, and should be in every collection. Season, Angust.

Wilder. A beautiful early Pear, bellshaped, yellow with slight blush; flesh yellow, fine-grained, subacid; does not rot at the core. Tree vigorous and bears young. July.

\section{AUTUMN PEARS}

Angouleme (Duchesse d'Angouleme). Very large, dull greenish yellow, streaked and spotted with russet; flesh white, buttery and very juicy, with a rich and very excellent flavor; on young standard trees the fruit is variable, but on the quince, to which stock this variety seems well adapted, it is always fine. The large size and fine appearance of this fruit make it a general favorite. September to November.

Anjou (Beurre d'Anjou). Large, greenish, sprinkled with russet, sometimes shaded with dull crimson; flesh whitish, buttery, melting, witl a high, rich vinous, excellent flavor; very productive; succeeds well on the quince; should be in every orchard. October and November.

Bar-Seckel (Columbia). A cross between Bartlett and Seckel combining the best qualities of each. Tree vigorous, hardy and productive. Fruit good size. Rich quality, high color, handsome and good. Sept. and October.

Blight Proof. This ironclad against blight is indeed an arquisition. It seems to have inherited all the health and vigor of its parent, the Sand Pear; the fruit is large to very large, conical, smooth, with beautiful greenish yellow surface; flesh is tender and very juicy; the tree is an upright, strong and handsome grower; bears young and enormously. Should be in every collection where a good fruit and annual bearer is desired. First-rate for market. August and Sept.

Flemish Beauty. Large ; skin pale yellow, but mostly covered with marblings and patches of light russet, becoming reddish brown at maturity on the sunny side; flesh yellowish white, not fine-grained, but juicy, melting, saccharine and rich. In good soils and open situations the Flemish Beauty, when in perfection, is one of the most superb Pears; the tree is hardy, and bears early and abundantly. The fruit should be gathered sooner

\author{
(and
}

than most Pears, and ripened in the house; they are then always fine; otherwise often poor. September.

Garber. A seedling of the Japan Hybrid, raised by Dr. J. B. Garber, of Pennsylvania; resembles Kieffer, yet is larger, of better quality and very productive, and especially valuable for canning. Tree a strong grower, bears early and abundantly. "Bound to win favor for market." Free from blight. September and October.

Howell. Rather large, light waxen yellow, often with a finely shaded cheek, and covered with dots and patches of russet; flesh white, rather coarse and granular, with a rich, perfumed, aromatic flavor; a profuse bearer. August.

Japan Golden Russet. From Japan, and remarkable in many ways. The fruit is round or apple-shaped, very regular and uniform; of good size, 8 or 10 inches around and becomes a handsome golden russet color, hanging in clusters. The tree is a luxuriant grower with an abundance of thick, tough, leathery foliage, enabling it to endure great heat and drought without jnjury. It is an extremely early bearer and bear's enormously every year. Ripens in September.

Kieffer (Kieffer's Hybrid). A new variety originated near Philadelphia, and supposed to be a cross between the Chinese Sand Pear and the Bartlett. Tree a very vigorous grower and an early and abundant bearer. Fruit medium to large; skin yellow, with a bright vermilion cheek; flesh brittle, very juicy, of good quality; valuable for market or family use; succeeds best as a standard. September.

Rossney. Ripens two weeks after Bartlett; large; excellent keeper and shipper; uniform size, shape and color; handsome, 


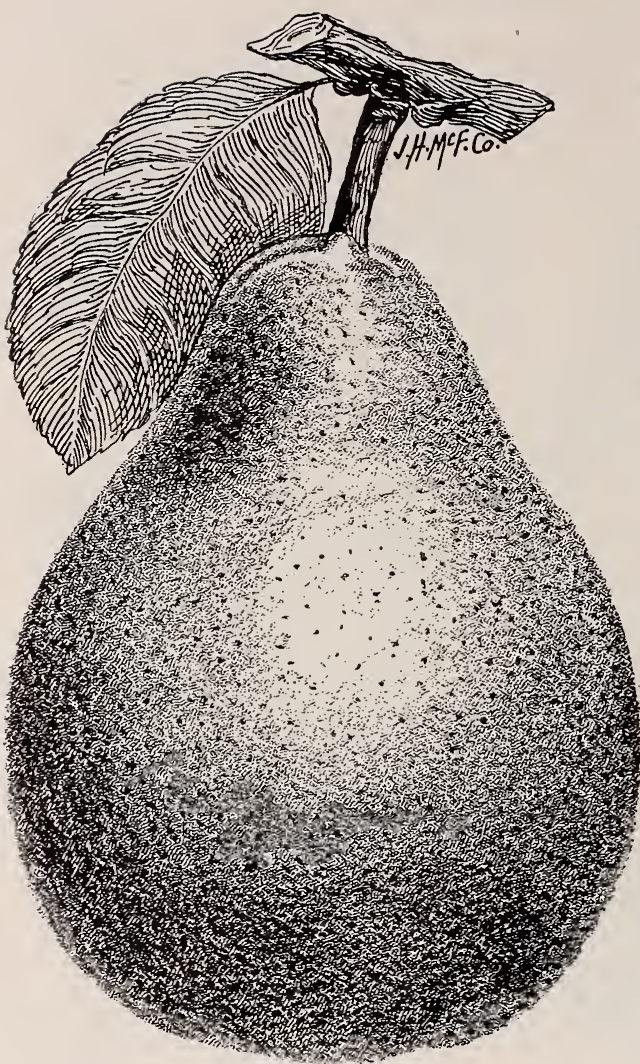

LAWRENCE PEAR

AUTUMN PEARS, continued

creamy skin, with blush; melting, juicy, sweet and superior flavor. Tree a strong grower, hardy and productive. Its recommendations are its fine quality, large size and form and good shipping qualities.

Sheldon. Medium size; yellow on greenish russet, with a richly shaded cheek; flesh a little coarse, melting, juicy, with a very brisk, vinous, highly perfumed flavor; productive. Grown only as a standard. Oct.

Seckel. Small; skin brownish green at first, becoming dull yellowish brown, with a lively russet-red cheek; flesh whitish, buttery, juicy and melting, with a peculiarly rich, spicy flavor and aroma. This variety is pro- nounced by good judges the richest and most exquisitely flavored Pear known, and we may add that the tree is the healthiest and hardiest of all Pear trees, forming a compact and symmetrical head, and bearing regular and abundant crops at the ends of the brancles. In view of all this, it is easy to see that we consider no collection complete without it. It ripens gradually from the middle of August to the middle of September.

Vermont Beauty. In color it is a rich yellow, with a beautiful bright carmine cheek. The fruit is of medium size and the flesh is of the finest quality, being rich, juicy and aromatic. The tree is a fine grower, of very thrifty habit and perfectly hardy. Its season of ripening, which is after the Seckel and before the winter Pears are ripe, makes it particularly valuable.

Worden Seckel. A seedling of the Seckel, equally good in flavor and quality, but far superior in size, color and beauty. It is an upright grower, abundant bearer; ripens a little later than Seckel. Originated in Oswego county, N. Y. Introduced by Smith \& Powell Co., Syracuse, N. Y.

\section{WINTER PEARS}

Lawrence. Rather large: yellow, covered with brown dots; flesh whitish, slightly granular, sometimes buttery, with a very rich, aromatic flavor; unsurpassed amongst the early winter Pears; succeeds well on the quince; ripens with little care; should be in every orchard; tree healthy, hardy and productive. November and December.

Lincoln Coreless. As its name implies, it is entirely seedless; no seeds or core whatever. In season it is late, and the keeping qualities of this Pear are extraordinary. Specimens have been known to keep in an ordinary cellar until March. In size it is very large, single specimens having weighed from one to one and one-half pounds. The trees are strong, healthy growers, enabling them to hold the fruit well; in growth equal to the Kieffer. The quality of the fruit is excellent, there being no core; the Pear is one solid mass of rich, luscious, juicy fruit, which is pronounced perfect by all who taste it. When ripe they are mellow; color a golden tint, and possessed of a rich aromatic flavor. The flesh is yellow and the quality of the best.

Winter Nelis. Medium size; dull russet; flesh yellowish white, fine-grained, buttery and melting; abounding with juice of a rich, saccharine, aromatic flavor; the tree is a slender, straggling grower, but a good bearer. November and December.

To aid the inexperienced in making their selections, we have carefully prepared the following lists, - one for cultivation as standards on Pear stocks, the other to be grown as dwarfs on the quince root.

Anjou

Angouleme

Bartlett

Blight Proof

Clapp's Favorite

Anjou

Angouleme

Clapp's Favorite
FOR STANDARDS

Flemish Beauty
Garber
Harvest
Howell
Koonce

Flemish Beauty

Howell

Koonce
Kieffer

Le Conte

Lawrence

Manning's Elizabeth

Seckel

FOR DWARFS

Lawrence

Manning's Elizabeth
Sheldon

Vermont Beauty

Worden Seckel

Wilder

Seckel

Sheldon 


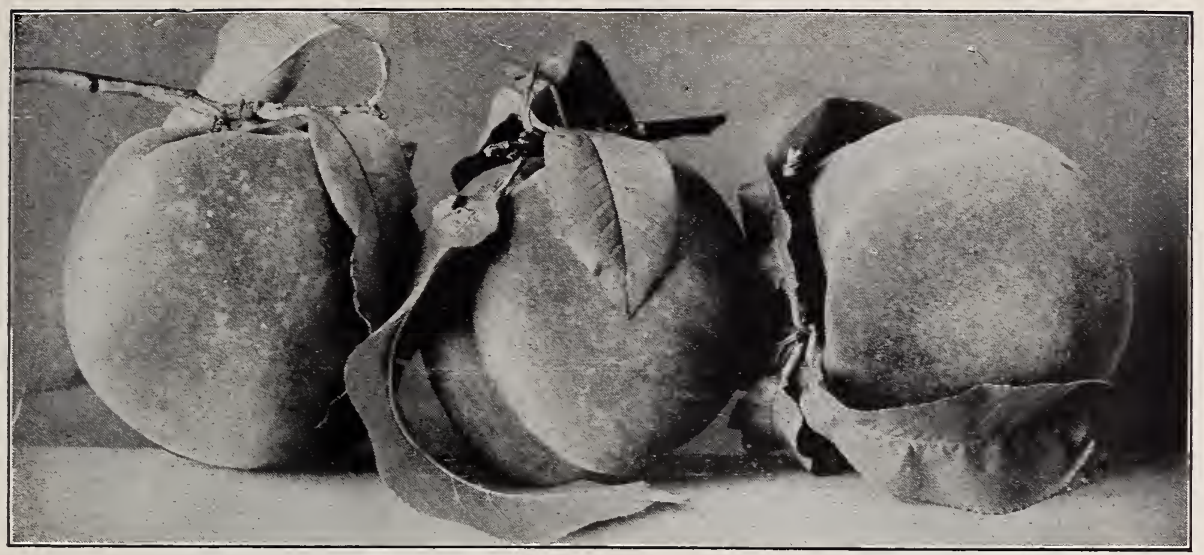

\section{SELECT PEACHES}

The Peach when in perfection is one of the most delicious of all fruits. It succeeds in farorable localities from Maine to California. The trees are of shorter duration than most fruit trees of temperate climates, but on account of their being more easily grown and in shorter time than other fruits are consequently cheaper. Everybody can afford to plant a few, and the orchardist, if his soil is at all adapted to their culture, will find them more profitable than almost anything that can be grown on the same land. We have revised our list so as to include only well-known and tried rarieties. Our aim is to grow the best stock, not the cheapest. We bud from healthy vigorous stock only, and our trees are absolutely free of yellows, San José Scale and other injurious insects, as Certificate of Inspection will show.

Admiral Dewey. This is a perfect freestone; ripens with the Triumph; flesh is yellow, of uniform color and texture to the pit. Has better form and brighter color on the surface; is equally hardy and productice. The tree is a strong, symmetrical grower, and as near perfection as we can obtain in a single variety. Specimens sent us from Georgia were received in perfect condition, and were all that Mr. Husted claims for them. We beliere there is no doubt about its being the very hest early yellow freestone in cultivation. June.

Alexander. One of the earliest Peaches. Fruit medium size, nearly corered with crimson; flesh white and good; raluable market rariety South; bears rery young. June.

Amsden (Amsden's June). This rariety originated on the farm of L. C. Anisden. near Carthage, Mo., fruiting for the first time in 1872. It first fruited for us on our grounds at Richmond in 1877 , ripening June 26 , or more than two weeks in adrance of Hale's Early. Tree hardy, healthy and vigorous, and a great bearer: fruit full, medium size, roundish; skin nearly corered with light and dark red, almost purplish in the sun, somewhat mottled in the shade; flesh greenish white, white at the stone, juicy, sweet, slightly rinous and rery good; has prored quite profitable South for the early market. This fills the place of Alexander, Bower's Early, Governor Garland, Wilder and severai other sorts, all of which are very similar to it in appearance, time of ripening and general characteristics.
Argyle Elberta. New. The originator says, "It is a strain of Elberta that has $1.0 t$ been degenerated by years of propagation from the nursery row. The original trees are about 16 vears old; there are about 17 of them, and they made about six crates of Peaches per tree last year. It is superior to the common Elberta in the following points: It has a stronger constitution, eridenced by a dark green, healthy-looking foliage, and abundant production of fruit. There is no record of but one total failure to produce fruit, and that was in 1899-everything failed then. The fruit is of finer color, redder, has better flavor, and keeps better. Seems to be more resistant to rot, as you would expect the fruit on a rigorous tree to be. It is a little later than the common Elberta, ripening four to six dars after it erery vear. One of its finest qualities is that it has fine color before it is ripe, enabling it to present a much finer appearance in the northern markets. I hare a young two-year-old orchard of the Argyle Elberta that hare some fruit this year, notwithstanding the freeze. I ceased to propagate the common Elberta four years ago."

Bilyeu's Late. Originated in Caroline county, Md. A rery late Peach, ripening in October, after Smock Free and Salway. Fruit of large size; color white, with a beautiful blush cheek; flesh white; freestone, and an excellent shipper.

Brandywine. A Peach closely resembling Crawford's Late in appearance, but ripening ten days later, and fully as large. Flesh yellow; freestone. Last of August. 


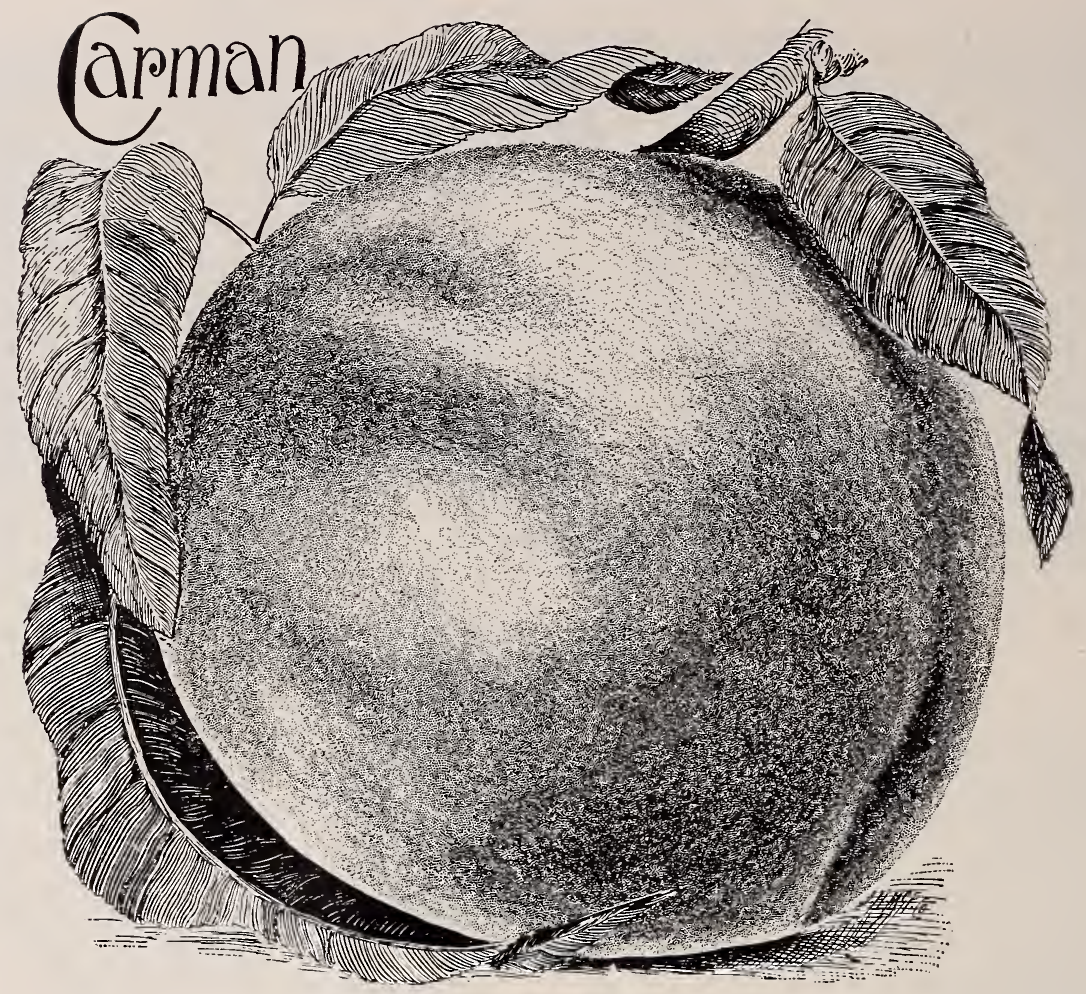

\section{PEACHES, continued}

Butler's Late. This magnificent new freestone Peach originated in the garden of J. T. Butler, Richmond, Va. Fruit of the very largest size; skin greenish white, with red cheek; flesh white, firm and of very good flavor; tree vigorous and very productive. This promises to be a very valuable sort, owing to its combination of many valuable qualities, among which are very large size, great productiveness and very late ripening, coming in after Smock, when there is usually a dearth of Peaches. First to middle of Oct.

Briggs' Red May. About medium; very highly colored; flesh greenish white, very juicy, vinous and of very good quality; adheres somewhat to the stone: of firm texture. and proves good as a shipping Peach; tree very prolific. Middle to end of July.

Bokara No.3. The hardiest yellow Peach yet brought to notice; of fine quality and a heavy bearer; 30 per' cent hardier than any other kind. August.

Belle of Georgia. Very large; skin white, with red cheek; flesh white, firm and of excellent flavor; the fruit is uniformly large and showy; tree a rapid grower and very prolific. A seedling of Chinese Cling, originated by Mr. Lewis A. Rumph, Marshallville, Ga. New. Ripe July 1 to 15.

Beer's Smock. Large, yellow, oblong; similar to the Smork, but larger; also a few days later; flesh firm and red next the seed; one of the very best; freestone. October 1.
Carman. In this new, hardy, rot-proof Peach, ripening at same time as Early Rivers, and yet almost as large and fine as Elberta itself, we have a Peach of great market value; a large, roundish Peach, with pale yellow skin, red blush on summy side; white flesh, tender and melting; rich, sweet and of superior flavor; by far the finest of any Peach ripening middle of July. The nurseryman wlo fails to propagate the Carman will soon learn his mistake. A big, early, yellowskinned Peach of high quality is sure to be in great demand. Don't miss the Carman!

Champion. This new Jeach comes from Illinois, recommended as an ironclad against frost, as in 1890 , when there was a total failure of the Peach erop, it bore heavily. It has stood a temperature of $18^{\circ}$ below zero, and bore well the following season. Fruit is of large size; skin ereamy white, with red cheek; the flesh is white, rich and juicy; a perfect freestone and good shipper. July.

Chair's Choice. Originated in Anne Arundel county, Md. Fruit of very large size, yellow, with a red cheek: flesh yellow, firm and of good quality; tree a strong grower and a good bearer. Ripens just before Smock. Early September.

Christiana. A new, very large, fine-looking yellow Peach, ripening between Crawford's Late and Smock. Its large size, handsome appearance and time of ripening combine to make it a very valuable Peach. Last of August. 


\section{Fruit and Ornamental Trees, Shrubs, Etc.}

\section{PEACHE.S, continued}

Chinese Cling. Fruit large, roundish, oval; skin transparent cream color. with inarbling of red next to the sun: flesh creamy white, very juicy and melting, with it rich, agreeable flavor. Last of July.

Chinese Free. Seedling of Chinese Cling. Large, oblong; skin white, with red cheek; flesh firm and well-flarored; free from rot; valuable for market. August.

Columbia (Yellow Indian, Pace, etc.). Large; skin rough and thick, dull, dingy red, with streaks of darker red; flesh yellow, illterspersed with red or pink. Last of August.

Connet's Southern Early. A seedling of the old Chinese Cling, which originated in Guilford county, N. C. It has extra-large fruit of a cream-white shade, having a beautiful blush next the sun. It is one of the most delicately colored Peaches grown, and a clear freestone, with small seed. Of fine quality, and borne in profusion early in July upon trees noted for their strength and vigor.

Mr. IT. G. Balsley, of Greensbore, N. C., in the year 1889 planted a seed of Connet's Southern Early, and in the year 1893 the tree was loaded with as fine Peaches as any one need wish to see. The season being a rainy one, and the little tree loaled down with fruit (as the Peaches had not been thinned out, every one that was set was allowed to mature), one would naturally suppose there would be a great many rotten Peaches, but there was lot a rotten Peach on the tree-not eren a specked one. Ouly one showed signs of decay, and it had been bruised in hunting for soft Peaches.

Crawford's Early. A magnificent large yellow Peach of good quality ; tree exceedingly rigorous and productive; its size and beauty make it one of the most popular or chard fruits; flesh very juicy, rich, slightly subacid, of good flavor; raluable as a market variety; freestone. First of August.

Crawford's Late. A superb fruit of rery large size; skin yellow, with a broad, dark red cheek : flesh deep yellow, but red at the stone, juicy and melting, with a very rich and excellent rinous flavor. This is undoubtedly one of the very best yellow Peaches, and an admirable market fruit; tree vigorous and productive; freestone. Middle of August.

Crosby. (Excelsior Frost Proof). This valuable Peach has been tested for ten years in the bleakest parts of New England, and in e a cli case lias proved itself to be firstclass in every way. In 1886 and 1890 , when there was a total failure of the Peach crop, from the late frost, the Crosby bore its regular heavy crop. Being almost frost-proof, it should be planced generally. The fruit is medium size, bright yellow, splashed and streaked with carmine on the sumny side; the flesh is firm, sweet and delicious; stone very small; an eliormous bearer. It ripens early in August.

Early Canada. Originated in the Prov ince of Ontario Medium size, good quality and handsome appearance. One of the earliest varieties, and vearer freestone than most of the early sorts. July.

Elberta. An exceedingly large, high-colored yellow Peach; a cross between Crawford's and Chinese Cling. Juicy, well-flavored. Said to be probably the finest yellow freestone in existence. Ripens early in August.

Emma. Fruit very large; skin golden rellow, with red cheek; flesh yellow, finegrained, firm, juicy and highly flarored. Tree a luxuriant grower and quite prolific: a perfect freestone. One of our most attractive and profitable market rarieties. Ripe July 25 to August 5 .

Engle's Mammoth. Large; yellow. Resembles Crawford's Late. Middle of Oct.

Everbearing. W. T. Nichols, of Obion county, says of this variety: "The parent tree is said to have produced its first crop about 1888 . The tree ripens fruit continuously from about August 1 to October 1 . The best specimens on the parent tree at twelve rears old measured twelre inches in circunference; skin creamy white, with a deep blush in the sun; clingstone." A rariety that will bear on one tree fruit for two months, liaving during all that time ripe fruit to be gatlered, is one that every lover of fruit will desire on account of its novelty.

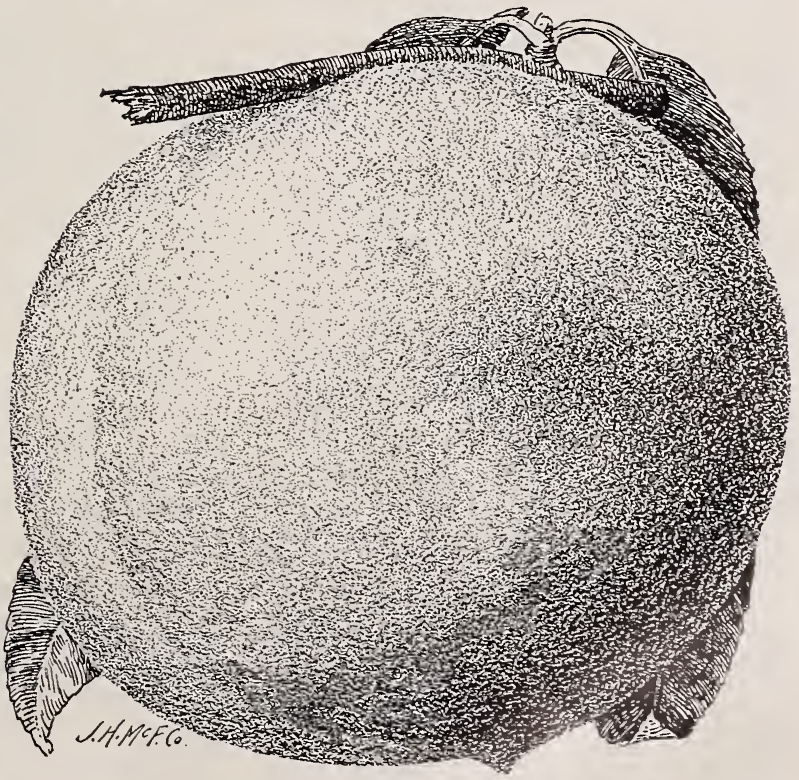

CHAMPION (See preceding page) 


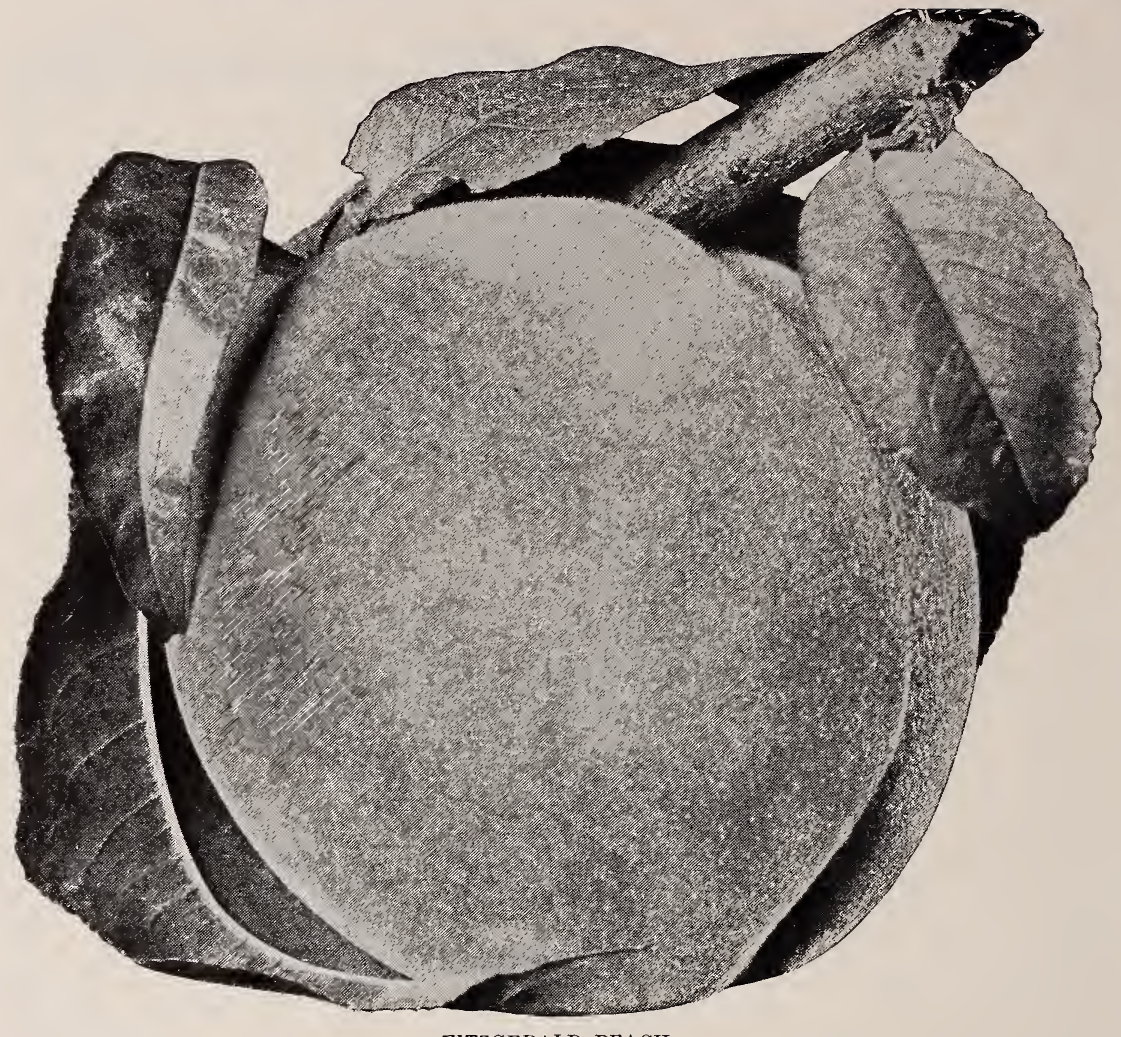

FITZGERALD PEACH

PEACHES, continued

Fitzgerald. An improved Early Crawford, being fully equal to it in size, quality and color. In Canada and Michigan it has proven one of the hardiest. Fruit large; brilliant color, bright yellow, suffused with red; flesh deep yellow, best quality. Early September. The originator says: "Fully realizing that there are too many varieties of fruit placed upon the market, with no special merit, adds to our pride and pleasure in being able to offer in the Fitzgerald Peach something that' $h$ is intrinsic worth and many points in its favor ahead of any other variety that has of late years been introduced. The Fitzgerald Peach is a chance seedling found at Oakville, Ontario, fully outside the Peach belt of Canarla, and in a section where Peachgrowing as a business can never be profitably engaged in. This tree was first brought to our notice by one of our traveling salesmen. We watched it three years, in which it fruited abundantly, and that, too, in seasons when the Peach crop was a failure in the favored Niagara district. The fruit is of very large size, exceeding that of the Early Crawford. Its quality is infinitely superior, while as a cropper it far excels the Crawford in every way, and most other varieties. One strong point is the smallness of the pit, being the smallest of that of any Peach that we know of. The location in which it was found dem- onstrates its hardiness, and it has another strong quality of fruiting very early."

Ford's Late (Chinese Strain). Large ; white, with carmine to the sun; flesh white, juicy. One of the best; freestone. Oct.

Foster. A new, very large Peach resembling Crawford's Early in appearance, but is larger and somewhat earlier. Tree hardy and productive. First of August.

Fox's Seedling. Large; skin white, with a red cheek; flesh melting, sweet and good. Desirable for canning or marketing. First of September.

Globe. Origin, Pennsylvania. Tree a rapid grower and an enormous bearer; large; golden yellow, with a red blush; flesh firm, sweet and delicious; uniformly large; freestone. September 20 to October 1 .

Gold Drop. Large, fine quality, handsome and hardy; valuable for market. A Michigan favorite; freestone. September.

General Lee. Seedling of Chinese Cling. Of same description, ten days earlier, and less inclined to rot; clingstone. July 29.

Geary's Hold-On. Large, yellow Peach, seedling of the Smock; fruit large; pale lemon-yellow. Ripens a little later than the Smock. Last of September.

Greensboro. Larger and earlier than Alexander; colored beautifully with crimson 


\section{PEACHES, continued}

or yellowish cast; many specimens measure 8 to 9 inches in circumference; flavor pronounced by some equal to an August Peach. Originated from seed of Connet's Southern Early. Will be a fine market Peach. June.

Grand Admirable Cling. Full merlium size; skin white, nearly corered with red. A very handsome and excellent Peacli, and a good bearer. First of August.

Golden Dwarf (Van Burens'). This very distinct and attractive variety originated in Georgia. The tree is of diminutive growth, sellom attaining more than 4 or j feet in height; foliage dense, which it retains until quite late in the season. Fruit large; skin yellow, with a red cheek; flesh yellow, subacid, adhering firmly to the stone. Quite hardy and free from disease. Ripens last of September.

Heath Freestone. A fine Peach. Fruit large; skin. white; flesh juicy, rather tender, with a good flavor. Beginning of Sept.

Heath Cling. This is, perhaps, the very best of the late clingstone Peaches. Its very large size, beautiful appearance, high and luscious flavor, combined with its late macurity, and the long time it may be kept after taken from the tree, render it a most raluable sort for market. Fruit rery large; skin pale yellowish white, with a faint blush or tinge of red in the sun; Hesh greenish white, very tender and melting, exceedingly juicy, with a sweet, rich, high and luscious flavor. Tree hardy and vigorous. Middle of September, and sometimes keeps a month after taken from the tree.

Hiley. Belle of Georgia and Elberta, twin sisters, and children of the old Chinese Free, are without doubt the two most popular Peaches of their season in America today. Hiley, a seedling of Belle, when it becomes generally known and planted, will take rank close up alongside of the two named above, and on account of its earliness is far more profitable than either. Hiley is a variety of great size and beauty, ripening two or three weeks before its parent. Tree a moderate grower, fruit-buds extremely hardy; fruit of large size and much resembles the Belle, only being more highly colored on the sunny side. Perfect freestone, a long keeper and superb shipper, ripening a week or more ahead of Mountain Rose. Being of such large size, exquisite color and as fine a shipper as the best of the later rarieties, it has for the past three seasons sold for more money than any other Peach I grow, and I have taken thousands of trees of other good rarieties and budded them orer to Hiley; I couldn't wait for young trees to grow up to fruiting. Take my word for it-don't miss planting the Hiley; it is a money-maker, sure! July.

Hyne's Surprise. A very early Peach of good quality; highly colored; similar to Waterloo, but earlier. June.

Hill's Chili. A great favorite for market in the cold northwest, on account of its extreme hardiness and heary bearing. Fruit medium size, oblong; skin yellow, shaded with dark red; flesh yellow, very rich and sweet; freestone. October 1.
Holderbaum. Originated in Pennsylvania. The introducers make wonderful claims as to its immense size, iron-clad hardiness and productiveness. Fruit extra large, light creamy yellow. A beautiful red cheek, small pit; flesh light sellow, streaked with red, extra quality, firm texture. Early Sept.

Iron Mountain. A large, white-fleshed freestone Peach, ripening at about the same time as Bray's Rare Ripe, which it resembles. It is a very popular market Peach in northern New Jersey. Last of August.

Jennings. Originated in Richmond, Va. It is one of the finest, largest and handsomest yellow Peaches we have seen. The Baltimore "Sun" of Aug. 20, 1903, says: "A specimen of this Peach was exhibited at our office, which weighed a pound and measured twelve inches in circumference each way, and was without a visible flaw or blemish." It is a new seedling, fruited for the first time; freestone. August.

Kalamazoo. Mr. R. Morrill, President of the Michigan State Horticultural Society, says of this variety: "Originated in Kalamazoo, attracted attention by bearing regular crops of large fruit of highest quality in a locality where the Peach is considered a failure. A wonderfully strong grower, bears full loads of fruit at two years old, sets an enormous amount of fruit. My trees shed a large portion soon after bloon falls, but so far (four crops) have required some thinning. Size equals Early Crawford, more uniform, pit small, flesh thick, yellow, superb quality. Skin golden yellow, with light crimson cheek; fewest culls of any rariety I erer saw. Kalamazoo, Lewis and Gold Drop are our moneymakers, fully as reliable as a potato crop and grown as cheaply, bushel for bushel. Ripens between Early and Late Crawford." Aug.

Large Red Rareripe. A most excellent Peach, ripening early in August. Fruit large; skin greenish white, dotted, and with a beautiful, rich red cheek; flesh white, red at the stone, melting and juicy, with a sweet and rich flavor.

Large Early York. Is rather large and a beautiful Peach, well worthy a place in every good collection. The tree is vigorous and productive; fruit dotted with red in the shade, deep red cheek to the sun; flesh nearly white, fine-grained, very juicy, with a mild, rich, excellent flavor: a very valuable sort. July 25.

Lemon Cling. A very large and beautiful lemon shaped variety; light vellow, reddened in the sun; flesh firm, yellow, rich, with a vinous, subacid flavor; fine for preserving; tree very hardy and productive. Last of August.

Lemon Free. The name is rery appropriate, as it is almost lemon-shaped, being longer than broad, pointed at the apex, color a pale lemon when ripe. This magnificent yellow Peach originated in Summit county, Ohio, and has proved itself to be hardier than any other good Peach grown in that section. It is of large size, quality excellent, sweet and rich. Exceedingly productive. It is the surest yielder of any variety we have ret grown, never as yet failing to give a crop in the most unfarorable season. September. 


\section{PEACHES, continued}

Levy's Late (Henrietta). A new late clingstone, which originated in the garden of W. W. Levy, Washington, D. C. Fruit large, roundish; skin deep yellow, a shade of rich brownish red in the sun; flesh deep yellow, rather firm, juicy, half-melting, sweet; good and a valuable variety. First to last of Oct.

Lewis Seedling. One of the earliest freestones; white with red cheek; medium to large size. Middle of August.

Lorentz. Its introducer says of it: "IVe have never known it to fail a crop in the most adverse seasons, and we believe it to be as nearly frost-proof as any variety yet introduced. It bears crops when others fail entirely. Fruit is unusually large and of a superior flavor, especially so for one so late in the season. It is a freestone, yellowfleshed, and its handsome appearance has been a surprise to all who have seen it. It bears enormously, one foot of wood cut for photographing having as many as twentyfive Peaches on it, and frequently requiring thinning from over-production. We feel confident that this is the best late Peach ever introduced, and that this belief will be shared by those who grow it. Does not crack; is very firm; keeps well, and is a fine shipper." Ripens last of September.

Mamie Ross. Seedling of Chinese Cling, which it resembles; fruit almost as large as its parent; white, neariy covered with carmine; flesh white, juicy, good quality; a regular and prolific bearer. Is popular throughout the South as the finest early cling. June.

Mary's Choice, Yellow. Blushed with red; large to very large. A fine Peacli and should be planted extensively. Freestone. August.

Mary's Choice, Red. Freestone. Extra large and fine Peach; one of the best Peaches; should be planted in every orchard. August.

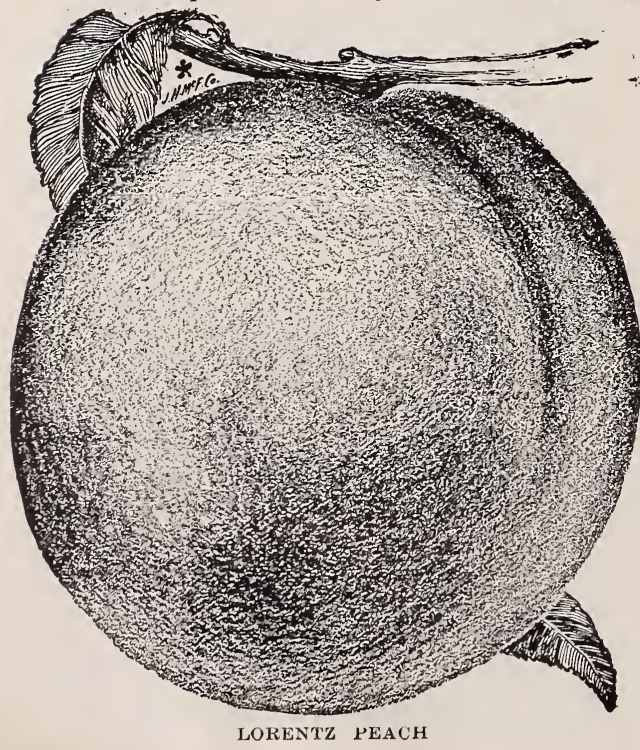

Mathew's Beauty. A seedling from Randolph county, Ga. The original tree has been fruiting for eight years and missed but one crop; is being largely planted as the most valuable succession to Elberta yet introduced. Its bearing and shipping qualities are fully equal to Elberta-it is a size larger, superior in quality, ripens about three weeks later. Perfect freestone; skin golden yellow, streaked with red; flesh yellow, firm, of excellent quality. Probably the best market Peach since Elberta was introduced. September.

McCallister. Large yellow freestone of first quality. September.

Michigan Early. A western variety which has given great satisfaction. Splendid as a market Peach, as well as for canning; hardy and prolific.

Moore's Favorite. A handsome large Peach, white with blush to the sun; similar to Oldmixon, but a few days later; flesh white, tender and juicy; rery desirable. Freestone. August and September.

Mountain Rose. A variety of very great value; very profitable for market, and is steadily growing in favor. Fruit large, roundish; skin whitish, nearly covered with light and dark, rich red; flesh white, slightly stained at the stone, juicy, sweet: separates freely from the stone. Ripens just after Troth's Early.

Morris' White. Rather large ; skin creamy white, tinged with red in the sun; flesh slightly firm, white to the stone, melting and juicy, with an excellent flavor; tree vigorous, and bears fair crops; one of the very best for preserving, on account of the entire absence of red at the stone. August 15.

New Prolific. A vellow freestone, ripening between Crawford Early and Late. From Michigan.

Oldmixon Freestone. Is a fine, large, productive variety, succeeding well in all localities and well deserving of the high favor in which it is held as an orchard variety; skin yellowish white, with deep red cheek; flesh white, but red at the stone, tender, rich, excellent; indispensable. Middle of August.

Oldmixon Clingstone. Large; yellowish white, dotted with red on a red cheek; flesh pale white, very melting and juicy, with an exceedingly rich, luscious flavor; one of the most desirable clingstone Peaches. Middle of August.

Picquet's Late. This very valuable late Peach originated in "Georgia, and has been disseminated over a wide extent of country, and succeeds well generally. It has been planted to a considerable extent in Maryland and Virginia, and has proved a very excellent and profitable sort. Fruit large and handsome; skin yellow, with red cheek; flesh yellow, melting, sweet, and of the highest flavor. We recommend it for its many valuable qualities. Ripens about with Smock.

Rivers (Early Rivers). One of Rivers' seedlings, introduced from England. Large; color pale straw, with a delicate pink cheek; flesh melting, or rather dissolving, with a rich racy flavor; ripens ten days later than Early Beatrice. The best Peach of its season.

Red Cheek Melocoton. A famous old, well-known and popular variety, extensively 


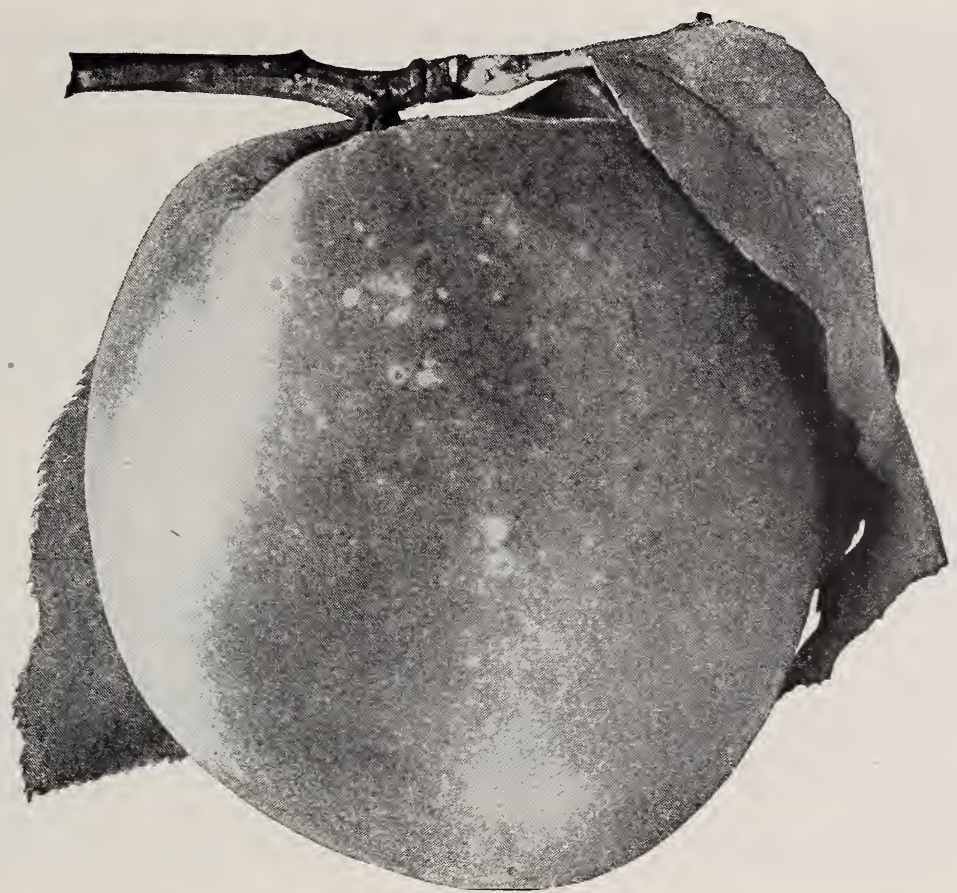

ELBERTA PEACH (See page 19)

PEACHES, continued

cultivated as a market fruit; fruit large; skin yellow, with a deep red cheek; flesh red at the stone, juicy, with a good, rich, vinous flavor; productive; freestone. Middle of Aug.

Reeves' Favorite. Fruit large, roundish, with a fine red cheek; flesh deep yellow, red at stone, juicy, melting, with a good, vinous flavor. One of the largest and handsomest Peaches; should be in every orchard. First of September.

Ringgold Cling. Said to be larger and in every way superior to Heath Cling, with which it ripeus.

Ruding's Late Free (Yellow). We have fruited this variety on our nurseries and consider it one- of the finest large, late, yellow freestones grown. We advise that it be planted extensively. Some specimens measured 9 inches in circumference.

Salway. A large, late, yellow freestone, of English origin; handsomely mottled, with a brownish red cheek; flesh deep yellow, juicy, melting, rich; very productive; a rariety growing more and more in favor with the orchardist. Ripens after Smock. Free.

Smock Free. Rather large, yellow, with a red cheek; flesh yellow, red at the stone; very productive; not of high excellence, but valuable as a market variety. In the Delaware and Maryland peach-growing district this variety is planted perhaps more extensively than any other sort, and large profits have been realized from it. It succeeds well in eastern Virginia, but west of the ridge is not so raluable. Middle to last of September.
Sneed. The originator says: "Sneed has been bearing several years, and has ripened ten days earlier than Alexander. It is a seedling of Chinese Cling, of same high quality, and is the earliest fine Peach known. The fruit is of full medium size, somewhat oral in shape; creamy white, with light red blush; flesh very tender and good." June.

Snow's Orange. Large, yellow; very hardy and productive; valuable for market; fieestone. September.

Steven's Rareripe. Large, oblong; white, nearly covered with red, very highly colored and beautiful; heavy bearer and free from disease; freestone. October 1.

Stump the World. Large; creamy white, with a bright red cheek; flesh white, juicy and high-flavored; very productive; one of the best market varieties. Middle of August.

Susquehanna. A rery handsome and valuable Peach; originated on the banks of the Susquehanna river, in Pennsylvania; a great favorite wherever known. Fruit of the largest size, sometimes measuring twelve inches in circumference; skin rich rellow, with a beautiful red cheek; flesh yellow, juicy, sweet, with a rich, vinous flavor; the best of all the rellow-fleshed Peaches; freestone; a moderate bearer. Augst 25.

Troth's Early. A very early and excellent Peach, of medium size; whitish, with a fine red cheek; flesh juicr, sweet and very good; one of the most popular and profitable varieties for early marketing. We are propagating it largely for that purpose. Middle of July. 


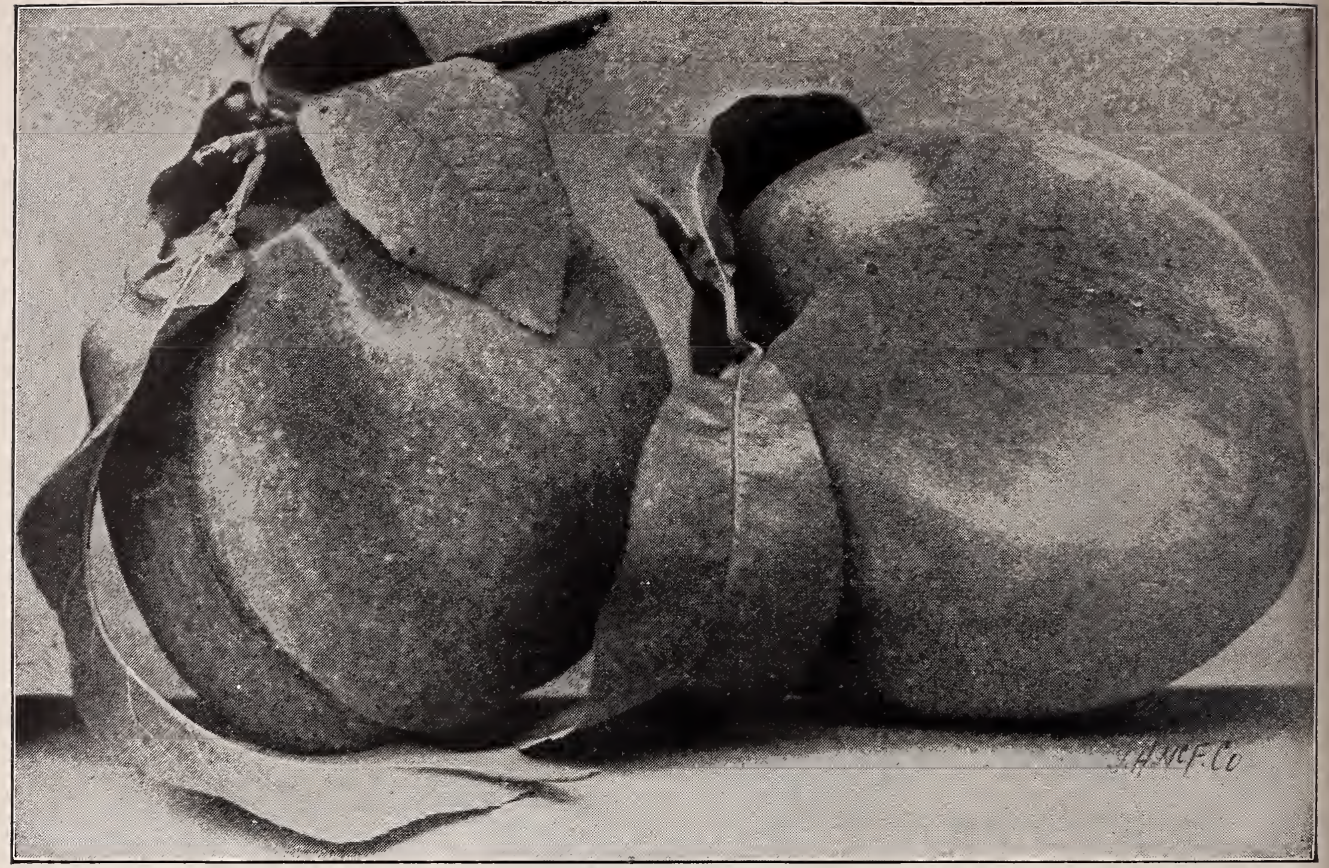

WHEATLAND PEACH

PEACHES, continued

Triumph. Originated in Georgia. Ripens with Alexander; blooms late; has large flowers, and is an abundant bearer. Tree makes a very strong growth; fruit large size, with very small pit; surface is yellow, nearly covered with red and dark crimson in the sun; flesh bright yellow; nearly free when fully ripe; of excellent flavor. This and the Greensboro almost entirely supersede the Alexander and Amsden, and Triumph has especial value as being the earliest yellow Peach. June.

Victor. This is a new, very early variety from Texas. Fruit medium to large, with pleasant subacid flavor; semi-cling. Tree is a vigorous grower, and a heary annual bearer. The originator says it is earlier than sneed, which makes it a valuable variety for the South. Late June.

Waddell. A remarkable new Peach of the North China strain. Tree a heavy, stocky grower, with low spreading habit. Fruit is of medium size, oblong, rich, creamy white. with bright blush on sunny side; skin thick; flesh firm, rich, juicy, sweet and melting when fully ripe; freestone. Ripe early in June. J. H. Hale, the famous Georgia Peach grower, says of it: "I am willing to risk my Peach reputation on the claim that Waddell is the largest, most beautiful, finest flavored, best shipping and longest keeping Peach of its season."

Wager. Large; skin yellow, with a red cheek; flesh yellow, juicy, and of fine flavor; a very certain and abundiant bearer; valuable market sort. Last of August.
Ward's Late. A fine variety, ripening last of August; vigorous and productive; fruit rather large; skin white, with a fine crimson cheek; flesh white, juicy, melting and excellent; raluable for canning and market purposes.

Wheatland. An extensive fruit-grower says: "It is the largest, hardiest, best, most productive and handsoniest of its season, filling a gap just before Crawford's Late, which it excels. Though crowded on the tree, the fruit was all large." This is high praise, and we hope that on further trial it will be found still worthy of it. Early August.

Wilkin's Cling. Supposed to be a seedling of Heath's Cling, but is larger. Ripens with Heath. October.

Wonderful. From New Jersey. Large, almost globular, slightly pointed apex, uniform size and shape; rich golden yellow, partly covered with bright carmine; flesh yellow, rich, high-flavored, firm; freestone. One of the best for shipping. October.

Yellow Rareripe, or Yellow Alberge. One of the earliest of the yellow-fleshed Peaches; fruit of medium size; skin yellow, with a purplish red cheek; flesh yellow, red at the stone, juicy, sweet and pleasant; freestone. July 20.

Yellow St. John (Fleita's St. John). A large, roundish, yellow freestone, ripening a little before Troth's Early; skin orange-yellow, with a deep red cheek: flesh yellow, juicy, sweet and high-flavored. This is the earliest good yellow Peach we have, and must prove a profitable sort for the early market. Early July. 


\section{SELECT PLUMS}

The Plum, like the Pear and other finer fruits, attains its greatest perfection on our heary soil. The curculio, a small, dark brown beetle, often stings the fruit, causing it to drop off; but the following directions, faithfully observed, will secure a good crop of this splendid fruit everywhere.

As soon as the blossoms have fallen, spread two sheets under the tree, and gire the tree a sudden jar by striking a smart blow with a hammer upon the stub of a limb sawed from the tree for the purpose; the insects will drop on the sheet and can be killed. Collect all the fallen fruit and burn or feed to swine. Repeat the operation every day for two or three weeks. It should be done before sunrise.

Bradshaw. Very large, dark violet-red, juicy and good; tree vigorous and very productive. July.

Coe's Golden Drop. One of the largest, most beautiful and valuable of late Plums; light yellow; flesh yellow; firm, rich and sweet; adheres to the stone; productive. Last of August.

German Prune. A raluable Plum, of fair quality for the table, but most esteemed for drying and preserving; fruit long, oval; skin purple, with a thick blue bloom; flesh firm, green, sweet and pleasant; separates from the stone.

Gueii (Blue Magnum Bonum). A large, handsome Plum; flesh yellowish green, rather coarse, sweet and pleasant; valuable for market. September.

General Hand. Very large; skin deep golden yellow; flesh coarse, pale yellow, moderately juicy, sweet and good; tree grows vigorously, and is very productive; separates from the stone. August.

Green Gage. Small, yellowish green; flesh pale green, melting, juicy, very sweet and rich, and unequaled in flavor; one of the richest and best flarored Plums; separates from the stone; growth slow, and young trees are hard to raise in moist localities. August.

Lombard. Medium size; skin delicate violet, dotted thick red; flesh deep yellow, juicy and pleasant. One of the hardiest, most productive and valuable Plums. Succeeds well everywhere, even on light soils. August.

Monarch. Fruit dark purplish blue, covered with a thin bloom, nearly spherical; large, being about 6 inches in circumference. Flesh pale, greenish yellow, partly free from stone, juicy, and with a pleasant flavor. Trees come into bearing very young, and bear abundantly. September.

Moore's Arctic. Originated in Maine, and celebrated for its remarkable hardiness, freedom from curculio, and great bearing qualities. Fruit grows in large clusters ; large, dark purple; Havor fine, both for preservinc and dessert. A long keeper.

Niagara. Very large; reddish purple; a superb Plum; the tree is an erect, strong grower, and bears well; very valuable for home use and market. August.

Prince's Imperial Gage. Rather large; greenish yellow; flesh greenish, juicy, rich and delicious, sometimes adhering to the stone; tree vigorous and rery productive, a single tree near Boston yielding fifty dollars' worth of fruit in one year. This variety is particularly adapted to dry, light soils; valuable. August.
Prince's Yellow Gage. Above medium size; skin yellow; flesh deep yellow, rich, sugary and melting; parts freely from the stone. Its great hardiness and productiveness, joined to its rich, sugary flavor, make this a favorite sort. July 1.

Reine Claude de Bavay. Large, greenish yellow, spotted with red; flesh rather firm, juicy, sugary, rich, of fine quality; adheres slightly to the stone; a vigorous grower, very productive, and a valuable addition to the late varieties. September.

Spaulding. Seedling of some European variety; almost curculio-proof; when injured the wound heals quickly and the fruit ripens perfectly; the fruit is large, yellowish green, sweet and rich, with white bloom; quality excellent; fruit parts from the stone readily; a superb Plum; tree a strong grower and an early and abundant bearer. August 15 .

Shipper's Pride. This raluable new Plum of the Damson type originated in western New York. Large size; purple, firm and sweet; first-class shipper. September.

Shropshire Damson. An improvement on the common Damson, being of the largest size of its class; dark purple; highly esteemed for preserving; tree vigorous and enormously productive. September.

Smith's Orleans. Large; reddish purple, becoming very dark: flesh deep yellow, slightly firm, juicy, rich, nearly first-rate; adheres to the stone; very productive. Aug.

Washington (Bolmar's). Very large; skin yellowish green, often with a pale red blush; flesh yellowish, firm, very sweet and luscious, separating freely from the stone. There is perhaps, not another Plum that stands so high in general estimation in this country as the Washington. Its great size, its beauty and the vigor and hardiness of the tree are qualities which claim for it a place in every good collection. August.

Wild Goose. Medium size; oblong; bright vermilion red; juicy, sweet, of good quality; cling; productive, and nearly proof against the curculio. The most profitable variety for market in the South and deserves more extensive planting there as well as in the Middle states. July.

Yellow Egg (White Magnum Bonum), A very popular fruit on account of its very large size and splendid appearance; its slight acidity renders it valuable for making sweetmeats; skin yellowish, corered with a white bloom; flesh yellow, adhering closely to the stone; rather acid until it becomes very ripe. Last of July. 


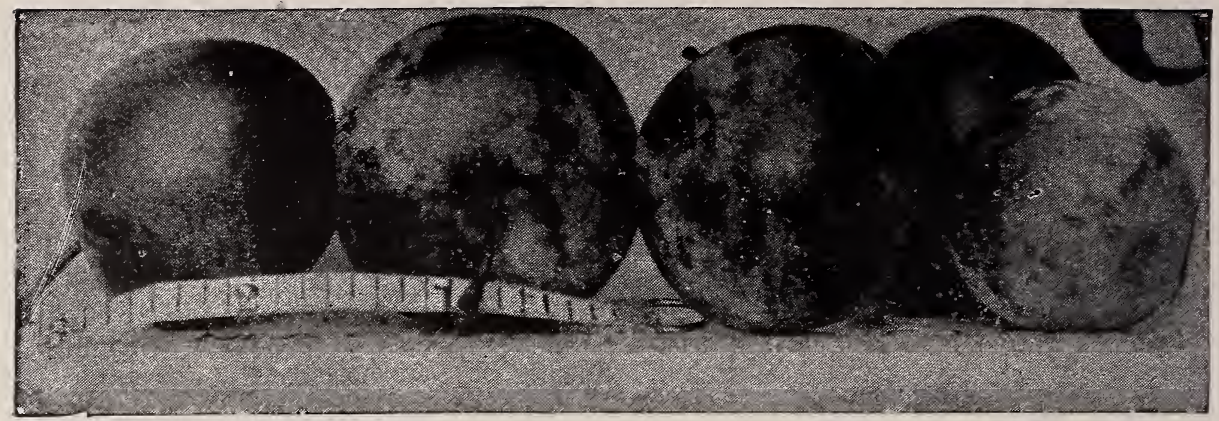

BOTAN, or ABUNDANCE PLUM

\section{JAPANESE PLUMS}

This new strain of Plums has been received with general favor, and in the South, where the European kinds do not succeed as well as at the North, they have proved a blessing. In some sections where the Chickasaw or native kinds (Wild Goose, etc.) only are successful, the Japanese kinds are especially welcome, as they rate up in quality quite well with the very best European varieties. The Japanese Plums, with the exception of one kind, are extremely hardy and vigorous, bearing early and abundantly annual loads of rich luscious fruit, ripening from early in June to September. One very valuable quality of the Japanese Plum is, that the wound made by the curculio (an enemy to Plum culture everywhere), does not seem to affect the Japan kinds to the same extent as European and other kinds; while they are not curculio-proof entirely, yet for some reason the wound soon lieals and the fruit matures perfectly. This may be attiributed to the extremely strong and vigorous nature of both tree and fruit, as it appears to be able to resist and outgrow the trouble.

Botan, or Abundance. Lemon-yellow ground, nearly overspread with elerry, witl heavy bloom; flesh yellow, very juicy; subacid, with apricot flavor; highly perfumed; stone small: the tree is exceedingly hardy and bears regularly; nearly curculio-proof; early and heavy bearer; the best of its class First of August.

Bartlett. Strong upright-growing tree will very glossy dark green foliage; very productive and usually fruits abundantly the second season. Fruit medium size, perfect freestone, dark crimson with flakes and dots of yellow, white bloom; flesh yellow, juicy; quality, flavor and fracrance closely resembling the ever-popular Bartlett pear, but even more delicious; ripens just before Burbank.

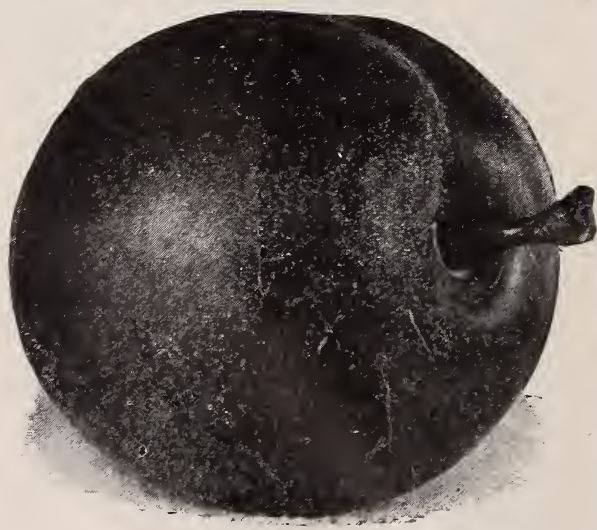

BURBANK PLUM
Probably too soft for long shipments, but all that can be desired for home use and near by.

Burbank. Resembles the Abundance in many ways; globular, large, cherry-red, with sliglit lilac bloom; flesh deep yellow, very sweet, with pleasant and agreeable flavor; strong grower; bears early, often at second year. September 1.

Climax. Mr. Burbank says: "Fruit heartshaped, as large as Wickson and more highly colored; so fragrant that a whole louse is perfumed with a single fruit; delicious as could be desired or imagined, and above all ripens before any other good Plum and nearly a month before Wickson. Tree extremely vigorous, rather upright grower, with strong branches and rery large leares. Productive as Burbank, four or five times as large, two to three weeks earlier and much more highly colored." Mr. Burbank has strong commendations for Climax from such authorities as Professor Van Deman and Professor Waugh, and in all sections where it proves reliable it will be an adrance in many respects upon any Plum now known.

Hale. Originated also by Luther Burbank, who sold the original tree to J. H. Hale for $\$ 500$. Pronounced by Prof. L. H. Bailey, the admitted Plum authority of the country, as "the best in quality of all the Japans." Large. very beautiful, of delicious flavor, and may be successfully slipped long distances. The fruit is clear yellow, nearly covered with bright red; flesh deep yellow, juicy and of rare quality. Tree the most vigorous of all Plums, and a tremendous bearer. This is surely a most promising sort, which no planter can afford to neglect. 
JAPANESE PLUMS, continued

Kelsey. By great odds the best Plum for the South; unfortunately, it is not entirely hardy north of Maryland. After thorough testing it has prored itself to be of first quality in every way; the fruit is large, heart-shaped, golden yellow, sometimes splashed with reddish purple; the flesh is firm, yellow, rich and juicy, with elegant flavor; the pit is small, and parts freely from the flesh; good for home use or shipping. August.

Ogon. Isarge golden vellow, with faint bloom; firm, sweet and of good quality;

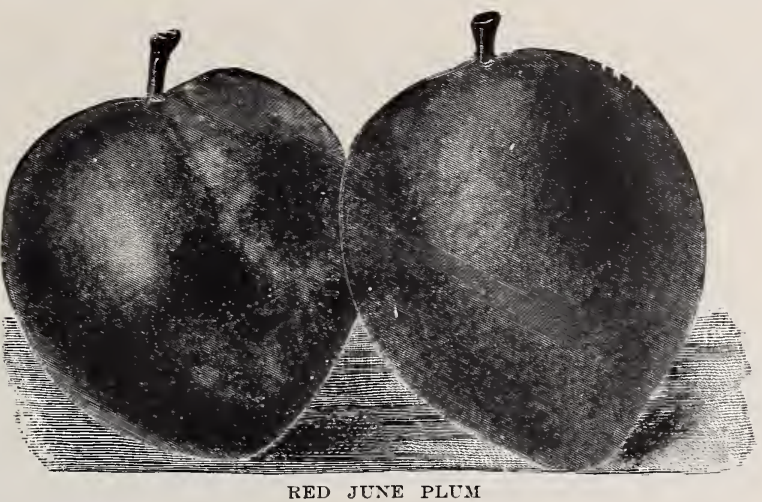

freestone: first-rate for canning; tree vigorous grower. Last of July.

Red June. The great early-market Plum; two weeks earlier than Abundance, and equals Lombard in quality; rery large, bright red; free from rot on account of its early ripening. Tree rigorous and hardy, and should be in erery orchard.

Simonii (Apricot Plum). Origin, China. Fruit large, tomato-shaped, cinnamon-red color; flesh is firm, sweet, aromatic; the flaror is delicious and not found in any other Plum, being similar to that of a pineapple, nectarine and banana; a beautiful and raluable Plum. We believe it has come to stay. Tree a strong grower, bearing young. August.

Satsuma, or Blood Plum. Large, round; skin and flesh dark purplish red, with blue bloom; seed exceedingly small; flesh firm, of good quality, fine flarored; very hardy and strong grower, adapted mainly to the southern states, but does well in the North. Aug.

Shiro. A combination of Robinson, Myrobolan and Wickson. A strong grower, haring

the appearance of a gigantic Mrrobolan in leaf and growth, wood hard and wirr, ripening early in fall; should prove of great value where it is too cold for most of the best sorts. Fruit is produced in profusion, medium to large, clear light yellow with thin white bloom, so transparent the pit can be seen through the flesh, which is firm, juicy, rich, pleasant subacid; ripens two weeks before Burbank and nearly as productire.

Sultan. Professor Van Deman says: "Sultan is my choice of all the new Plums which I hare tested. It is a cross between Wickson and Satsuma; large, being orer two inches in diameter and nearly round in shape. The surface is smooth, dark wine-red or garnet, and very handsome. The flesh is garnet color, too, and rich-looking. In flavor it is excellent, being tart enough, vet not sour, but a delicious subacid. No Plum that I hare eaten is better, and when cooked it could scarcely be equaled. It has all the high flat $r$ r of Satsuma when cooked, and Satsuma has heretofore been rated far above all other Plums for cook-

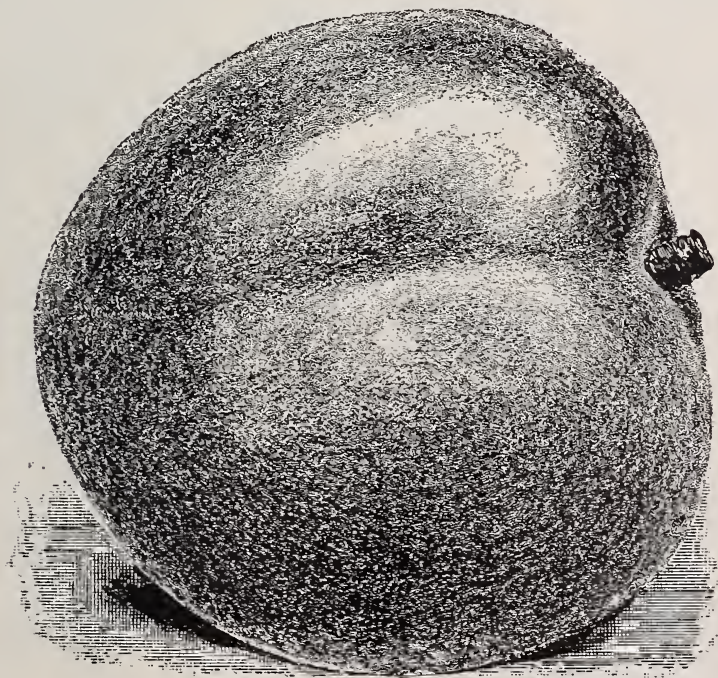

WICKSON PLCM ing. The season of Sultan is at least a month earlier.

Wickson. One of the latest of Mr. Burbank's introductions. The fruit is rery large and of rare beauty. Pearly wnite color, changing to a glowing carmine, with a heary white bloom. The flesh is firm, sugary and delicious; will keep two weeks after ripening. Ripens after Burbank and before Satsuma. This Plum has many good qualities. and should be planted extensively, as it is a valuable market sort.

Willard. Earliest of all the Japan Plums, and hence very raluable for market. A strong, vigorous, hardy tree, rerr productive; fruit medium size. spherical to oblong: bright claret-red, with many minute dots; firm, white flesh, freestone. Terr handsome when well ripened. and will keep a long time. Two weeks earlier that any other kind except Red June. The best rariety for market. 

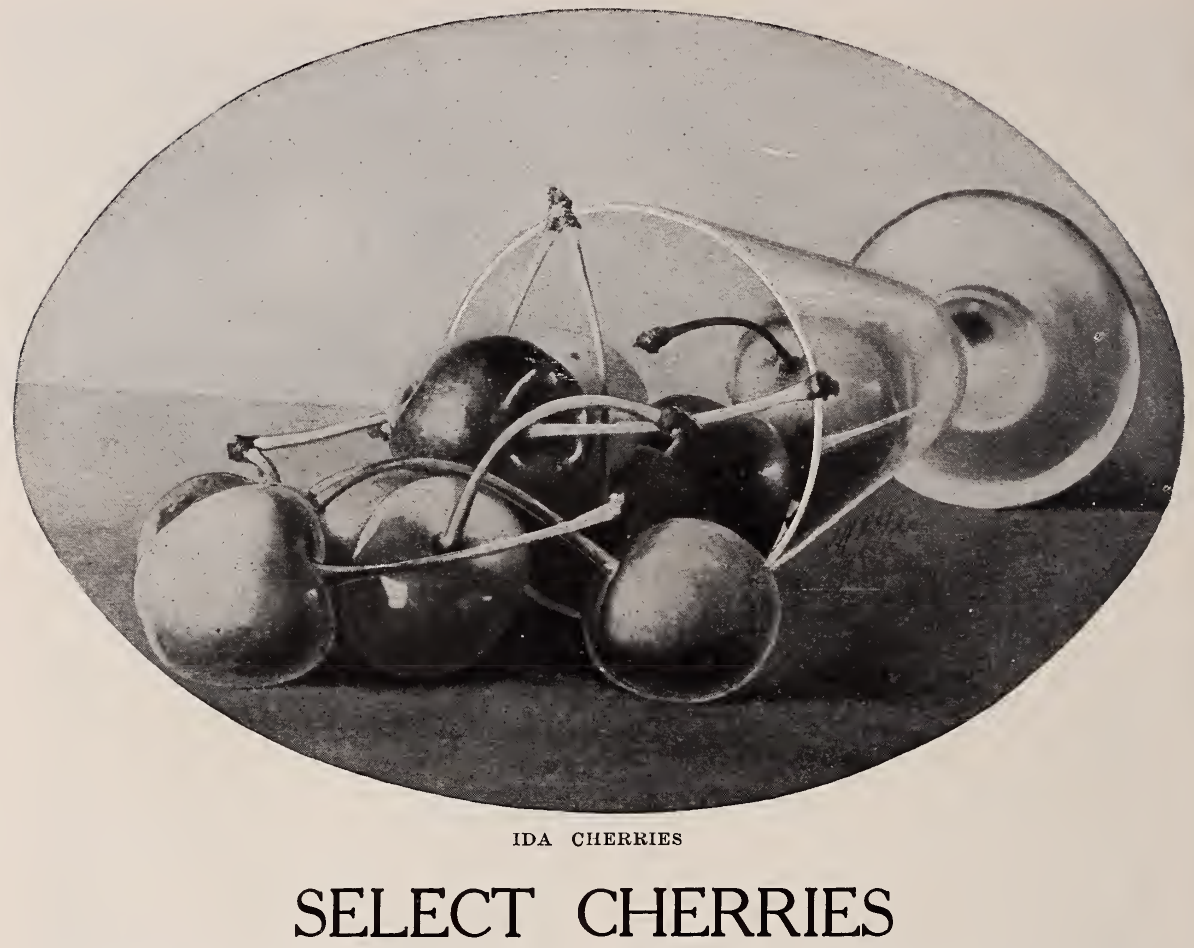

The Cherry succeeds on most soils and in nearly all localities throughout this country, but attains its greatest perfection upon those of a light, gravelly or sandy nature, provided they are in good condition. In planting Hearts and Bigarreaus, avoid wet or damp situations. The Dukes and Morellos will bear more moisture, but will flourish best in a soil that grows the others to the greatest perfection.

\section{HEART AND BIGARREAU}

Bigarreau, or Graffion (Yellow Spanish). Very large, often an inch in diameter; pale yellow, with a handsome light red cheek to the sun; flesh firm, with a fine, rich flavor. This variety, though not of the highest excellence, has become, from its great size, beauty and productiveness, a general favorite. July.

Black Tartarian. Fruit of the largest size, frequently measuring an inch in diameter; flesh dark, half tender, with a peculiar liver-like consistency, rich, nearly destitute of acid, of fine flavor. The vigorous growth and great productiveness of the tree, and the large size and mild, sweet flavor of the fruit, render this variety a general favorite. June.

Black Heart. Rather above medium size; flesh tender, juicy, with a rich, sweet flavor; very productive. June.

Downer's Late Red. Medium size; light red, amber in the shade; flesh tender, melt- ing, rich, with a very high, sweet flavor. A good late sort. July.

Elton. This is certainly one of the finest Cherries, in all respects; its large size, early maturity, beautiful appearance, luscious flavor and productiveness render it universally esteemed; fruit large, pale yellow, blotched and shaded with red; flesh firm, becoming tender, juicy, rich and bigh-flavored; very productive. May and June.

Early Purple. An exceedingly early variety, ripening in May; fruit of medium size; color dark red, becoming purple at maturity : flesh purple, tender, juicy, with a rich and sweet flavor; indispensable as an early variety; productive.

Governor Wood. One of the best of Dr. Kirkland's seedlings, and deserves a place in every good collection. Fruit large; skin light yellow, shaded with bright red; flesh nearly tender, juicy, sweet, rich and delicious; tree vigorous and productive. June.

Ida. This reliable Cherry originated in

"A car of California Cherries sold in New York City during May, 1905, for \$5,342a record price. The Cherries were mostly Black Tartarian and averaged $\$ 235$ per box. The top prices received, however, ran from $\$ 3$ to $\$ 4.25$ a box." From "American Fruits" of August, 1905.-NUFF SED. 
HEART AND BIGARREAU, continued

Pennsylvania several years ago. We consider it worthy of general cultivation for either home use or shipping. Tree vigorous and upright, and an abundant bearer. Fruit rather large; color pale, whitish yellow, more or less mottled with red. Flesh tender, juicy, rich, and of best quality. Seed rery small. Ripens early, ahout May. Should be in every orchard.

Knight's Early. Large ; black ; flesh purple, teuder, juicy, with a very rich, high, excellent flavor. Considered one of the best Cherries in quality; productive. First of June.

Mercer. The Wonderful new Cherry. Introducer says: "It is the finest Heart Cherry that we have ever seen. It is decidedly different from anything before known. It is a very dark red and early. It is one of the most profuse bearers that is grown, and for growth and hardiness it is second to nothing; not even the Mazzard surpasses it. It is larger than the Black Tartarian, and is a finer flavored, and, in fact, is a true Heart Cherry of the finest type. It is a sure cropper. The former owner of the farm has lived on the place since birth and cannot remember a single year when that Cherry did not bear, and for canning it has no equal.

"Another feature of this Cherry is that we hare nerer seen a single Cherry that was wormy, and before we picked the Cherries we called in our neighbors and the universal comment was, 'Isn't that a beautiful sight? and did you ever see anything so full? Aren't they beautiful? Have you any trees of that kind?' Every one's opinion was that it was beyond being beautiful; it was grand and magnificent. But the great recommendation for the Cherry is the extreme hardiness of the tree. 'This tree is the acme of healthy growth, never having a sign of disease in any part of it. The leaves maintain their dark green and the tree continues to grow very late in the season. We do not exaggerate in this description in any way, but give you the plain facts, and are willing to give you at any time proofs that will substantiate what we say of it."

Napoleon Bigarreau. Is one of the best of the firm-fleshed Cherries; it is one of the largest size, often measuring an inch in diameter; well flavored, handsome and productive; skin pale yellow, becoming amber in the shade, richly dotted with deep red, and with a fine marbled, dark crimson cheek; flesh very firm, juicy, with a very good flaror; profitable for marketing. June.

Rockport Bigarreau. Large; deep brilliant red; flesh rather firm, juicy, sweet, rich, with an excellent flavor; a very desirable and profitable Cherry. Beginning of June.

Schmidt's Bigarreau. Very large, deep black; flesh dark, tender, very juicy; fine flavor; productive. July.

Windsor. Origin, Canada; fruit large, liver-colored; flesh firm and of fine quality; tree very hardy; a valuable late variety. July.

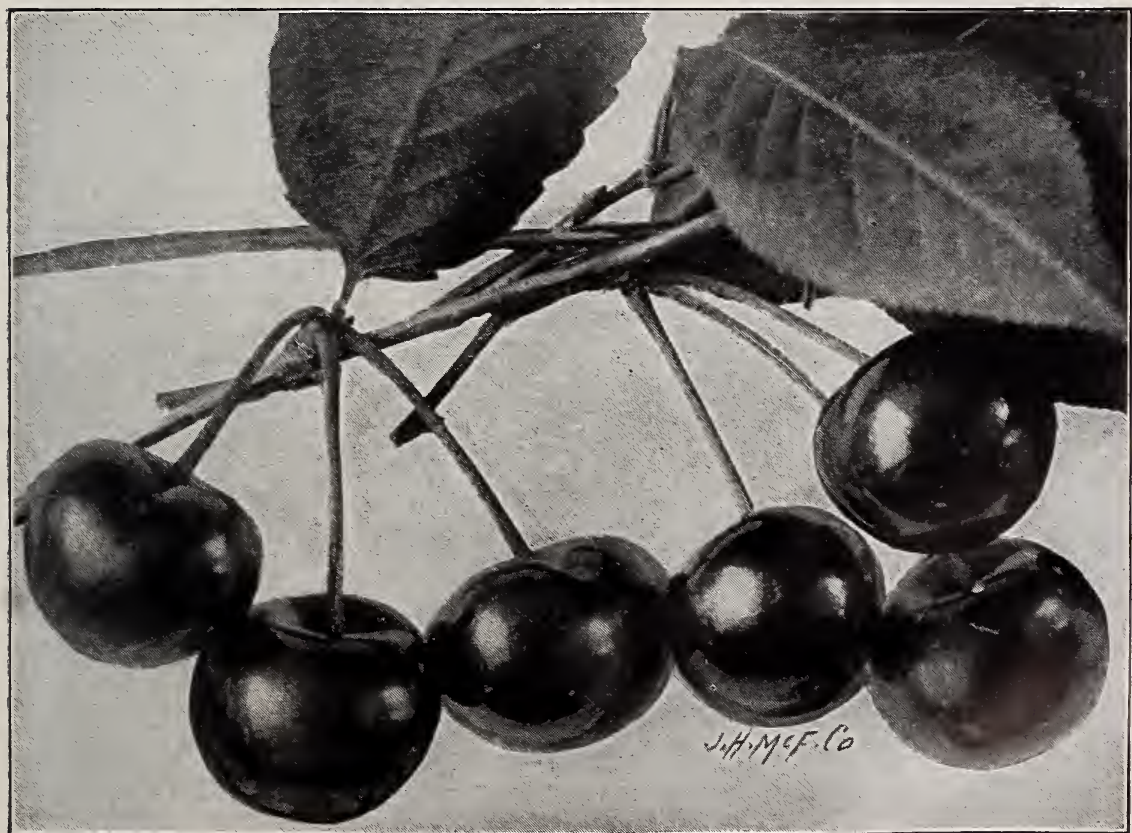

EARLY RICHMOND CHERRIES 


\section{DUKE AND MORELLO}

The Dukes and Morellos are not so vigorous and upright in their growth as the Hearts and Bigarreaus, forming low, spreading heads, with acid or subacid fruit.

Baldwin. 'Tree an upright, vigorous grower, forming a round head; leaves large and broad; bloom pure white, changing to pink; fruit large, almost round, very dark, transparent wine color; flavor slightly acid, yet the sweetest and richest of the Morello type: stems large, of medium length, and generally in pairs. Unexcelled in earliness, vigor, hardiness, quality and productiveness.

Dyehouse. In hardiness and general appearance resembles Early Richmond, but is of finer quality and several days earlier; it produces very regular annual crops; fruit medium; skin bright red, darkened in the sun; flesh soft, juicy, tender, sprightly, subacid, rather rich; resembles both the Morello and Duke in growth, wood and fruit; productive. Superior to Early Richmond.
English Morello. Above medium size; skin dark red, becoming nearly black; flesh juicy, subacid, rich. July.

Early Richmond, or Kentish. Medium size; red; flesh melting, juicy, and at maturity of a rich acid flavor; very productive; fine for cooking. Commences ripening last of May, and hangs long on the tree.

May Duke. Medium size; dark red; melting, rich and juicy; an old and popular sort. Ripens soon after Early Purple Guigne.

Montmorency Large-fruited. Fruit large, and the finest flavored of any in this class; tree a free grower, hardy and prolific.

Montmorency Ordinaire. A beautiful, large, red, acid Cherry; larger than Early Richmond, and fully ten davs later; very prolific and hardy; a variety of great valne; tree a free grower.

Wragg. Tree moderate grower; fruit fair size. Introduced from northern Germany, and recommended as very hardy; flesh rich and dark. July.

\section{SELECT APRICOTS}

This beautiful and excellent fruit needs only to be known to be appreciated. It ripens a month or more before the best early peaches, and partakes largely of their luscious flavor. The tree is even more hardy than the peach, and requires about the same treatment. To make a crop more certain, plant on the north or west side of a wall, fence or building.

Alexander (Russian No. 2). Very large, oblong; yellow, flecked with red; flavor sweet and delicate. July 12.

J. L. Budd (Russian No. 6). Large size; wlıite, with red cheek; sweet and juicy; very fine; the best late variety. August 1.

Early Golden (Dubois' Early Golden). Small; pale orange; flesh orange, juicy and sweet; tree hardy and productive; separates from the stone. Last of June.

Harris. Origin, New York. A new kind of great promise; very hardy; blooms late; a sure bearer; elegant golden yellow color.
Large Early. Large size; orange, with a red cheek; flesh sweet, rich and juicy; separates from the stone; tree vigorous and productive; one of the very best of the early sorts. Last of June.

Moorpark. One of the largest and finest Apricots; yellow, with a red cheek; flesh rather firm, orange, parting from the stone, sweet, juicy and rich, with a luscious flavor. July.

Montgamet (Alberge de Montgamet). Fruit merlium size; skin pale yellow, with a slight tinge of red on the side next to the sun; flesh firm, julcy; one of the best. Early.

\section{SELECT NECTARINES}

The Nectarine requires the same culture, soil and management as the peach, from which its differs only in having a smooth skin like the plum.

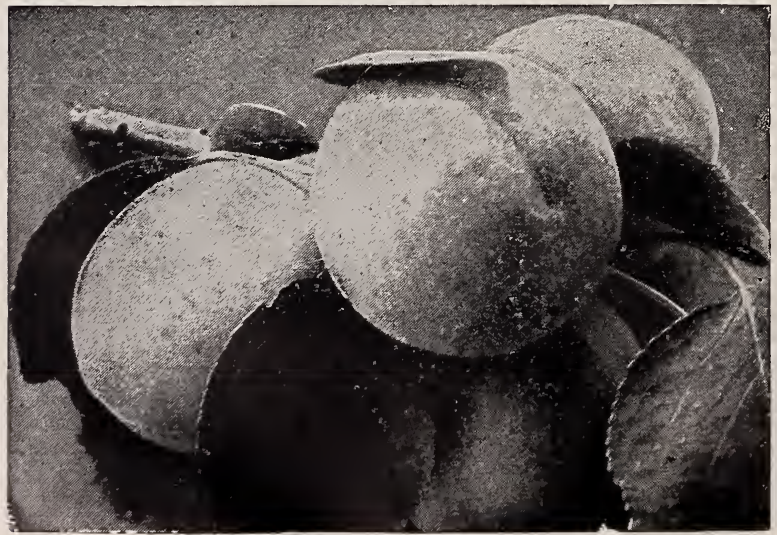

HARRIS APRICOTS
Boston. Large; yellow, red cheek; flesh yellow, sweet and of pleasant flavor; freestone. August

Elruge. Medium size; greenish yellow, with a dark red cheek; flesh pale green to the stone, sometimes stained with red there, melting, very juicy, with a rich, high flavor. This is one of the best and most celebrated of Nectarines; freestone. August.

Pitmaston Orange. Large size; skin rich orange-yellow, with a dark, brownish red cheek; thesh deep yellow, but red at the stone, melting, juicy, rich, sweet and of excellent flavor; freestone; best yellow - fles hed Nectarine. Middle of July. 


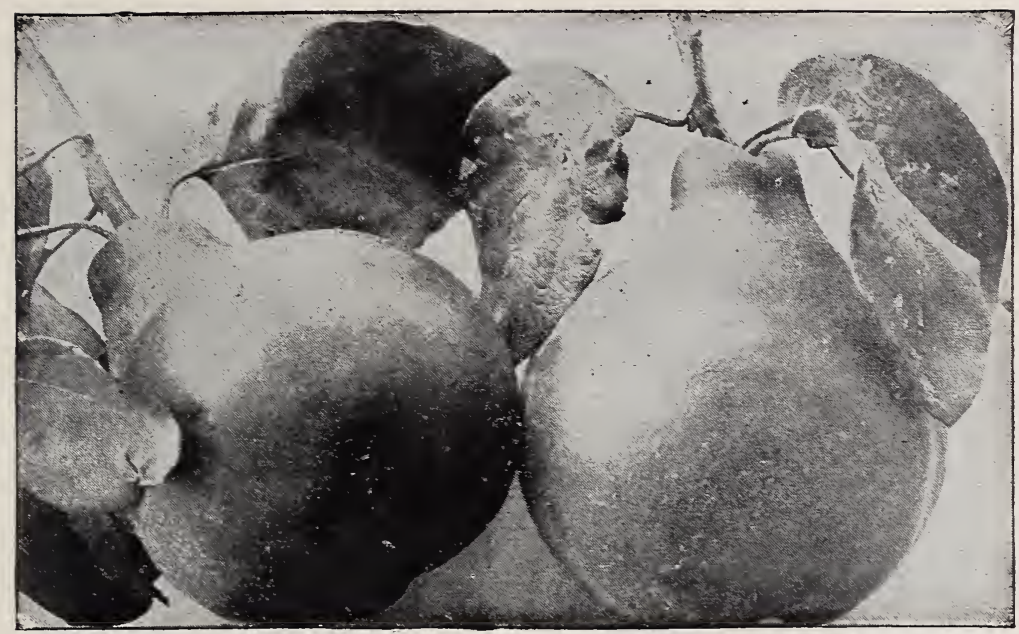

CHAMPION QUINCE

\section{SELECT QUINCES}

From Cornell Agricultural Experiment Station Bulletin, by Prof. L. H. Bailey

"The Quince crop is reliable, and not easily destroyed by capricious rariations in weather. Trees are hardy and productive, easy to prune and spray, and diseases and insects, while rather numerous, are held in check with comparative ease. with the single exception of pearblight. The lands should be retentive of moisture, but not wet and soggy. Good drainage is as essential to Quince culture as it is to the growing of pears or other fruits.

"Quince orchards shouid be giren clean culture. The roots are usually shallow, and very shallow tillage is generally best. Probably the best results will be obtained, in the long run, if the trees are set 14 or 15 feet apart each way."

Bourgeat. Bright golden yellow. The new golden prolific Quince. Pronounced by a responsible grower, who has fruited it for six years, a profuse bearer, of large, handsome. showy, richly colored fruit, that actually keeps like Baldwin apples, in a good cellar, until spring. The core is rery small. Will cook without hardness, like apples. Tree is a robust grower. Origin, France. Ready for use from November through to March or April.

Champion. Greenish yellow; fruit large, distinctly pear form, furrowed about the top. Flesh tender, delicate flaror. Cooks as tender as apples. Tree bears abundantly while roung. In some places it does not ripen well. A good keeper. In a test at Cornell University Agricultural Experiment Station (New York), in 1892-93-94-including Orange, Champion, Rea's and Meech-the Champion areraged the most productive, with Orange a close second. Of American origin. Season late.
Meech's Prolific. Pale, bright orange, with a thin fuzz; fruit large, and in shape ranges from nearly apple shape to short pear shape, somewhat furrowed at the top. Very fragrant, good flaror. Bears young. Productive. Supposed to have originated in Connecticut. Midseason.

Orange. (Apple Quince.) Bright pale orange. The surface only moderately fuzzy. Fruit rariable in size and shape, but in the ideal or original form is distinctly flattened at both ends, like an apple. The most extensirely cultirated of the old rarieties. Ripens after mid-autumn, and keeps until February under good conditions.

Rea. (Rea's Mammoth.) Rich orange, surface very smooth, fruit large to very large, pear form. Flesh of excellent quality. Tree a very strong grower, distinguished by its short stature. Does best under high cultiration. We consider that for orchard purposes, as well as a garden tree, it is very valuable. Origin, Coxsackie, N. Y. Ripens early

\section{Extracts from Letters}

In placing an order with us this spring thes say; "We wish to thank you rers much for the 900 fine yearling trees we bought of sou last spring. They were all beauties and did well: better than trees of any nursery we have erer bought of. Till always deal with $y^{\prime} \cdot u$ and recommend you while you deal thus." - HULL BROTHERS.

I saw the 1,000 York Imperial Apple trees on Sunday, which were purchased of you, and wish to express my appreciation of the manner in which you filled the order. I have never seen any trees that I thought eompared with them. I wish to thank sou rery much for them.-F. S. KIRKPATRICK. 


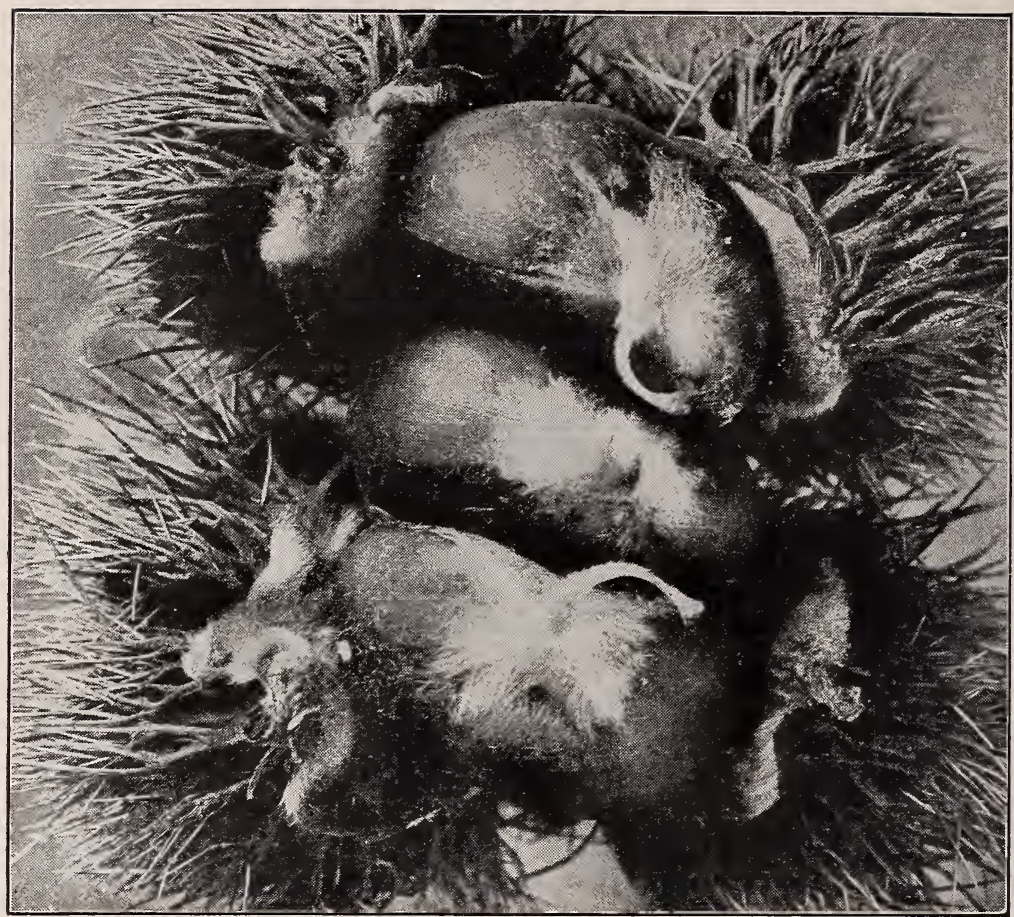

JAPAN CHESTNUTS

\section{NUT-BEARING TREES}

All over the country there is a rapidly growing interest in nut culture. 'The demand for nuts is great; the markets are poorly supplied, and the prices too high. Palatable and wholesome as they are, they should become a common article of food here, as in Europe.

Numerous experiments show plainly that nut culture of nearly every kind can be carried on in the United States with entire success; in fact, statistics plainly prove that a well cared for nut orchard is a "gold mine," indeed.

A large portion of the nuts on our markets are imported. We are sure that, with proper care and culture, we can raise enough to have plenty at home and export largely at paying prices. Most kinds of nuts are planted 30 feet apart, like apple trees, and require about the same general culture.

\section{CHESTNUTS}

\section{AMERICAN (Castanea Americana)}

The well-known native variety; a stately tree, with broader leaves than the European, and producing smaller nuts but a larger quantity of them; both useful and ornamental; the timber is very useful for many purposes.

\section{SPANISH (Castanea Vesca)}

Originally introduced from Asia Minor into Europe; a vigorous grower, and forms a handsome head for lawn planting; a valuable species, both for ornament and fruit; the fruit is much larger than the American rariety; very sweet and excellent when boiled or roasted. Bears early.

\section{GRAFTED VARIETIES}

The Spanish strain ripens after the Japanese. The trees are large-growing, and in planting require more room than the Japanese. There are many profitable varieties of this strain, among the best of which are Numbo, Paragon, Ridgely and Scott. These ripen after the Japanese, and prolong the season well into October.

Numbo. Very hardy; very productive. Comes to bearing quite young. Nuts large and of good quality, ripening early, usually before frost, and selling at high prices.

Paragon. Tree hardy, productive; nuts large and of excellent quality. Two trees 4 years grafted produced one bushel of nuts each, which sold at wholesale at $\$ 10$ per bu. 


\section{SPANISH CHESTNUTS, continued}

Scott. Tree very hardy, strong grower, enormously productive, attaining large size. The original tree measures 5 feet in diameter and produces annually 3 to 5 bushels of large, handsome nuts of excellent quality, that have sold in New York markets at $\$ 16$ to $\$ 18$ per bushel. The Scott trees are very precocions, producing heary crops at 2 years from graft. Another very important feature is its almost entire exemption from attacks of the Chestnut weevil. The original tree stands between two others planted at the same time, both of which have always suffered severely from the Chestnut weevil, while it is the exception to find an imperfect nut on the Scott. Young orchards propagated from the Scott so far appear to be free from worms. The nuts are large, beautiful, glossy mahogany color, free from fuzz, and of good quality, ripening midseason.

Ridgley. A large variety of the Chestnut from Delaware. Very productive. The crop from the original tree is reported to have brought $\$ 32$. Very good quality.

\section{JAPAN (Castanea Japonica)}

Mammoth. This raluable new nut is attracting widespread attention. It claims superiority over all others because it is larger, sweeter, better; bears young and abundantly; like all valuable fruit nowadays, it is necessary to graft to secure and maintain the most reliable kinds; the tree is dwarf in habit, hardy and ornamental.

We grow the following named kinds. Our trees are grafted and are much preferable to seedlings. There are many Japan strains, all of which are early and profitable. As a few are better than many, we will name some ripening in the order named:

Alpha is the first to open. It is large in size, 2 and 3 in a bur, productive; opens September 5 to 10 ; brings the highest market price.

Reliance. A very early bearer; nuts large and uniform; very productive; ripens after Alpha.

Superb. Very productive, running 3 nuts to the bur; ripens after Reliance.

Giant. The largest Chestnut, measuring 7 inches in circumference; smooth, dark, handsome; ripens after Superb.

\section{WALNUTS}

American Black. This is the common native variety. The nuts are excellent and always desirable; besides, the wood is very raluable for many uses.

English. A fine, lofty-growing tree, with a fine spreading head and bearing crops of large and excellent nuts. The fruit in a green state is highly esteemed for pickling, and the great quantity of nuts annually imported and sold here attest to its value; the tree is peculiarly well adapted to the climate of the South, and deserres extensive cultiration.
Japan. Produces in abundance nuts considerably larger than the common hickory nut, which are borne in clusters of 15 to 20 . 'The shell is thicker than the shell of the Eng. lish Walnut, which in a general way it resem. bles, but is not so thick as that of the Black Walnut. The meat is sweet, of the very best quality, and can be removed entire. The tree grows rapidly, and attains a very large size, with a magnificent spreading top. The leaves are of immense size, of a charming shade of green, and very handsome.

Japan, Cordiformis. Differs from Sieboldiana in form of nuts, which are broad, pointed and flattened. Nuts of medium size, shell thinner than Sieboldiana and if cracked longitudinally the kernel can be removed entire. The meat is of good quality. Tree very vigorous grower; attains a great height, has a magnificent head. A rery valuable aquisition. Perfectly hardy. We consider this the best of the Japan Walnuts. Destined to become a valuable nut for market.

Japan, Sieboldiana. A native of the mountains of Japan. Extremely hardy and vigorous grower. Of symmetrical and beautiful form. Three-year-old trees in our nursery hare produced nuts. Wonderfully productive. Nuts produced in clusters of from 12 to 20 nuts each. Shell thicker than that of the English Walnut, but not so thick as that of the Black Walnut. Meat is sweet and of the best quality. The tree has an abundance of fibrous roots and transplants readily.

\section{PECANS}

The common wild native variety found in the South, produced from the seed; bears regular crops of medium size: very salable nuts and good; the tree is rapid-growing and handsome.

Paper-shell Pecan. This is indeed the most valuable nut yet introduced; large, often $11 / 2$ inches in length; thin shell; the kernels are very large, rich, sweet and delicious; enormous profits have been received from the culture of this nut; many thousand trees are being planted, and soon the nut industry, especially of the South, will be very large. Hardy in the Middle states.

\section{FILBERTS, or HAZELNUTS}

We have the best English varieties. The nut is medium size, oblong, very sweet; the tree is of bushy habit, growing from 6 to 8 feet high; rery hardy almost everywhere; early and abundant bearer; very satisfactory.

\section{BUTTERNUTS}

A handsome, rapid-growing, luxuriant tropical looking tree; very ornamental and productive; the nuts are something like black walnuts, but longer and flat; the kernel is much sweeter and rich and more delicate; fine flavor.

\section{ALMONDS}

Hard-shell, Soft-shell or Ladies' 


\section{JAPANESE HARDY ORANGE (Citrus trifoliata)}

This valuable new fruit from Japan, after thorough testing, has proved itself entirely hardy in any part of the United States; it has borne regularly here for several years. The fruit, while not to be classed with first-class Florida oranges, is nevertheless attractive and valuable; it is of small size and much like the ordinary orange; the flavor is good, subacid, very sprightly, valuable to use in place of the lemon, and is elegant to preserve; very desirable as an ornamental, and also for hedging.

\section{MULBERRIES}

This fruit is getting very popular, especially South, where it is fine food for hogs and poultry. The tree is also fine for shade, as it grows rapidly and is very hardy.

Downing's Black. Fruit very large, black and subacid; mostly planted North. Fruits about June 1 to middle of July.

Hicks, or Everbearing Black. This variety is very popular South, as the tree is a very rapid grower, bears very young and has a long season, very often from June 1 until the middle of August. Very sweet.

New American. This we consider equal to Downing's in all respects, continuing in bearing fully as long and a hardier tree. Fruit jet black.

Russian. Brought from Russia by the Mennonites. Tree a very hardy and a rapid grower; fine as a shade tree; bears very young and very heavily, but the fruit is of very little value.

White English. Fruit very small and sweet, but not so good as Hicks'.

\section{PERSIMMONS}

\section{AMERICAN PERSIMMON}

A native of the states south of New York. Makes a beautiful ornamental tree, with dark green foliage. Fruit very luscious, if allowed to ripen on the tree, which is late in the fall, after several good frosts.

\section{JAPANESE PERSIMMONS}

By the introduction of the Japanese Per. simmon, we have added one of the most beautiful and luscious fruits, and one that will be greatly appreciated when better known.

The tree is wonderfully productive, and comes into bearing very young; we have had 1-year-old trees reach us late in the spring from Japan, and next season they would bear a profusion of fruit. Trees 3 feet high, standing in nursery rows, have matured 21 specimens, and others, about 5 feet, have borne over 50 . We know of no tree that makes so fine a show in fruit as the Japanese Persimmon.

The trees are not entirely hardy north of the Potomac, though we have had them standing unprotected near Baltimore for five years, where they have borne well, and even came through the severe winters unhurt.

\section{BEST VARIETIES}

Hachiya. Very large, oblong, conical, with sharp point; very showy; diameter $3 \frac{1}{2}$ inches longitudinally and 3 inches transversely; color of skin reddish yellow, with occasional dark spots or blotches, and rings at apex; flesh dark yellow; some seed; astringent until fully ripe, then very good; tree vigorous and shapely.

Tane-Nashi. Very large, roundish conical, pointed, very smooth and symmetrical; diameter 3 inches longitudinally and $3 \frac{1}{2}$ inches transversely; color of skin light yel- low, changing to bright red at full maturity; flesh yellow; generally seedless; astringent until fully ripe, then one of the best.

Tsuru. Longest in proportion to its size, of all the varieties; slender, pointed; diameter $3 \frac{1}{4}$ inches longitudinally and $2 \frac{1}{8}$ inches transversely; color of skin bright red; flesh orange-colored, with darker coloring in immediate vicinity of seeds, which are few; very astringent until ripe, and one of the latest to ripen; a good keeper; and of good quality when fully ripe; tree a heary bearer.

Yeddo-Ichi. Large, oblate; diameter $2 \frac{1}{2}$ inches longitudinally and 3 inches transversely; very smooth and regular in outline, with a slight depression at the end opposite the stem; color of skin a darker red than most varieties; flesh a dark brown color, verging into purple; quite seedy. In quality it is one of the best, being exceedingly rich and sweet, and, like the Hyakume, is good to eat while still hard; tree a heavy bearer and very thrifty.

Yemon. Large, flat, tomato-shaped, somewhat four-sided; diameter $2 \frac{1}{4}$ inches longitudinally and $3 \frac{1}{8}$ inches transversely; skin bright orange-yellow; flesh yellow, generally seedless; quality very fine; tree rather an open grower, with distinct foliage of a light shade.

Zengi. The smallest of all the varieties introduced: round, or roundish oblate; diameter $13 / 4$ inches longitudinally and $23 / 4$ inches transversely; color of skin reddish yellow; flesh very dark, shows black dots and white fibers when cut transversely; very seedy; quality very good, it being edible while still hard, and one of the earliest varieties to ripen; the tree is vigorous and a very good and reliable bearer.

\section{We also grow other varieties.}

\section{Rocky Mountain Cherry}

Improved Dwarf. From the mountains of Colorarlo. Hardy as a Wyoming sage-bush. With its deep green, willow-like leaves, mass of pure white flowers in spring and a load of fruit in summer, it is well worth cultivation for an ornamental shrub. Makes a bush 4 to 5 feet high, usually fruiting in two years, producing large quantities of jet black fruit about the size of English Morello, and ripening after other Cherries are gone. 


\section{SELECT GRAPES}

The cultivation of this fruit is so simple that no one need fail to obtain a good annual crop, if a little care is taken and a proper selection made. When space is limited they can be trained upon fences or orer doorways or arbors. On this account Grape-vines are particularly desirable for planting in city lots or village gardens. If a few rines each of the red, white and black varieties are selected, then as much enjorment-perhaps more-can be obtained from this fruit as any other. When the selection is made to include some of the early rarieties, as well as those that are good for winter keeping, it is possible to hare fresh Grapes upon the table during several months of the year.

The following list contains the best known sorts of hardy American varieties.

\section{RED VARIETIES}

Brighton. A cross between the Concord and the Diana Hamburg. Bunch large and beautifully formed; berries above medium to large size; usually of a red or Catawba color when first ripe, changing to reddish purple if allowed to hang long on the vine, corered with a blue bloom; skin thin; flesh tender, rery sweet and of fine and excellent flaror; quality best as compared with the finest natire Grapes. The fruit keeps well for an early Grape, eitlier on or off the vines; vine productive and vigorous.

Catawba. So well and farorably known as to need but little notice here. One of our best Grapes, sncceeding well in the ralley and Piedmont regions of Virginia; bunch and berry large, dark red when ripe; flesh very juicy and rich; productire and ralnable in September.

Delaware. This Grape is so well known as to need no commendation. Its earliness, hardiness and admirable sweetness have become too well known to the public to demand more said in its behalf. Bunches medium size, compact; berries rather small; skin of a beautiful light red color; it is without hardiness or acidity in its pulp; exceedingly sweet, sprightly, vinous and aromatic. Ripens in August.

Isabella. An old, well-known sort; large size; dark purple; sweet and rich, with a slightly musky aroma. Beginning of September.

Lutie. This remarkable Grape has never been known to rot. It seenis to be absolutely free from the shortcomings of so many of the leading kinds. It has been tested for ten years, and has fully sustained its reputation. The fruit is of dark red or purplish color; bunch and berry large, exceedingly sweet, sprightly, vinous and aromatic. The rine is a strong grower and regular bearer. Ripens close after Moore's Early.

Salem (Rogers' No. 22). Bunch and berry large; of a light chestnut color: skin thin; flesh tender, very sweet and sprightly, with a rich, aromatic flaror; rine rigorous and productive; ripens before Concord. One of the best and most popular of Rogers' Hybrids.

Vergennes. A chance seedling from Vermont. Skin light red, rather thick: flesh tender, juicy, well-flavored; very good quality. Ripens with Concord.

Wyoming Red. Ripens with Delaware; somewhat similar, though larger in bunch and berry; light red; early; rine strong grower and hardy.

\section{BLACK VARIETIES}

Concord. There is no Grape in this Catalogue so popular or planted so extensively as this. It succeds well in almost all parts of the country, and. although of northern origin, is better here than in its native place. It receired the $\$ 100$ premium offered for the Grape of the greatest value. Vine a rery vigorous grower and enormously productive, comparatively free from disease; bunches large, compact; berries large, round, black, with a blue bloom; a profitable market sort.

Campbell's Early. The King of American Grapes. Another season's experience confirms and strengthens the entire confidence heretofore expressed that the introduction of this Grape marks an epoch in the substantial advancement of American Grape culture, not less distinct and important thar that which followed the appearance of the Delaware (introduced by Mr. Campbell) or Concord. It has been rery carefully observed

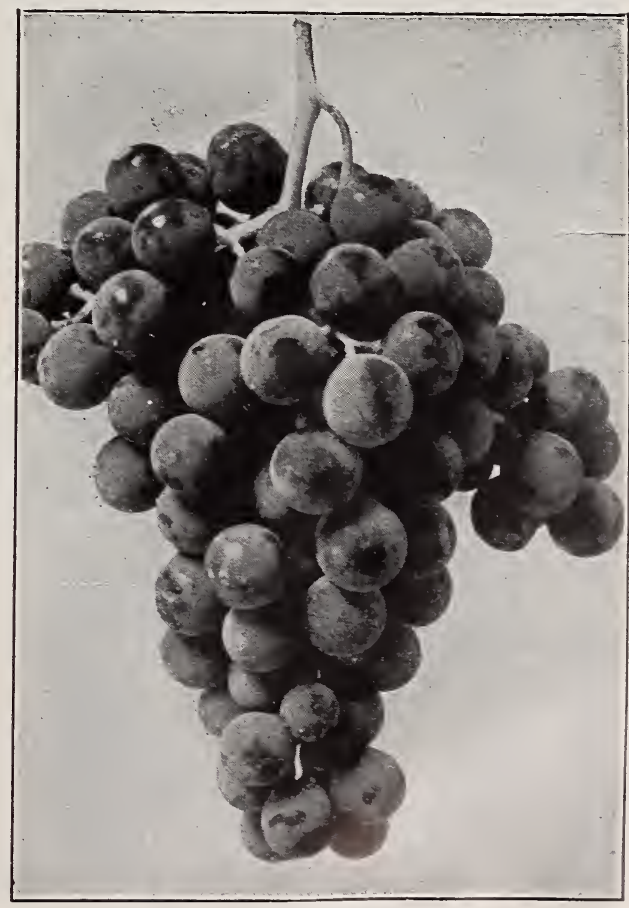

BRIGHTON GRAPE 
BLACK GRAPES, continued and tested more than a dozen years, during which time it has shown no fault, but has exceeded all expectations as to its evident merit and high charactor. It is confidently beliered to be a Grape in all respects better adapted to general use in all sections suited to our native varieties than any other which has yet been grown and tested. A very strong, vigorous, hardy vine, with thick, healthy, mildew-resisting foliage, and perfect, self fertilizing blossoms, always seting its fruit well and bearing abundantly.

Clinton. A black Grape of medium size, entirely healthy and hardy; a strong, rank grower, requiring thin soil and plenty of room; on strong, rich soil should be allowed to run, and pruned long; often succeeds where most other kinds fail; colors early, but should hang long on the vine. A good table Grape when fully ripe.

Early Ohio. Claimed to be the earliest black Grape known; ten days earlier than Moore's Early. Bunch large, compact and shouldered; berry medium, covered with bloom; hardy as the Concord; strong grower and very productive; quality good; first-class for market.

Eaton. Origin, Massachusetts. A seedling of the Concord; stronger grower; large, black; the bunch and berry strongly resembles Moore's Early, the skin rather thick and covered with heavy bloom; juicy, with some pulp, though tender; has less native odor than the Concord; large and attractive. Early.

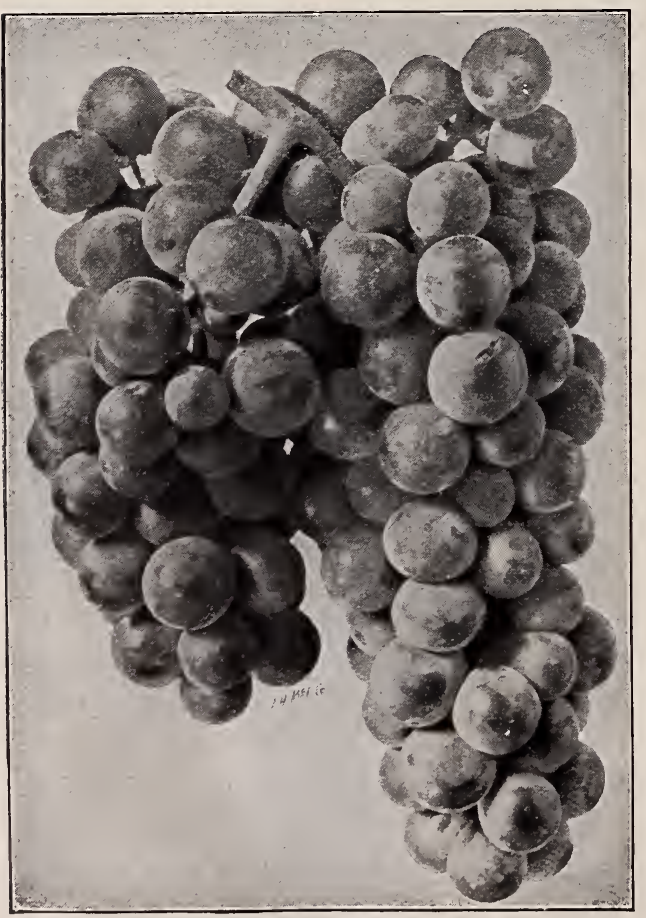

CAMPBELL'S EARLY GRAPE
Ives. Bunch mediun to large, sometimes shouldered, compact; berries medium black; flesh sweet, pulpy and somewhat foxy; should hang some time on the vine after it colors; hardy, rigorous and bears well; deservedly becoming popular. Early.

McPike. (New.) Said to be a seedling of Worden, which it resembles in color, quality and time of ripening. Bunch large, berries very large.

Moore's Early. A seedling of the Concord, combining the vigor, health and productiveness of its parent, and ripening a few days earlier than the Hartford; bunch medium; berry quite large; color black, with a heavy blue bloom. Its extreme hardiness and size will render it a popular market sort.

Norton's Virginia. Bunch large, shouldered; berries small, round; skin thin, dark purple, nearly black; flesh purple, with a brisk, rather rough flavor; vine vigorous, productive and free from disease. Last of - August.

Worden. Said to be a seedling of the Concord, and is a slight improvement on that variety; ripens a few days earlier; bunch large and compact; berry large, black and of good quality; vine vigorous and productive. Will become very popular for the vineyard and garden.

\section{WHITE VARIETIES}

Empire State. Another new white Grape of great promise; bunch large-shouldered, berry medium, skin slightly tinged with yellow; flesh tender, rich, juicy, sweet and sprightly; ripens a little after Hartford; vine a good grower and productive.

Goethe (Rogers' No. 1). Bush and berry large; skin thin, yellowish green, tinged with red; Hesh tender, melting, sweet and delicious; strong grower and very productive; deservedly becoming popular. First of Sept.

Green Mountain, or Winchell. Well tested; the berry is medium size; color greenish white, with delicate white bloom; flesh juicy and sweet; remarkably free from mildew, and will do well in any soil where the Concord grows. A valuable early variety.

Martha. This is one of the most reliable white Grapes yet known. Bunch medium, compact, shouldered; berry white or greenish, turning to pale yellow when fully ripe; skin thin; flesh very sweet and juicy; a seedling of the Concord, and will take the same rank amollgst white Grapes that its parent does amongst the black. Ripens a little earlier than Concord.

Moore's Diamond. Origin, New York. Said to be a cross between Concord and Iona. This handsome new white Grape has met with general favor; its extreme early ripening alone would make it valuable, coming in two or three weeks ahead of Concord; the bunch is medium size, slightly shouldered; color greenish white, with a yellow tinge whell fully ripe; flesh juicy and almost without pulp; few seeds. 
WHITE GRAPES, continued

Niagara. No Grape has been so strongly presented for public faror as this, and for a while it seemed as though it would merit all the praise bestowed upon it. The rine is remarkably rigorous and productive; buuch large, generally shouldered ; berry large, roundish; color greenish white, turning to light rellow; skin thin, but tough; Hesh slightly pulpy, tender and sweet; has a decided foxy flavor before fully ripe, which it pretty well loses at maturity. Ripens with Concord. In some rinesards it has suffered greatly from rot, but where it succeeds it is unquestionably a rerr raluable sort.

Pocklington. A seedling of the Concord. Vine very hardy, healthy and productive; bunch large, generally slouldered; berry light golden yellow when fully ripe; quality good : ripens rather early. It is a good keeper, and bears shipping well. It will probably take its place as a raluable standard Grape, being the largest white Grape of its type yet introduced.

Scuppernong. A southern Grape, too tender for a more northern latitude than Virginia, but southward it is quite hardy and raluable. Vine a vigorous grower, requires no pruning; bunch small, loose, not often containing more than six berries: fruit large, round; skin thick, light green; flesh pulpy, juicy, sweet; produces enormous crops; continues in season about six reeks.

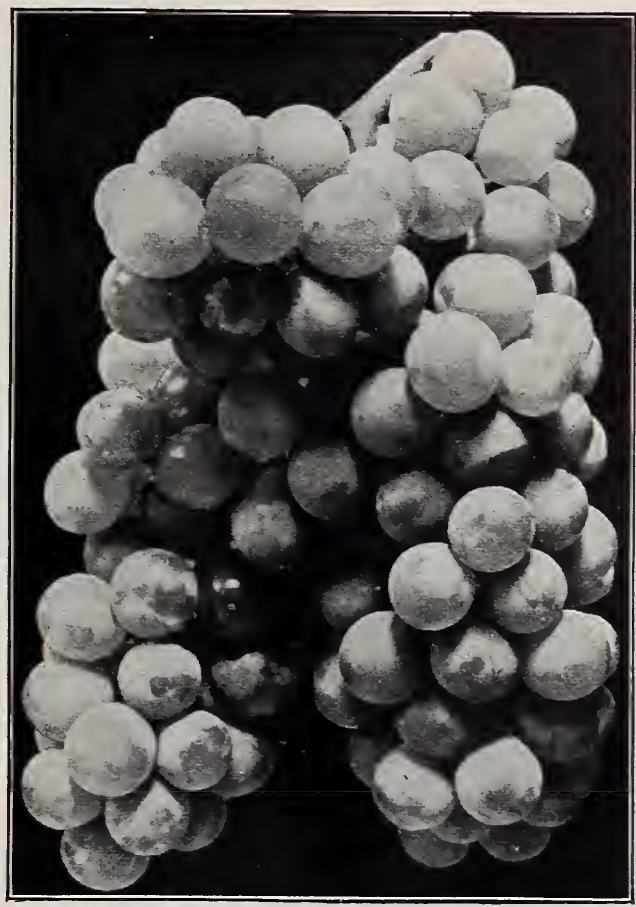

MOORE'S DIAMOND GRAPES

\section{GOOSEBERRIES}

There has been a great demand for these plants for sereral rears on account of the profitableness of the crop, the demand having exceeled the supply. Prices in the Baltimore markets have been from 6 to 10 cents per pound, wholesale.

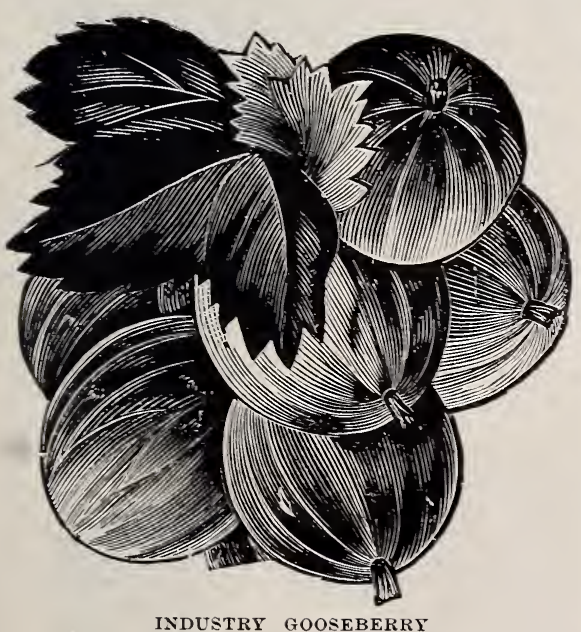

Downing. A seedling of the Houghton. An upright, vigorous-growing plant; fruit larger than its parent; color whitish green; flesh rather soft, juicr, rerv good: productive ; valnable market sort.

Houghton's Seedling. Rather small; pale red; Hesh tender, juicy, sweet and pleasant; produces enormous crops; free from mildew; most profitable market variety.

Industry. English origin: the best for eign Gooseberry ret introduced: ver large, dark red, excellent quality, beautiful, and an enormous bearer.

Pearl. Said to be the most prolitic Gooseberry ret known. Originatei by Professor William Saunders, of the Experimental Station at Ottawa, Canada. It has also been thoroughly tested at nearly all of the experimental stations in the Lnited States for the past four sears. ant l reports are unanimous in its faror. It is a wonderful cropper, strong grower, and free from mildew. Fruit one-third larger than Downing.

Red Jacket. Plant rigorous and healthy. Fruit rich dark red: oblong. Beliered to be valuable.

Smith's Seedling. A new rarietr grown from seed of the Houghton; more rigorous and upright in growth of plant than its parent; the fruit is larger and somewhat oral in form; light green; flesh moderately firm, sweet and good. 


\section{CURRANTS}

Currants should be planted on good soil, which must be kept rich and well worked. Trinl out the old wood as soon as it begins to decline, and shorten all the young shoots, to keep the bushes in good shape. Sprinkle ashes around the roots occasionally to keep the borers away. The currant-worm may be destroyed by sprinkling the bushes with powdered white hellebore while they are wet with dew. This powder is poisonous, and, where it has been applied, the fruit should not be used without first being washed.

The Currant comes partly with the Raspberry, but follows it several weeks. Indeed, none of the small fruits will remain so long on the bushes without injury as the Currant.

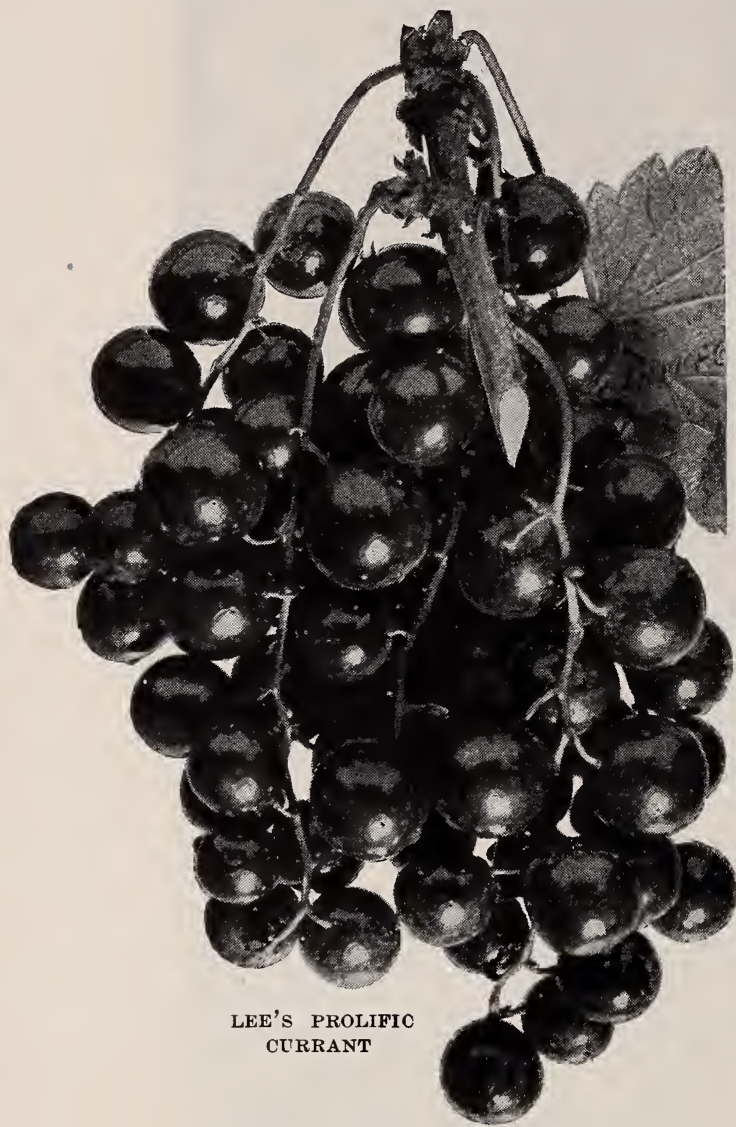

Black Naples. Very large; black; valuable for jams and jellies; has a strong musky odor.

Cherry. Very large; red; strong grower and moderately productive; fine for preserving and a valuable market variety.

Fay's Prolific. This Currant has now been before the public a number of years, and we beliere has pretty well sustained the claims of its disseminator, who says of it: "Color rich red; as compared with the Cherry Currant, Fay's Prolific is equal in size, better in flavor, containing less acid, and fire times as prolific, and from its long, peculiar stem, less expensive to pick."

Lee's Prolific. A black variety of recent introduction, and perhaps the best of its class. Earlier than Black Naples, with the peculiar musky flavor of that variety; fruit large; very prolific.

La Versaillaise. One of the largest and best Currants; an enormous bearer; red; flavor good; very similar to Cherry.

North Star. This new Currant is of remarkably vigorous growth and wonderfully prolific; the stems of fruit thickly set average four inches in length. The fruit is very sweet and rich, a fine dessert fruit and unequaled for jelly. Its large, long clusters can be more rapidly picked than other kinds. It is extremely hardy, easily propagated, bears early.

Red Cross. Jacob Moore, the originator, says: "Red Cross clusters are long and have well-necked berries, double the size of Victoria, and far superior in quality to Cherry or Victoria. Nothing will compare in quality with Red Cross but White Dutch, which is too small. Red Cross was first fruited in 1889. We have seen the fruit growing in such masses as to hide the upper branches from view. It is later than Cherry. The plant makes twice the growth of Cherry, and yields two or three times as much fruit. We recommend it with confidence. We consider Red Cross one of the best of the new Currants."

Red Dutch. Larger than the common red, and clusters much larger and less acid; one of the best red Currants.

White Grape. The best white Currant; bunch moderately long; berries large; very productive, less acid than the red Currants; fine for the table.

\section{RASPBERRIES}

Will do well on any soil that will produce a good corn crop. Land should be thoroughly prepared and well enriched; ground bone is one of the best fertilizers. Keep well cultivated and free from weeds and suckers. As soon as they are done bearing, cut out the old wood to give more vigor to the young canes. Spring is the best time to plant Black Caps. Plant in rows 5 feet apart, 3 feet apart in rows.

Cumberland. Black. Very large. Very similar to Gregg in quality and firmness; in hardiness and productiveness it is unexcelled. One of the best mid-season market varieties.

Columbian. Dull purple, very large, moderately firm. A good market berry and one of the best for canning. Bush remarkably strong and wonderfully productive. 


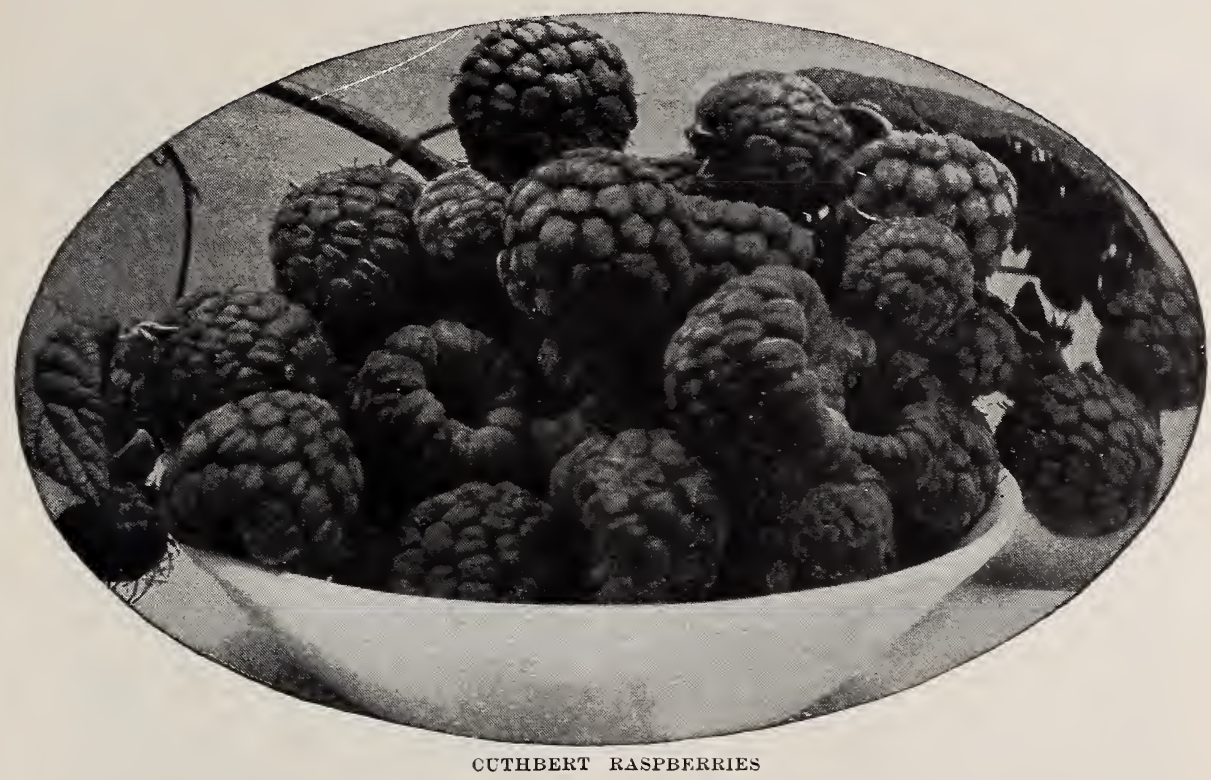

RASPBERRIES, continued

Cuthbert (Queen of the Market). Canes strong, upright, very vigorous, sometimes branching; foliage luxuriant; fruit large to very large: red; moderately firm, with high sprightly flavor; very productive. Its many valuable qualities render it desirable for home or market culture. It succeeds well generally, and is almost the only one that can be relied on in the cotton states. We commend it to planters in all sections.

Gregg. This is one of the largest, if not the largest, of the black cap family; fi uit large, black, with a slight bloom; flesh quite firm, moderately juicy, sweet and rich; the fruit ripens late and very evenly, making the picking season short; it is a very strong grower and good bearer. Very desirable.

Golden Queen. A seedling or "sport" of the Cuthbert, and in hardiness and vigorous growth of plant resembles that variety; fruit of lirge size; color beautiful yellow; flavor excellent.

Kansas. Black. Berries as large as Gregg and of better color; very little bloom; of best quality; ripens early. Very strong grower and immensely productive.

Loudon. Dark crimson, large, firm, of good quality. The best mid-season market variety. Very vigorous, hardy and productive.
Miller Red. This new red Raspberry originated in Sussex county, Delaware, and is rers popular in that section; fruit about the size of the Cuthbert, and holding its size to the end of the season; color bright red, and does not fade; core very small; the finest and best shipping berry in existence; ripens early; heary bearer.

Munger.-Description of introducer. The fruit of Munger is black, and resembles Gregg very much. It is a better flarored berry than Gregg, tougher in texture, and therefore a better shipper. In size it excels Gregg by almost 25 per cent, being extra fine for canning and evaporating. Its season of ripening is from 5 to 8 days later than Gregg, and it has a special faculty of withstanding drought and hot sun. The past season, when most others were dry and seedy, Munger ripened up sweet and juicy, and readily brought an adrance of 50 cents per bushel over other kinds. The canes, too, resemble Gregg, are free from disease, upright in growth, and have never yet been affected by the cold of winter; originated in western Ohio by Timothy Munger, now of California.

Souhegan (Cap). A week or ten days earlier than Doolittle; strong grower; very hardy; fruit large, jet black, handsome; one of the very best of the caps.

\section{WINEBERRY}

Of Japanese origin. A norelty that has created quite a sensation in the horticultural world, and proved itself to be a valuable acquisition. The plant is quite distinct; it belongs to the raspberry family, and is large, robust and perfectly hardy. The berries are half transparent and beautiful, ranging in color from an amber to crimson as they ripen; in general appearance they resemble the raspberry: the quality is distinct, rich, sprightly, with a sharp subacid; elegant for cooking. canning or jelly, far surpassing the huckleberry, raspberry and many other small fruits. It begins to ripen in July, and continues a long time. It is also a handsome ornamental shrub, and its freedom from insect pests and rust makes it valuable indeed. 
The culture of these is about the same as that of the raspberry, but if the soil is not very rich they may be set 5 by 2 feet in the row; on rich soil $6 \frac{1}{2}$ by 3 feet. It requires about 3,000 plants per acre. They should be topped 2 feet from the ground for laterals; do not let more than 3 canes grow to the hill. The past seasons have proved to us that there is as much profit in Blackberry culture as in any other branch of fruit-growing. The culture of Blackberries is not so general as the profits would justify, the demand being always good in the larger cities.

Eldorado. We are more than ever impressed with the conviction, after fruiting this berry another year, that we have in this variety the best Blackberry ever introduced. Wherever it has had a trial, its merits appear at once, and hence its quick popularity where tested, so much so that we have already had to decline orders in large quantities.

Like many of our best fruits, Eldorado is an accidental seedling, and takes its name from the town close by where it was found in Preble county, Ohio. It has been cultirated twelve years, and under careful test at differ. ent experiment stations for four years, has never winter-killed or failed to produce a full crop of the finest fruit. The vines are very vigorous and hardy, enduring the winters of the far Northwest without injury, and their yield is enormous. The berries are very large, jet black, borne in large clusters, and ripen well together; they are very sweet, melting and pleasing to the taste, have no hard core, and keep for eight or ten days after picking with quality unimpaired.-Introducer.

Erie. One of the very best large new berries; absolutely hardy; coal black; firm and solid; ripens early.

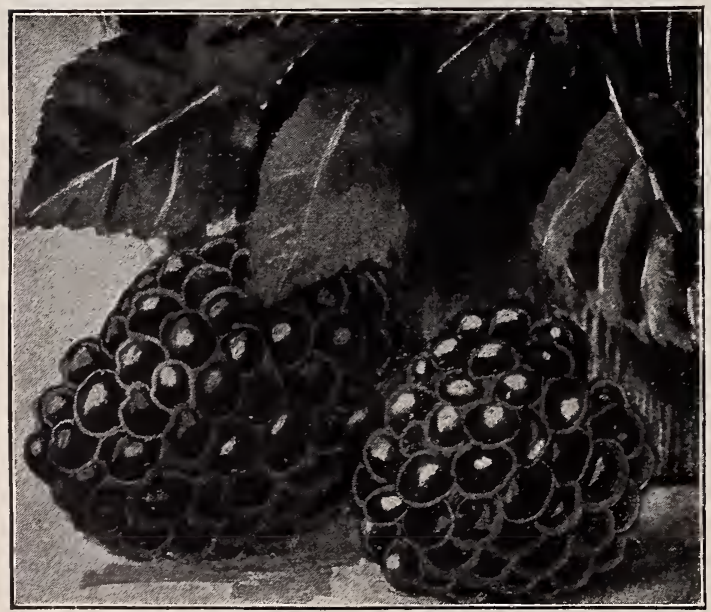

RATHBUN BLACKBERRIES
Early Harvest. One of the earliest, if not the very earliest Blackberry yet introduced, ripening two weeks before Wilson's Early; berry medium size, good quality, and very prolific; it is firm and attractive in appearance; a good market sort.

Iceberg (The White Blackberry). This new novelty is one of Lutber Burbank's productions. Fruit large; early, swet.

Lucretia. This is a trailing Blackberry or dewberry; a good grower and productive; fruit large and of good flavor.

Lawton (New Rochelle). An "old reliable"; large and of best quality; turns black a considerable time before ripening. Late.

Rathbun. A strong, erect grower with strong main stem branching freely; will root from tip of branches like a raspberry. Hardy, having endured 20 degrees below zero and produced a good crop. Forms a neat, compact bush 4 to 5 feet high, producing its immense fruit abundantly. Fruit is sweet and luscious without hard core, of extra high flavor, standing at the head of all for quality; jet black, small seeds; firm enough to ship and handle well. Of enormous size, berries having measured $13 / 4$ inches long by $13 / 8$ inches in diameter, and many of the berries will run $1 \frac{1 / 4}{4}$ to $1 \frac{1}{2}$ inches long; 45 of them have filled a quart basket. Earlier than Eldorado.

Snyder. The hardiest Blackberry known; thoroughly tested in the extreme Northwest, never known to winter-kill; fruit medium size and of good quality.

Wilson's Early. A well-known and most valuable sort; it is of very large size, and very productive, ripening its fruit quite early and maturing the whole crop in a short time, adding thereby greatly to its value as a berry for early marketing. There has been more fruit grown.of this variety during the last twenty years than all other sorts combined.

Wilson, Jr. A seedling of Wilson's Early, said to inherit all the good qualities of its parent, besides being larger and earlier. Probably the best early Blackberry yet introduced.

\section{JUNEBERRY}

This valuable acquisition to the list of "new fruits" has been received with general approval. In appearance and quality it strongly resembles the swamp huckleberry; the fruit is reddish purple in color, changing to bluish black, and is borne in clusters; the flavor is rich subacid; excellent for dessert or canned; tlue plant attains about the same size as the currant; extremely hardy, both to cold and heat; very easy to cultivate; seems to grow and do well with very little care. 


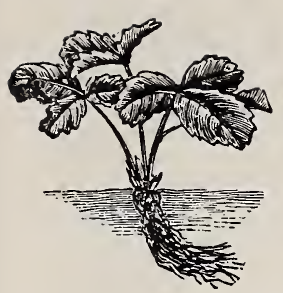

PLANTED WRONG WAY

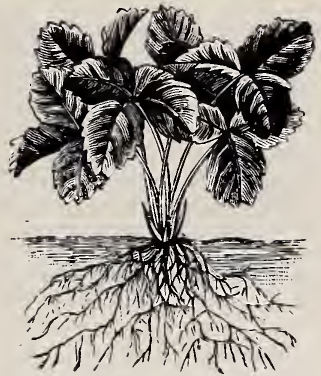

PLANTED RIGHT WAY

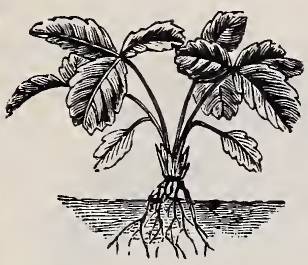

PLANTED TOO SHALLOW

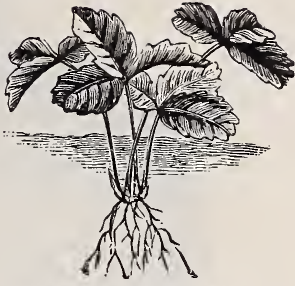

PLANTED TOO DEEP

\section{SELECT STRAWBERRIES}

The Strawberry at present occupies a very prominent place in the catalogue of fruits, and nowhere is there greater reason for a people to be interested in its culture than in the Middle States. It is at home in our soil, and ripens its fruit so early as to give us an opportunity of getting the principal part of our crop into New York and other markets before the more northern grower has a basket of berries to send in. Thus we have the very cream of the market; and that we can send berries to this or even Boston markets by rail or water, and that they can reach their destination in good condition, has been shown to our entire satisfaction.

In garden culture, set the plants in rows 18 inches apart and 12 inches apart in the rows, leaving a narrow walk between every three rows, from which the fruit can be gathered without treading on the bed. In field culture let the rows be 3 feet apart and the plants 12 inches apart in the rows. An acre thus set will require 14,520 plants. The ground shonld be kept free from weeds and grass and the runners cut off as they make their appearance. Thorough preparation of the soil is advised before setting; then shallow cultivation afterwards, so as not to disturb the roots. In the spring the ground should be mulched around the plants, so as to keep the fruit clean. By this course a bed may be kept in good bearing condition for many years.

We have given especial attention to the selection of varieties, both for the amateur and market grower, and believe that our collection embraces the very best sorts. Our plants are of the best quality, and will be furnished at very

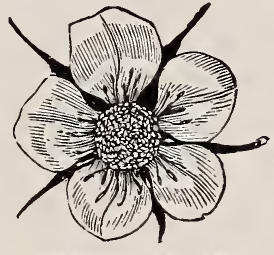

PERFECT FLOWER

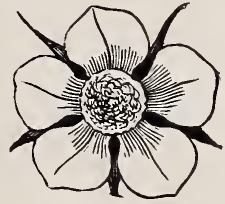

PISTILLATE reasonable rates to those wanting them in large quantities. We will here put in a word of caution against the flaming advertisements of new varieties that are so often heralded before the public. That there is room for improvement, we admit; but the most of these new sorts, so highly puffed, and offered at enormous prices, are destined, like the most of their predecessors, to shine but a short time and then sink into obscurity; perhaps, as the case has often been, to come out at some future day under a new title, to shine again for a short season. It is well enough to try those that seem to merit it, but touch them lightly until they have proved themselves good. Hold on to the standard sorts until something better is found by actual experience.

Those varieties marked $(\mathrm{P})$ have pistillate or imperfect blossoms and must be planted near some variety with perfect blossoms to fruit them.

Bubach No. 5. (P.) This is decidedly, all things considered, the best large Strawberry. Unfortunately it does not stand shipping, but for near-by market and home use it has paid enormously (over $\$ 500$ per acre). It does well on all kinds of soil; being an imperfect flower, it reaches perfection only when fertilized with some good staminate kind as Jessie. Like all Strawberries, it requires a liberal amount of manure; the plant is a strong grower, with only a limited number of runners; dark green foliage, and does not blight or rust; enormously productive; the fruit is large, light red, handsome and delicious. Early.

Clyde. "But few varieties ever introduced have given better satisfaction in all parts of the country. I have fruited it four times and

consider it to be the very best second-early variety ever offered to the American people. With me Clyde is as large as Bubach, nearly or quite a week earlier and very much firmer. It is a strong staminate. I do not think any one will ever regret planting Clyde, as it is a sure producer of fine large berries and lots of them. I shipped quite a lot of berries of this variety last year to the Boston market, a distallce of about 500 miles, and some of the highest prices obtained were for this variety, which proves its shipping qualities beyond a doubt, notwithstanding some statements to the contrary."-Allen.

Crystal City. (P.) Medium size, conical; color light crimson; flesh soft; quality good when very ripe; valuable on account of its early ripening. 


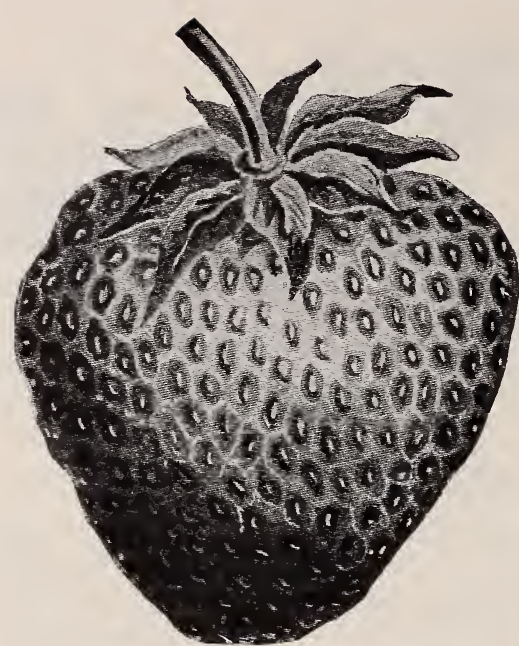

CLYDE STRAWBERRY (Seo page 41)

STRAWBERRIES, continued

Crescent Seedling. (P.) Fruit medium to large; roundish, conical, bright scarlet. It requires less time and attention than most varieties, and is well calculated for those who cannot and will not give the necessary labor to produce the better kinds. It is a hardy, strong, vigorous grower, and very productive; the plant requires much room to give good results; it ripens early and continues late, holding its size tolerably well; and although not of high flavor, its fair size, good color and moderately firm flesh has given it a near market value. Being a pistillate variety, it should be planted near other varieties.

Crimson Cluster. One of the finest late berries yet introduced. Similar to the Gandy, claimed by some to be better.

Excelsior. Large early market variety and is recommended as a good berry for truckers who want a money-maker.

Glen Mary. " This giant among Straw. berries was first offered to the public by me in the spring of 1896 . I have watched every word that has been written or said concerning this variety. I am now satisfied that, all things considered, it is without an equal, it being large to very large in size, one of the most productive ever grown; of strong, sturdy and healthy growth; highly colored, firm for a large berry, and ranks with the best in flavor."-Allen.

In the summer of 1899 the Glen Mary became famous, having beaten all previous records for size. Mr. Joseph Haywood, who lives near Philadelphia, sent in to the "Farm Journal" office a quart box that was filled to the top with (4) berries of the Glen Mary.

Gandy. A new, very late kind; the fruit is uniformly large, bright red, firm and of first quality; very valuable as a shipper; requires high cultivation to bring it to perfection; is valuable as a fertilizer to use with other kinds, making the latter more faithful; the best late variety.
Haverland. (P.) Origin, Ohio. Seedling of Crescent fertilized with Sharpless; one of the heaviest bearers, though a pistillate; the plants are strong and healthy. It does best on light, fertile soils, making too heary foliage on clay; the fruit is large, long, conical, even in form; light color; very desirable.

Hoffman. 'This new berry has made lots of money for the southern fruit-grower; it does its best south of Maryland; the fruit is medium size, very firm and of good quality; the plant is a strong grower and very productive.

Jessie: A large, handsome, dark red berry; in some localities one of the best market sorts. Strongly staminate; a fine fertilizer for such varieties as Bubach. Vigorous, healthy plant. Midseason.

Johnson's Early. "I must give our customers a word of warning concerning this berry, that is, do not let it get too thick. If properly grown in thin, matted rows, it is going to give satisfaction, as it is one of the finest of the early berries that I know of. Being very showy and attractive in the baskets when picked, a good average medium size, neither very large nor small, it cannot fail to please all who are interested in a good early berry. If allowed to make all the plants it will, the ground will become packed so full that it would be impossible for it to mature a satisfactory crop, and persons who disregard this advice should not complain if it does not meet their expectation, for, if grown as above directed, I still recommend it, and believe it will be a very valuable acquisition. In fact, it is decidedly the best berry of its season, which is three or four days later than Excelsior, and the same as Michel and Hoffman."-Allen.

Kentucky. A native of Kentucky; very large; bright scarlet; sweet and delicious; ripens about a week later than most varieties; fruit firm; a fine market sort; plant hardy and very productive; valuable for the late market.

Lady Thompson. Mr. J. S. Westbrook, one of the largest strawberry growers in N. C., says: "I have shipped the Lady Thompson another season, and my experience has not only confirmed but increased my good opinion of its merits. It has proven its

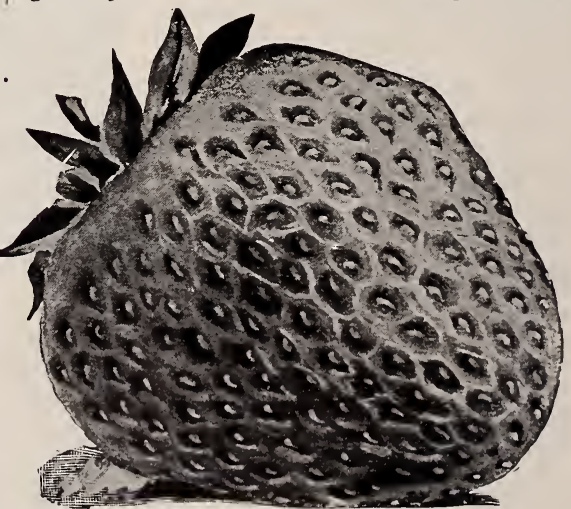

GLEN MARY STRAWBERRY 
STRAWBERRIES, continued

adaptability to adverse as well as farorable surroundings. We have had an unusually dry season, and, while the other varieties of berries succumbed to the drought and many plants died, the Lady Thompson held up and yielded a full crop of large, fine berries. I began shipping them April 6, and at this writing, May 18, there are many berries on the plants, in every stage from the bloom to well-matured, ripe ones, and I am still shipping at remunerative prices, although the market is broken and small berries are worthless. I consider the Lady Thompson invaluable and very far superior to any berry I have ever seen."

Michel's Early. Origin, Arkansas. Six to ten days earlier than Crescent; a perfect flower, and a good fertilizer for other sorts; the berry is large and firm, and of the finest flavor. One of the very best for early market; especially adapted to the South; the plant is a strong, hardy grower, free from rust or blight.

Nick Ohmer. A great surprise is in store for all who fruit this Strawberry for the first time; its mammoth size, beautiful color and great productireness being really astonishing. The plant is exceedingly vigorous, with clean, healthy foliage without the slightest tendency to rust. The berries are of the largest size-a perfect giant among Strawberries-roundish conical in form, uniform and regular; rich, glossy crimson, firm and solid, excellent in quality, and average large to rery last picking. Growers should give this a trial.

Sharpless. This large, showy Strawberry originated with J. K. Sharpless, Catawissa, $\mathrm{Pa}$. Fruit large to very large; bright scarlet, somewhat glossy; flesh light red, quite firm, moderately juicy, sweet, rich and of very good flavor; medium to late in ripening. A

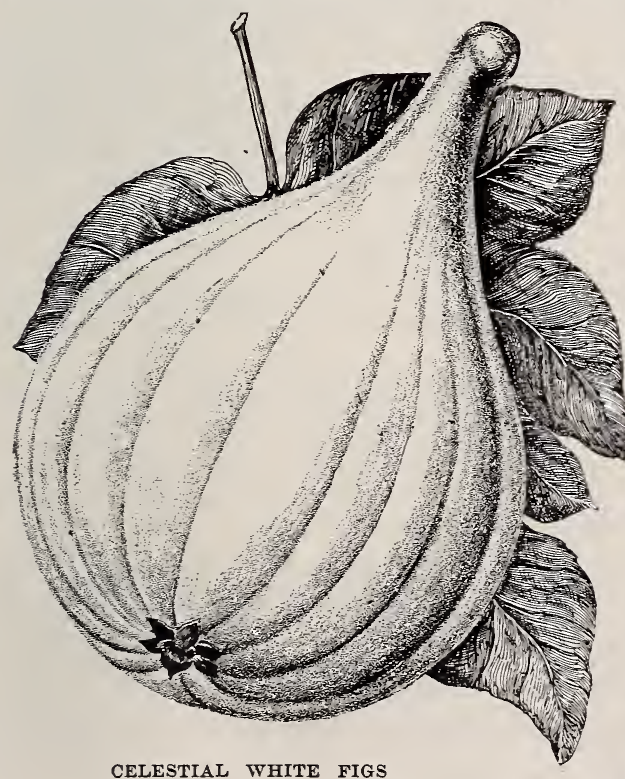

most excellent sort for family use, and also a very profitable one for market. No variety amongst the many new ones introduced during the past fifteen years has sustained its good name so well as this.

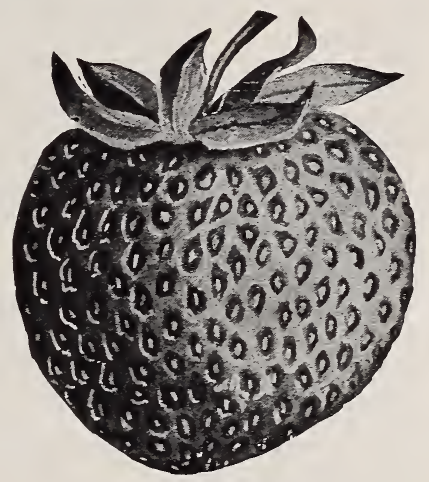

WM. BELT

Tennessee Prolific. Large, good color, productive, of good shape, free from rust and ranks among the best in the Strawberry list. It is a seedling of Sharpless and Crescent, showing the parentage of both. The fruit is a large, handsome plant, and as productive as Haverland.

Tubbs. This is a good berry of Crescent type. In size it runs through the season about like the first picking of Crescent, does not run down toward last part of season like the Crescent. Very productive. In Anne Arundel county, Md., where it originated, it is considered the best berry grown. It has a perfect blossom and is a vigorous grower.

Wm. Belt. Fruit is large, regular, round and conical. It requires high cultivation to make it a success. Color bright red and fine flavor. Medium to late.

\section{FIGS}

This is one of the most desirable of southern fruits, and may be had for table use from June to November. It is well adapted to nearly the whole South, and no home or fruit orchard should be without it. In Virginia and Maryland they are not hardy, and will not stand the winters unless protected. We know of several lots near Baltimore that bear annual crops, but these plants are pinned to the ground and thoroughly covered with earth in the winter, and in the spring this earth is removed. The land for Figs should be well drained and very rich; one of the most desirable places to plant, where only a few trees are required for family use, is near a wash-house or some convenient place where soapy water, ashes, etc., can be placed around the trees. The following are among the best and hardiest varieties: Celestial White, Brunswick, Brown Turkey, Early Violet' White Genoa and White Marseilles. 


\section{ASPARAGUS}

There has been an increasing demand for Asparagus. Coming at a time of the year when the farmer has very little to sell, it has been a very satisfactory and well-paying crop.

Everybody owning a small lot or farm should plant either a bed for home use or a few acres for market. A patch once well established and cared for will last and yield good crops for twenty years.

Directions for Planting. Give land a heavy top-dressing of manure, plow deep, harrow, roll and run rows 4 or 5 feet ipart, about 12 inches deep, then put in 2 or 3 inches of thoroughly rotted manure mixed with bone or bone and potash, then a little good top soil on that and ground is ready for plants, which should be 12 inches apart, being careful to spread roots out well with top up. Cover with 2 or 3 inches of soil. When plants come up, work the earth to them gradually from both sides and from time to time as plants grow, until the ground is level. The middles between the rows should also be worked shallow and grass and weeds kept out. In the fall, after one or two frosts, cut the tops off and burn them, then cover patch with stable manure. Early in the spring, work this manure in the ground, adding, if necessary, some commercial fertilizer on both sides of rows. Salt spread broadcast early in spring, 5 to 10 bushels to an acre, is a benefit.

Barr's Mammoth. Originated near Philadelphia. The largest of all, and, with this great merit, it is very early and quite tender; delicious; light colored; the yield is simply enormous. Decidedly the best Asparagus for all purposes yet introduced.

Columbian Mammoth White. It produces shoots which are white and remain so as long as fit for use. In addition to the marvelous advantage of its white color, the Columbian Mammoth White Asparagus is even more robust and vigorous in habit, and throws larger shoots and fully as many of them as the Conover's Colossal. Marketgardeners, growers for canners, and amateurs should give this great acquisition a thorough trial.

Conover's Colossal. A standard kind of first quality; tender and high-flavored; often ready to cut the second year after planting.

Donald's Elmira. This new Asparagus has attracted much attention throughout New York state, where it was originated by Mr. A. Donald, a prominent market-gardener of Elmira. He has always realized handsome prices and, although a large grower, was unable to supply half the demand. The delicate green color is noticeable, different from either the famous Barr's Philadelphia Mammoth or Palmetto, while the stalks are more tender and succulent. Its mammoth size can

be realized from the fact that in whole crops a bunch of twelve stalks will average four pounds in weight. It requires much less labor in cutting and bunching, thus lessening the expense of marketing.

Giant Argenteuil. This variety was originally a selection from imported French Argenteuil stock, but $h * s$ been both acclimated and improved, and is much superior to the original stock. It has been grown for several years, by some of the leading and most successful truckers, near Charleston, S. C., and is pronounced superior to Palmetto or any other variety in earliness, productiveness and size of stalks produced. One large southern grower speaks of this variety as follows: "I have been growing Asparagus for 30 years, and have grown both Palmetto and Argenteuil, and there is as much difference between them as there is between Conover's Colossal and Palmetto. And for my personal experience of Conover's Colossal and the Palmetto, the Palmetto is twice the size of Conover's Colossal, and longer-lived. And I consider Argenteuil twice the size of Palmetto, earlier, more prolific, and longer lived."

Palmetto, or French. Southern origin; new. Ten days earlier than other kinds; valuable for home or market; largest, tender; very regular growth; one of the best.

\section{RHUBARB, or PIE - PLANT}

This very desirable vegetable comes early in the spring. The large stems of the leaves are used for pie-making and stewing; it is also valuable for medicinal purposes. We grow the best varieties.

A deep, rich soil is indispensable to secure large, heary stalks. Plant in rows 4 feet apart, with the plants 3 feet distant. Set so that the crowns are about an inch below the surface. Top-dress annually in the fall with stable manure and fork under in the spring.

\section{HORSE-RADISH}

No garden should be without its Horse-radish. As a relish for meats it is unsurpassed. The land should be rich, well manured, plowed deeply, harrowed and free from lumps. As it is a great vegetable to spread, plant in a roomy space by itself. Make rows 15 inches apart, set plants 12 inches from each other. Plant shoots about five inches long, making holes for same with a stick, and set them about two inches under the soil. Have the shoots cut squarely across the bottom, but cut slanting at the top, in order that one side may be a little longer than the other.

Keep free from weeds for the first and second seasons, after which the Horse-radish will take care of itself. 


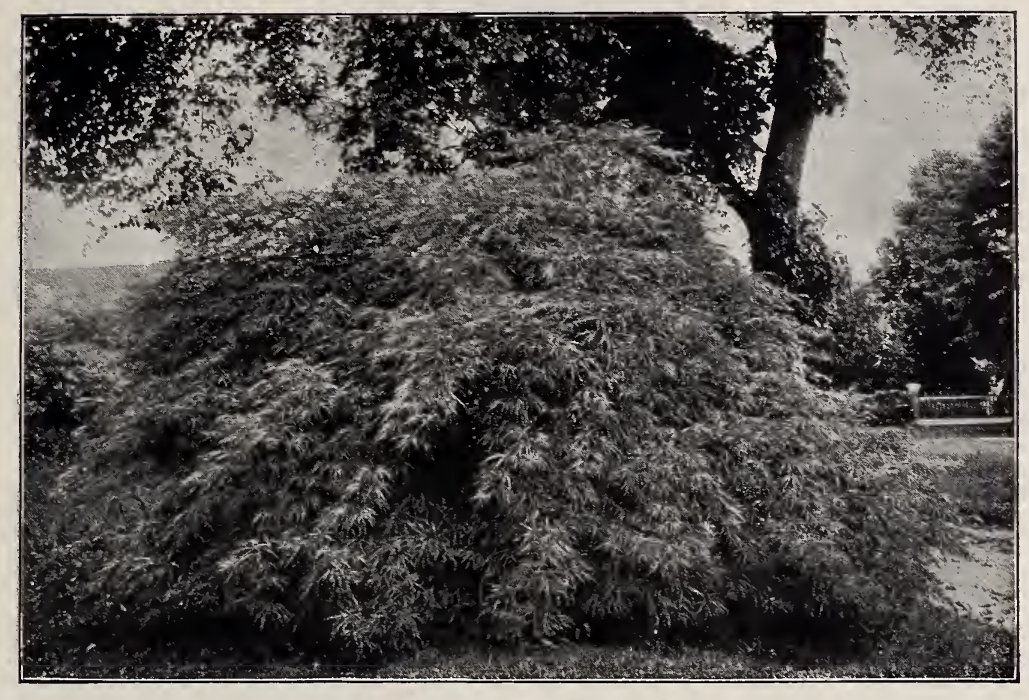

JAPAN MAPLES (See page 48)

\section{Drmamental Bepartment}

In issuing this new edition of our Descriptive Catalogue of Ornamental Trees, Erergreens, Flowering Shrubs, etc., we may say the increasing demand for this class of stock has induced us to make this branch a more prominent feature of our establishment, and to this end we have been steadily working for years, carefully selecting the best and most desirable sorts out of the great mass that has been brought to the notice of the public. That there should be many very good things, and also very poor ones, in these vast collections, is a fact beyond question. For the supply of the amateur, and those whose plantings are to embrace a large collection for variety's sake, it is very proper that they should be supplied; but our purpose is chiefly to furnish material to those who select for true merit, who want trees and plants that will do the most good and give the best satisfaction. It should be kept in mind that, with ornamentals, as with fruit trees, there are some that do well in one place that will fail in another, so that care should be taken, in making up planting lists, to select such only as are known to succeed in the particular locality where they are to be planted. We want trees that will not only show well in the earlier stages of their growth, but those that will maintain a good form and pleasing habit as they grow older; in fact, we should look more to the character of the tree when developed than to its appearance when young. Our stock is in the best possible condition for transplanting, having plenty of room where growing, and in soil eminently suited to the derelopment of a good system of roots. With careful planting, and proper care afterward, there will be but little danger of failure.

\section{Transplanting and Cultivation}

The same adrice concerning transplanting and cultivation, given in our Fruit Catalogue, applies to this department; but, as it is often impossible to cultivate the ground in which shade trees are planted, it will be the more necessary to mulch them well, and not let the grass grow close around the stem of the tree.

Flowering shrubs and evergreens should be carefully planted in good, deep, rich soil, and well mulched. When this is done, watering will seldom be necessary; but when, in case of extreme drought, it may be required, it should be thoroughly done, so as to reach well down to the roots. Very much watering before the leaves expand is a decided injury; let there be just ennugh to keep the earth moist about the roots, not soaking wet, or it may cause them to decay.

The branches should always be shortened back, at the time of planting, in proportion to the loss of roots sustained by the tree in moring.

Those contemplating planting trees should bear in mind that the ralue and beauty of a tree or plant is dependent upon its thriftiness and symmetry rather than its height. 


\section{DECIDUOUS TREES}

Varieties marked with a $\left(^{*}\right)$ are the best for street planting, shading drives and walks.

ASH, European (Fraxinus excelsior). A lofty tree, of rapid growth.

White American ( $\boldsymbol{H}$. Americana). A native tree of large size, pale green foliage; one of the best of the family.

MOUNTAIN ASH, European (Pyms Aucuparia). A small tree, with dense and regular head. In the northern states it is covered from Juiy till winter with great clusters of bright scarlet berries, but here and southward it drops them much earlier, therefore losing much of its beauty.

* American (Sorbus Americana). Tree of coarser growth and foliage than preceding.

Oak-leaved (S.quercifolia). A distinct and desirable tree, with compact, pyramidal head and dark lobed leaves, downy underneath; produces the same flowers and berries as the American or European Mountain Ash. Very hardy, and desirable for planting on lawns or in dooryards. When fully grown, 20 to 25 feet high.

BEECH, American (Fagus ferruginea). One of the grandest trees of our forest; hardy and comparatively free from insect depredations; well deserving of more extensive planting.

Purple-leaved ( $F$. syliatica purpurea). Foliage deep purple in the spring, but under our hot sun and in dry seasons it loses much of its color; for the northern states it is a very desirable tree.

European, or English Beech ( $F$. sy vatica). A beautiful tree, attaining a height of 60 feet or more.

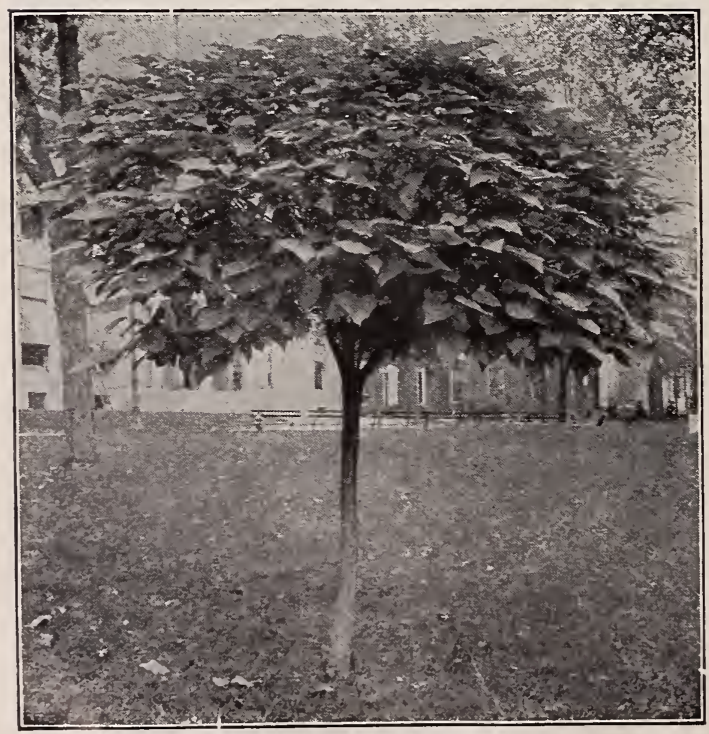

CATALPA BUNGEI
Beech, Copper ( $\boldsymbol{F}$. cuprea). Similar to Rivers' Purple Beech; leaves not so fine a dark purple and turn green much sooner.

Fern-leaved ( $F$. sylvatica heterophylla). A tree of elegant, round habit, and delicately cut fern-like foliage. During the growing season its young shoots are like tendrils, giving a graceful, wary aspect to the tree.

BIRCH, White (Betula alba). A medium-sized tree, quite erect when young, but after a few years the branches assume an elegant, drooping habit, which renders the tree very effective in the landscape.

BOX - ELDER, Ash-leaved Maple (Negundo fraxinifolium). A rapidgrowing native tree, with light green twigs and pinnate leaves; easily cultivated.

CATALPA bignonioides. A native of the southern states; a rapid-growing tree, with large, heart-shaped leaves and large spikes of white and purple flowers.

Bungei. Large, glossy foliage. Grown as a dwarf tree, five feet high and topgrafted; makes a fine umbrella-shaped tree. Suitable for lawn or avenue planting.

Kaempferi. A Japanese species of rapid growth, with cream-colored, fragrant flowers.

speciosa. Originated in the West; said to be finer than the abore, and blooms two or three weeks earlier.

CRABS, Flowering (Pyrus Malus)-

Bechtel's Double - flowering. This Crab is the finest acquisition in the way of a flowering shrub that has been introduced in recent years. It is a rose in disguise, and sweet as a breath of spring. The tree is sturdy, hardy, and free from disease. It grows to be a medium-sized tree and when in bloom presents the appearance of being covered with very delicate pink roses of medium size, scenting the atmosphere for a distance with a perfume surpassing the fragrance of Tea Roses. Small trees have more the appearance of Tree Roses than ansthing else and cut blossoms have often been taken for pink roses. This tree does not blossom until in full leaf, which adds greatly to its beauty.

Sibirica. Red.

Rubra plena. Red-flowering. Alba plena. White-flowering. Floribunda. Dwarf habit. Red berries in the fall.

Spectabilis. White doubleHowering; pink bud; fragrant. 


\section{DECIDUOUS TREES, continued}

Crabs, Toringo. Yellow-fruited; pretty in the fall.

Parkmani. A double-flowering variety from Japan. One of the most beautiful trees for lawn decoration. A compact grower, with persistent dark green foliage. Flower buds long, tapering, of a rich carmine color, on slender stems completely covering the tree.

CHERRY (Cerasus). Large, double-flowering; produces a profusion of double white flowers in the early spring.

CORNUS florida (White-flowering Dogwood). An Americall species of fine form, growing from 16 to 25 feet high. The flowers produced in spring, before the leaves appear, are from three to three and a half inches in diameter, white, and very showy. They begin to appear just as the Magnolia flowers are fading, and are invaluable for maintaining a succession of bloom in the garden border.

Florida flore rubro (Red-flowering Dogwood). A variety of the well-known White Dogwood, but having a deep rosy pink colored flower. The leaves, also, have a soft, velvety appearance, and are of a darker green than the old variety. It makes a good, upright, bushy growth.

CYPRESS (Taxodium distichum). Deciduous Cypress of the South.

*ELM (Ulmus campestris). A native of Europe; a noble, rapid-growing tree, forming a dense head; desirable tree for streets, avenues, etc.

English Cork-barked ( $U$. suberosa). Strong, upright grower; young branches very corky; leaves rough on both sides.

*American, or White (U. Americana). A native tree of large size, with spreading head and graceful, drooping branches. Of all trees, no other perhaps, unites in the same degree majesty and beauty, grace and grandeur, as this one does. It flourishes in all parts of the country, and deserves to be more generally planted.

FRINGE TREE, White Fringe (Chionanthus Virginica). A small native tree, with ash-like leaves and drooping racemes of pure white flowers, resembling an elegant fringe.

HAWTHORN (Cratregus oxyacantha). The celebrated English hedge plant; not so valuable here for that purpose.

Double White ( $C$. flove pleno). Has small, double white flowers; quite ornamental in flower and foliage.

Double Pink. Rose-colored flowers, and produced in great abundance.

Double Red. Bright, double red flowers

HERCULES' CLUB (A ralia spinosa). A small-sized, singular-looking tree with prickly stems, and bearing immense panicles of white flowers in midsummer. Desirable to plant for screen or on lawn. If allowed to, it will sucker and form a clump.
*HORSE-CHESTNUT, Common White flowering (Ásculus Hippocastanum). A handsomely-formed tree, with very attractive flowers; succeeds well in the northern states and in the elevated portions of the southern states; but in many places South its foliage burns.

Red-flowered ( $A$. vubicunda). A superb tree in both foliage and flower; the foliage is darker green than the white, and the flowers showy red, coming later.

Ohio Buckeye ( $A$. glabra). A native of the western states, forming a largesized tree; flowers pale yellow.

Dwarf (Pavia pariflora). An ornamental flowering bush of spreading habit; flowers in summer.

JUDAS TREE, or Red Bud (Cercis Canadensis). A very ornamental tree of small size, with heart-shaped leaves, and is covered with a profusion of delicate pink flowers before the foliage appears.

Japan Judas Tree (C. Japonicum). Recently introduced from Japan. The flowers are larger than the above species, and of a light rose-color; it is entirely hardy and very beautiful.

KENTUCKY COFFEE (Gymnocladus Canadensis). A large-growing tree, with rough bark, stiff blunt sloots, and feathery foliage.

KOELREUTERIA (Kolreuteria paniculata). A small tree, valuable because of its yellow flowers and pretty foliage.

LARCH, European (Larix Europceus). A beautiful, rapid-growing pyramidal tree, with all the characteristics of an evergreen, except that it drops its foliage in the autumn; very desirable.

LABURNUM, Golden Chain (Cytisus Laburnum). A very ornamental small tree, a native of Europe, with smooth, shining foliage, bearing a profusion of drooping racemes of yellow flowers.

*LINDEN, American Basswood (Tilia Americana). A large, native, rapidgrowing tree, with large leaves and fragrant flowers; fine for street or lawn planting; is becoming very popular, and deservedly so, as it is a fine tree.

European ( $T$. Europcea). A fine pyramidal tree, more compact in its habit than the above, but does not attain so large a size; a very popular tree.

LOCUST, Yellow (Robinia Pseudacacia). A native tree of large size, of rapid growth, possessing a soft and graceful foliage, with a refreshing tint of light green; flowers white or yellowish, very abundant and fragrant, and growing in long, pendulous racemes.

Rose Acacia, or Moss Locust ( $R$. hispida). A native tree or shrub, of spreading, irregular growth, producing long clusters of rose-colored flowers.

M A I E N H A I T RE E, or Japan Ginkgo (Salisburia adiautifolia). A remarkable tree from Japan, with leaves resembling the Maidenhair Fern. Valuable for lawn and avenue planting. 


\section{DECIDUOUS TREES, continued}

\section{MAPLES $(A c e r)$}

English, or Cork-barked (A. campestre). A slow-growing tree, of compact, roundish habit, with corky bark.

*Norway ( $A$. platanoides). One of the most beautiful and desirable trees known; foliage broad, deep green, shining; its compact habit and stout and rigorous growth render it one of the most valuable trees for street or lawn planting.

* Sugar (A. saccharinum). A well-known native tree, of stately growth, fine form and foliage; very desirable as an ornamental or shade tree.

Sycamore (A.Pseudo-platanus). An European species, of moderate size; leaves large, dark green.

Schwedler's. This beautiful Maple of recent introduction is attracting considerable attention; it is one of the Norma family, and of about the same habit of growth; its handsome purplish crimson leaves in May and June, changing to a bronze as they mature, are much admired.

Red, or Scarlet (A. rubrum). A native species, of moderate size, producing deep red blossoms, and in autumn the foliage changes to a brilliant scarlet.

*Silver-leaved (A. dasycarpum). A hardy, rapid-growing native tree, attaining a large size; valuable for producing a quick shade; fine for street and park planting, for which purpose it is planted more largely than any other tree.

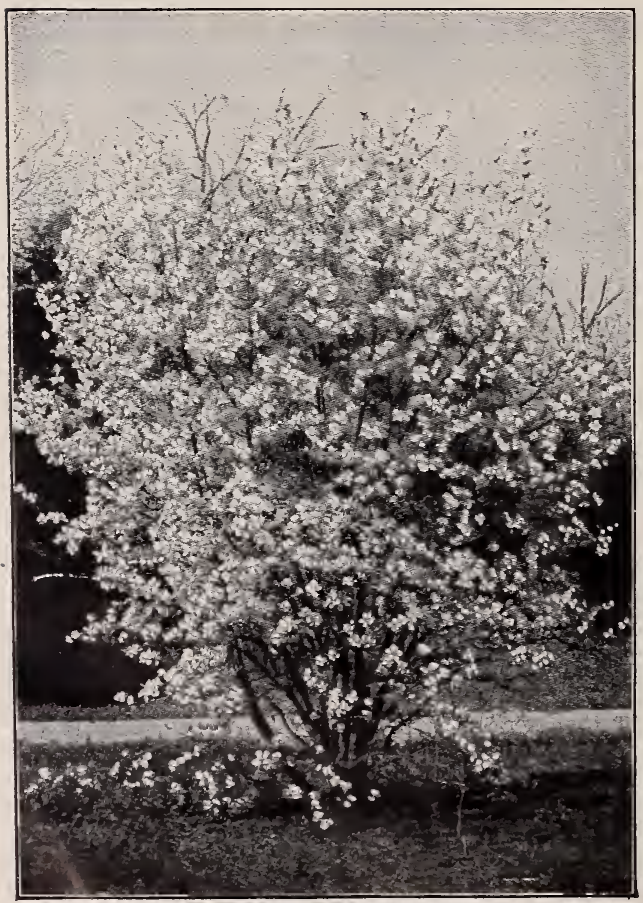

YrT,AN, or $r$ TINESE WHITE MAgNolia (See page 49)
Maple, Wier's Cut-leaved (A. Wieri laciniatum). A silver Maple with remarkable and beautiful dissected foliage. Of rapid growth; shoots slender and drooping, giving it a very graceful appearance; should be in every collection. While it makes a large tree, if undisturbed, it will bear any amount of pruning; easily adapted to small lawns.

\section{JAPAN MAPLES (Acer polymorphum)}

The Japan Maples are becoming more and more popular as they become better known. Their chief recommendation is their dwarf habit and attractive appearance. Some of them have foliage of medium size and of rich, bright hues, while that of others is deeply cut and of peculiar form. All are noted either for their singularity or beauty. Planted singly, they are effective, but when planted in groups, embracing varieties possessing various desirable characteristics, they make a beautiful appearance throughout the season. (See illustration, page 45.)

\section{MAGNOLIAS}

Their superior stateliness of form and splendor of growth, the size and richness of their foliage and lavish yield of fragrant flowers all tend to place them in the foremost rank among hardy ornamental trees and shrubs. 'Their proper place is on the lawn, where they show to fine advantage in contrast to the green; or they may be planted effectively on the borders of lawns, with an evergreen in the background to heighten the contrast. Planted in groups, they yield to no rival, and their effect in the early spring is grand beyond description, illuminating the whole landscape and filling the atmosphere with their rich perfunie. Great care should be exercised in their removal, the fibrous roots being preserved as nearly as possible, and carefully guarded from any exposure to wind or sun. While almost any good soil is sufficient to insure their growth, they succeed best in a warm, rich, dry soil.

Alexandrina. Similar to Soulangeana, but blooms earlier.

Cucumber Tree ( $\boldsymbol{H}$. acuminata). A beautiful pyramidal tree, attaining a height of seventy or eighty feet; growth very rapid and upright; flowers greenish yellow.

Everblooming, Chinese Hybrid ( $\boldsymbol{M}$. semperflorens). One of the best yet introduced; rery desirable on account of never being without bloom; purple, large; very pretty.

Grandiflora. See Erergreens, page 52.

Great-leaved ( $\boldsymbol{H}$. macrophylla). A tree of medium size; leaves from 2 3 feet long: flowers 8 to 10 inches in diameter; pure white; very fragrant.

Lenne's (Lenne's Magnolia). A seedling of Purnure; roliage large; nuwers dark purple; very fine. 


\section{DECIDUOUS TREES, continued}

Magnolia, Purple Japan ( $M$. purpurea). A small tree, or rather large shrub; flowers dark purple outside, and shaded to white within.

Soulange's Hybrid Chinese ( $M$. Soulangeana). Shrubby and branchy when young, but becoming a fair-sized tree; flowers white and purple, 3 to 5 inches in diameter; blooms late; handsome and hardy.

Showy-flowered ( $\boldsymbol{M}$. speciosa). Flowers a little smaller than those of Soulangeana, and of ligbter color; blooms a week later, and remains in perfect condition on the tree longer.

Umbrella Tree ( $M$. tripetala). A small-sized tree, of rapid growth, with immense leaves; flowers creamy white, four to six inches in diameter.

Yulan, or Chinese White (M. conspicua). A medium-sized tree, with a regular form; flowers are large and pure white, and appear before the leaves.

\section{OAK (Quercus)}

The Oaks, when they attaiu size, are our most picturesque trees. The species and varieties are numerous, and the majority are adapted to ornament large grounds where they can have an abundance of room. Some kinds, however, are moderate growers and suitable for small places, especially if kept in good shape by a judicious use of the knife. Our collection embraces a variety of forms and includes the finest.

Cup (Q. macrocarpa). One of the most beautiful of Oaks, of massive, open growth, and with large, heavy leaves. The acorns are of the largest size. An interesting feature is the mossy cup which holds the acorn, not to mention its extremely corky bark. It is easily transplanted if pruned severely. 35 to 40 feet.

English (Quercus Robur). Spreading and slow grower, but forms a large, majestic and grand tree at maturity.

Pin (Q. palustris). An Oak distinguished from all others by its peculiar beauty. The leaves are deep green and finely divided. As the tree grows, the branches droop until the lower ones touch the ground. It is also easily transplanted. It is now much appreciated for its great beauty when well developed. The foliage takes on a partly scarlet and yellow color in the fall. As an avenue tree it is unequaled, and it will also thrive as a street tree in cities. 40 to 50 feet.

Pyramidal (Q. fastigiata viridis). This distinct variety grows upright in pyram-

\section{Pyramidal Oak, continued}

idal shape. It is much used by planters. Its dark green leaves remaining without changing color until late fall makes it of much value. A variety of the English Oak. Does well at the seashore. 35 to $40 \mathrm{f} \in \mathrm{et}$.

Red (Q. rubra). A very well-known, rapidgrowing native species. The leaves are large and bright green, and take on a pur.

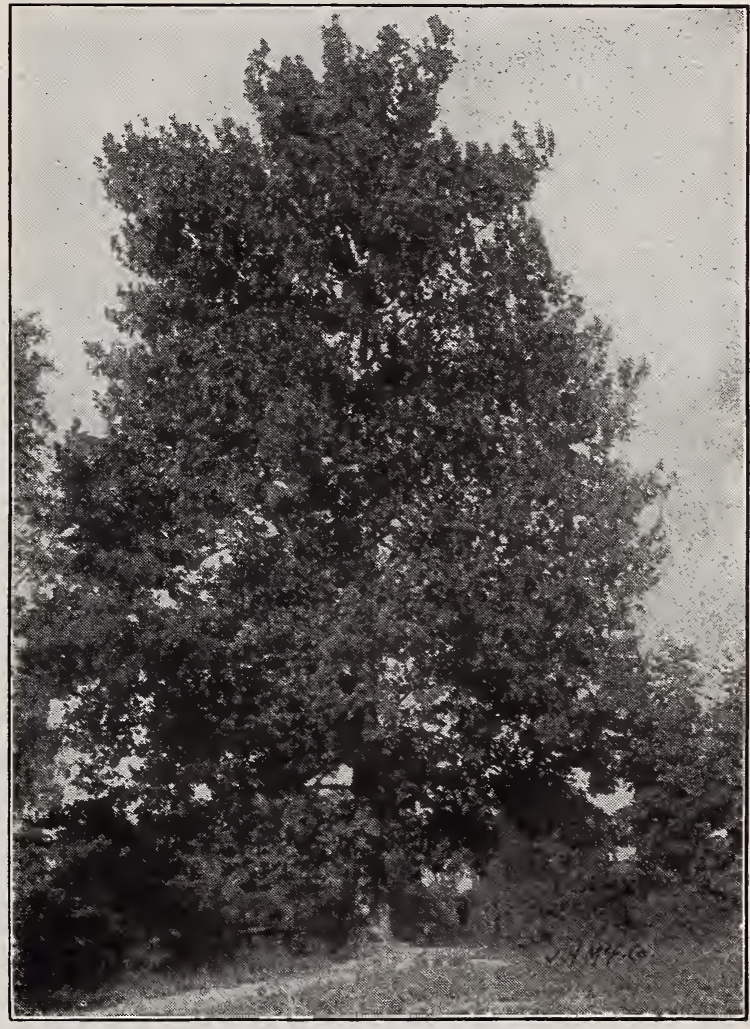

ORIENTAL PLANE (See page 50)

plish scarlet hue in the fall. It becomes of large size. with a round and spreading head. One of the best sorts, not only as a street and avenue tree, but also for ornamental purposes. We especially recommend it. Must be pruned when transplanted. 50 to 60 feet.

Scarlet $(Q$. coccinea). This is perhaps the most esteemed of all Oaks. Not only does it make a large, well-shaped tree, but in the fall the foliage changes to a brilliant scarlet. It makes a fine street or avenue tree, but should be severely pruned when transnlanted. It has very large, shining leaves of a rich green co'or. 50 to 60 feet.

White $(q \cdot a)$. One of the noblest of our native trees, of large size, and widely spreading branches. 


\section{DECIDUOUS TREES, continued}

*ORIENTAL PLANE (Platanus orientalis). A very popular shade tree on account of its shapely and rapid growth, hardiness, and retaining its foliage until late in the season. It makes a fine tree for street planting or lawn.

PAULOWNIA (Paulownia imperialis). A rapid-growing tree with immense leaves; has blue, trumpet-shaped, fragrant flowers.

P E A CH, Double White-flowering (Persica vulgaris alba fiore pleno). Flowers pure white and very double.

Double Red-flowering ( $P$. vulgaris sanguinea flore pleno). Flowers semidouble, bright red, very fine.

Double Rose-flowering ( $P$. vulgaris rosea flove pleno). Flowers double, pale rose-colored; resemble small roses; very pretty. Grouping the three is effective.
Peach, Purple-leaved. A strong-growing Peach with remarkably handsome purple foliage; desirable as an ornamental.

*POPLAR, Carolina, or Cottonwood (P. Caroliniana). A large-sized tree, of remarkably rapid growth, and becoming popular with those who want shade in the shortest possible time.

Golden ( $P$. Canadensis aurea). Golden yellow foliage, retains its tint throughout the season; effective in masses.

Lombardy ( $P$. fastigiata or dilatata). Well known for its erect, rapid growth and commanding spiry form. Very desirable in large grounds or along roads to break the average height and forms of other trees.

TULIP TREE (Liriodendron Tulipifera). A magnificent native tree, with large smooth, shining leaves; flowers tulipshaped, greenish yellow; fine for shade; difficult to transplant except when of small size.

SOPHORA, Japan ( $S$. Japonica). A mediumsized tree, light-colored, soft foliage; flowers of a light cream color, in panicles.

SWEET GUM (Liquidambar styraciflua). A fine native ornamental tree, the foliage resembling that of the Maple; corky bark ; le aves changing to deep crimson in the autumn.

TEXAS UMBRELLA TREE (Melia Azedarach Umbraculiformis). A variety of the China tree; has adense, spreading head, resembling a large umbrella, and is a very desirable shade tree of rapid growth in the South. Not hardy north of Virginia.

WILLOW, Golden ( $S a$ lix vitellina aurantiaca). A handsome tree, particularly conspicuous in winter on account of its yellow bark.

YELLOW-WOOD ( $v i r$ gilia lutea; Cladrastis tinctoria). A fine spreading tree of medium he ight, with smooth, gray bark like the beech, and bright yellow wood. The white Howers, in long, drooping clusters, resemble the yellow locust. It is one of the most graceful of flowering trees. 


\section{WEEPING TREES}

ASH, Weeping (Fraxinus excelsior pendula). A tree of medium size, with stiff, twisted, pendulous branches.

BIRCH, Weeping Cut-leaved (Betula alba pendula laciniata). A charming tree in the northern states, but does not show so much beauty South, except in very favorable locations; it is of very graceful, drooping habit, silvery white bark and delicate, cut foliage. Most effective and pictuiesque.

CHER RY, Dwarf Weeping (Cerasus pumila pendula). A grafted, roundheaded weeping tree.

Japan Weeping (Cerasus Japonica pendula). Has feathery, graceful foliage, white flowers and red fruit.

DOGWOOD (Cornus pendula). Very similar in foliage and Hower to the common white Dogwood, yet with decidedly drooping branches; hardy and very handsome; makes brilliant autumn foliage; a beautiful lawn tree of dwarf habit.

ELM, Camperdown Weeping ( $V 7 m u s$ Camperdown pendula). A drooping and picturesque variety of the Scotch Elm; foliage large, dark green, corering the tree with a luxuriant mass of verdure.
MULBERRY, Teas' Weeping. Fountain-shaped, like the Kilmarnock willow; long, slender branches, drooping to the ground; very hardy and striking; among the best of weeping trees; quite hardy.

MOUNTAIN ASH, Weeping (Sorbus Aucuparia pendula). The branches of this distinct variety are of a straggling, pendent habit; a rapid grower.

WILLOW, Common Weeping ( Satix Babylonica). A mative of Asia. This is one of the most graceful and beautiful of the weeping trees; it is of rapid growth, attaining a very large size, showing its great beauty in damp or moist soils, but grows fairly well in any good soil.

Kilmarnock (S. cuprea pendula). A rariety of the foat Willow, making a rery pretty tree when budded 6 or 8 feet high. It forms a complete umbrella head, the branches and foliage being rery dense; unique in form.

New American Weeping (S. purpurea pendula). A small, slender-branched species from Europe; often known as the Fountain Willow.

Wisconsin Weeping. Of drooping habit and hardier than Babylonica. Valuable on account of its ability to resist serere cold.

\section{EVERGREENS}

Their superior stateliness of form and splendor of growth, their dense foliage and pleasant resinous odor, all tend to place the Erergreens of first importance as ornamentals, especially for the winter landscape. Invalids and many people visit the parts of our country where the Pine or Erergreen forests abound, on account of the atmospheric resinous odors haring a well-founded reputation for healthfulness. The Balsam Fir is especially odorous. A pillow filled with Balsam sprays remains wonderfully fragrant, and gives out much of the regular health-giring properties of a Balsam forest. Such pillows for summer nights are refreshing, to say the least. Those haring extensive yards to accommodate erergreens need not travel great distances to wild forests to secure benefit from erergreen trees.

Early spring planting is the best, though they can be safely mored during wet falls. If soil inclines to be dry in planting erergreens, tramp or pound down the earth quite firmly (but with care) on the roots. Mulching is good for them during dry seasons. We are now giving special attention to the propagation and culture of the perfectly hardy speeies, as follows.

ARBORVITAE, American (Thuja occidentalis). Sometimes called White Cedar; a well-known native species, of great value, forming an upright, conical tree of medium size; especially valuable for screens and hedges.

Chinese (Biota orientalis). From China and Japan; a small tree, with erect branches and dense, flat, light green foliage.

Chinese Golden (B. aurea). This is the most elegant and charming, and justly becoming the most popular of the Arborritæ. The beautiful golden tint of its foliage and the compact and regular outline of its habit render it unusually attractive.

Ever Golden (B. orientalis semperaurea). This very distinct evergreen is desirable on account of its never changing its beautiful bright golden color; very hardy.

Globe-headed ( $T$. globos $a)$. Originated at Philadelphia; forms a dense, round head; dwarfish in habit; desirable.
Arborvitae, Heath-leaved ( $T$. ericoides). A dwarf variety, with heath-like foliage; forms a dense bush but a few feet high. Distinct and ornamental.

Hovey's Golden ( $T$. Hovey $i$ ). Of dwarfish habit; globular in outline; foliage of a light yellowish green hue; hardy and fine.

Lutea. Dwarf, with gold-tipped foliage; rery desirable for small places or cemeteries.

Nootka Sound (Plicata). Similar to Siberian, but with shorter growth, and branches disposed so as to gire them a plaited appearance.

Parsons' (Tsuga compacta). A dwarf of compact habit and yellowish green foliage. Its small size makes it practicable to use in restricted areas.

Siberian ( $T$. Sibirica). A well-known popular variety; tree of medium size, very hardy, of dark green color; compact growth. 


\section{EVERGREENS, continued}

Arborvitae, Tom Thumb. Similar to the Heath-leaved, but more desirable; remarkable for low, compact habit; valuable for planting in cemeteries and small places, where large trees are not admissible.

Upright ( $T$. pyramidalis). Of very erect form; dark green, compact and very desirable.

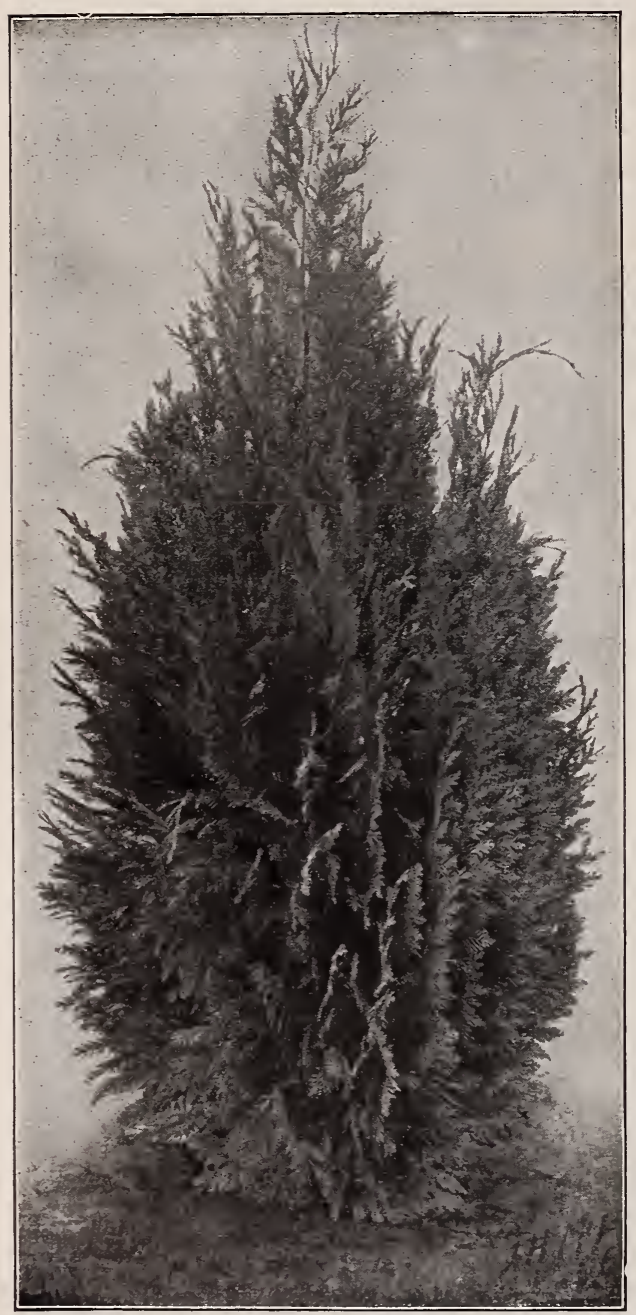

LAWSON'S CYPRESS

BOX, Dwarf (Buxus suffruticosa). The well-known sort used for edging; makes a very pretty little shrub when planted singly.

Common Tree ( $B$. sempervirens). A hand some shrub, with deep green foliage; succeeds well in the shade. lis

no se Iur this
CEDAR, Deodar (Cedrus Deodara). Anative of the Himalayas, being one of the most graceful and elegant of the European trees; growth rapid, branches drooping; foliage light glaucous green; not entirely hardy north of Philadelphia.

CYPRESS, Lawson's (Cupressus Law. soniana). From California; a large, graceful tree, haring elegant, drooping branches; leares dark, glossy green, tinged with a glaucous hue; one of the finest of its class.

Nootka Sound ( $C$. Nutkonsis). A hardy and desirable species from Nootka Sound; pyramidal in habit, forming a tall tree, with dark green, slightiy glaucous foliage.

Lawson's Pyramidal ( $C$. Lawsoniana pyramidalis). Upright and dense in its habit of growth.

Cypress (Imported). We have a fine lot of specimen plants of the following rarieties: Alumnii, Frazeri, Monumentalis, Monu mentalis glauca and Wisselli. These are beautiful plants.

EUONYMUS, Japan. Leares shining green; used for hedging; also desirable on the lawn.

Silver-striped (E. argentea).

Gold Variegated (E. aureus).

FIR, Balsam, Balm of Gilead ( $P$ icea balsamea). A well-known and popular tree; rery pretty when young.

English Silver ( $P$. pectinata). A noble tree, with spreading, horizontal branches; dark, shining green foliage, holding its color well through the winter; it is rather stiff-looking, when young, but makes a splendid tree.

Nordmann's Silver ( $P$. Nordmanniana). A rapid grower, regular in outline; foliage massire, dark green: one of the finest of the Silver Firs.

JUNIPER, Irish (Juniperus Hibernica). $\Lambda$ distinct and beautiful rariety, of very erect, dense, conical outline, resembling a pillar of green.

MAHONIA, Holly-leaved ( $M$. Aquifolium). A native species, with purple, prickly leaves, and showy, bright yellow flowers.

Japonica. This has broader foliage than the other, but it does not change in the winter as the other does. Both do well in shady places as well as in more open ones. 3 to $4 \mathrm{ft}$.

MAGNOLIA grandiflora. The most magnificent of our broad-leaved evergreens. The trees bloom when quite small. The flowers are very large, pure waxy white, and of the most delicious fragrance. All of our plants are nurserygrown, and are finely rooted. 


\section{EVERGREENS, continued}

PINE, Austrian (Pinus Austriaca). A rapid-growing species, with long, stiff, dark green leaves.

Scotch ( $P$. sylvestris). A rapid-growing, hardy tree, with bluish foliage and rugged shoots.

White, or Weymouth ( $P$. Strobus). A well-known native tree; very hardy, and of rapid growth; foliage light silvery green.

Bhotan ( $P$. excelsa). A graceful, elegant tree, resembling the White Pine, but with longer foliage; native of the Himalayas.

RETINOSPORA, Plume-like Retinospora, Japan Cypress ( $R$. plumosa). A very compact-growing variety, with small, light green leaves and short, slender branches; quite hardy.

Obtuse -1 eaved $(R$. obtusa). A pretty and distinct species, growing 6 to 8 feet high, with graceful, drooping branches.

Golden-tipped Plumelike ( $R$, plumosa aurea). $A$ very striking and desirable plant for this cli. mate; the tips of branches showing a beautiful golden yellow hue.

Silver-spotted Plumelike ( $R$. plumosa argentea). Young shoots sprinkled with numerous silvery white dots.

SPRUCE, Douglas' ( Abies Douglasi). A rapidgrowing species, but the foliage browns badly in some localities.

Colorado Blue (A. pungens). A rare, elegant tree with foliage of a rich blue. One of the most distinct and striking of all the Spruce family. A free grower and perfectly hardy.

Hemlock (A. Canadensis). One of the hardiest and most handsome trees, branches drooping; foliage delicate, retaining its color well through the winter; should be in every collection, however small; it also makes a highly ornamental hedge.

Norway (A. exielsa). A European species of very rapid, elegant and lofty. growth, and when it attains to the height of
Norway Spruce, continued

15 or 20 feet the branches assume a graceful, drooping habit. This is one of the handsomest as well as the most popular evergreen trees; a grand decoration for the lawn; very hardy.

White $(A, a l b a)$. A very pretty tree; attains a height of 40 to 50 feet; compact in growth; conical in form, with soft, light green foliage; very hardy; desirable.

YEW, English (Taxus baccata). A small, bushy tree, with rich, dark, glossy green foliage; suitable for clipping into artificial forms.

Irish ( $T$. fastigiata). Of close, erect habit and dark green foliage.

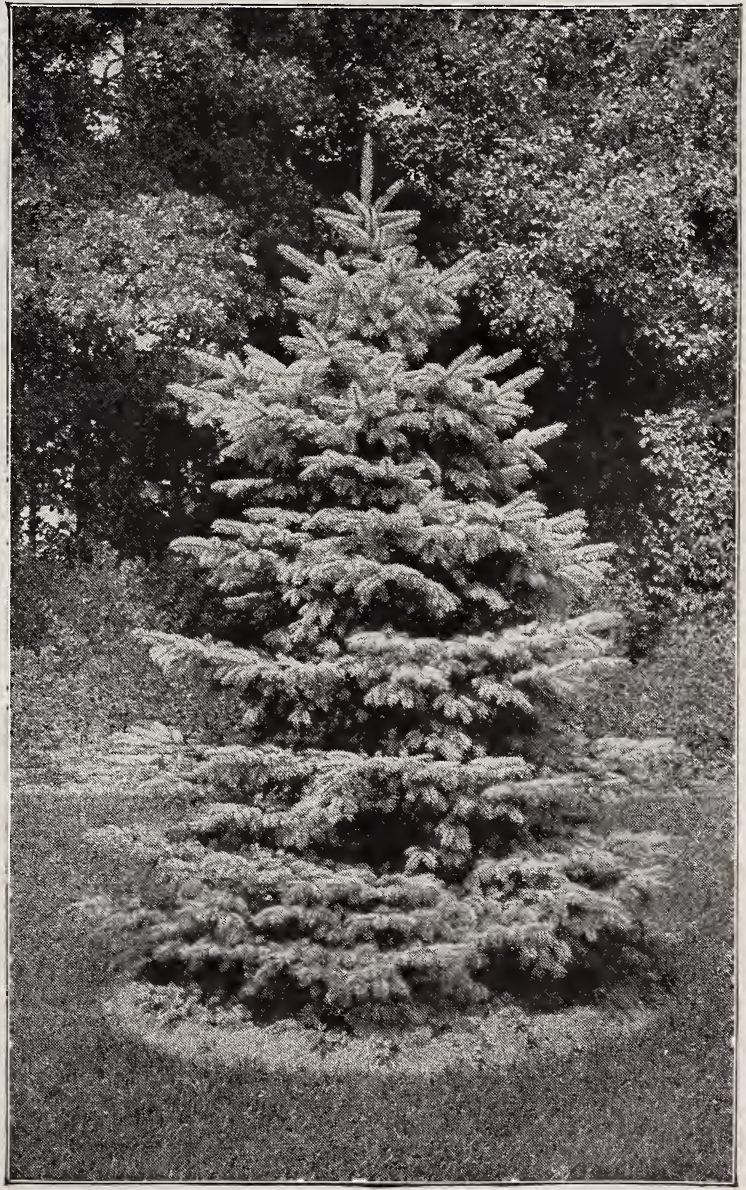

COLORADO BLUE SPRUCE

We exercise the greatest amount of care in the growing of our evergreens, and pay scrupulous attention to the matter of varieties, so that those purchasing evergreens from us can feel assured of getting just what they order. 


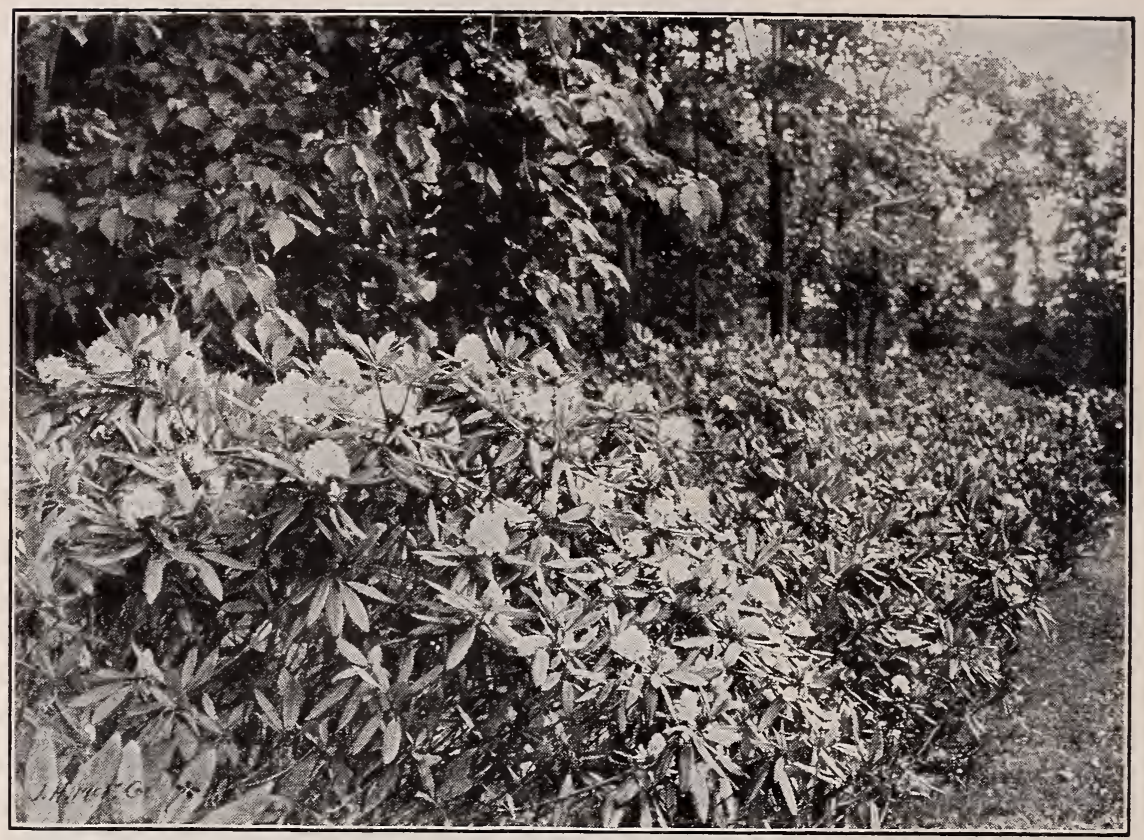

\section{RHODODENDRONS}

Directions for planting beds.-'The Rhododendron is one of the most beautiful plants in cultivation, either when planted as a single specimen on the lawn, or in beds. Its heavy, dark green foliage is striking, both in winter and summer, to say nothing of the great masses of varied colored flowers, which are produced in large trusses on the ends of nearly every branch of the plant. The flowers open during the latter part of April and the early part of May, and, as all the buds do not open at the same time, there is always a profusion of bloom for a period of several weeks. The finest effect is produced by planting in beds; the number of plants in a bed is immaterial, though, naturally, the larger the bed and the more plants there are in it, the greater will be the display. It is a mistaken idea that many have that Rhododendrons are not hardy. Of course, as with many other trees and plants, some varieties will not stand our climate; but we have been handling these plants so long that we are thoroughly conversant with those varieties best suited for this country, and on no account would we sénd anything else but the very best ones.

Rhododendroms have a mass of small, hair-like, fibrous roots; and it has been found that when the soil is light and good drainage given them, they do remarkably well. While they like plenty of water, they are averse to having it stagnant about the roots.

When planting a bed of Rhododendrons, it would be well to see that the following directions are observed in preparing it, so as to produce the very finest effect: The soil should be dug out about four feet deep and the bottom filled in with about two feet of broken stone or similar material, finishing with about two-thirds good top-soil-sod, if it can be procuredand one-third sand, with a good sprinkling of well-rotted stable manure. Prepared in this way, it will be cool and moist all the time. 'The plants can be set about three or four feet apart, according to the size used, and they will thrive, bloom and give a great deal of pleasure. A pretty and desirable effect can be produced by mixing in a few hardy Ghent and Mollis Azaleas along the outer edges of the bed. These do not grow so large as Rhododendrons. and haring different colored flowers, add materially to the beauty of the bed.

While Rhododendrons require no winter protection, we have found it to be time well spent to fill rorest leares, straw, hay or similar material in among them late in the fall. It keeps severe winds from the plants and frost from their roots, and they always look better for it in the spring. An occasional top-dressing of well-rotted stable manure will also be adrantageous. We can furnish the best hardy varieties in assorted colors, with flower-buds.

IF YOU NEFD A GARDENER OR FARMER we should be glad to assist you in finding a F puitable one for your place. Let us know size of place, whether you want single or married man. We keep a number of good men on our lis "nd wou" commend only those we believe to be competent and reliable. We make no. gुo fur this 


\section{FLOWERING AND OTHER SHRUBS}

ALTHAEA, or Rose of Sharon (Hibiscus). The Althæas are fine, hardy, freegrowing flowering shrubs, of easy cultivation, and desirable on account of their late summer-blooming. Our collection comprises a great variety of colors and shades.

Ardens. Bluish purple; a distinct color and good rariety.

Amaranthus. Rich purple; fine.

Anemoneflora. Light red.

Carnea plena. White, tipped with pink.

Duchesse de Brabant. Flowers large; very double, of reddish lilac color. One of the best varieties.

Kanoch, Variegated Leaf. Foliage finely marked with light yellow; produces purple flowers.

Lady Stanley. Large, very double; lovely pure white, with a few purplish stains in throat.

Paeoniflora. Large double pink; pretty.

Rubra plena. Reddish striped; double flowers.

Speciosa rubra. Red.

Totus albus. Pure white; single.

Violacea. Flowers medium size, double; of violet-lilac color; free-flowering; one of the best.

We also have sereral new rarieties not named or described in this list.

ALMOND (Dwarf), Double Rose-flowering $(P r u u u s$ Japonica rosea fl. pl.). A beautiful small shrub, producing an abundance of small, double, rose-like flowers, closely set upon the twig before the leaves appear; very attractive.

White-flowering ( $P$. Japonica alba $f l . p l$ ). Produces beautiful, double white flowers in April.

AZALEAS. These are among the most valued and desirable of shrubs. They are of two classes, the Ghent varieties and the natives. The beautiful, delicately tinted fragrant flowers and waxy green leaves are their distinct characteristics. They are admirable both for grouping and specimen planting.

Amoena. A dwarf erergreen with small leaves and rosecolored flowers; blooms in early spring.

Ghent. Pretty shrubs of the honeysuckle family. Among the numerous varieties may be found nearly every shade of color from white to scarlet; very desirable.

Mollis. A new, hardy, desirable species from Japan; flowers large and showy, in trusses of various colors, resembling the rhododendron.
Azalea Pontica. Fine yellow flowers ; free-blooming; should have some protection in winter.

BACCHARIS halimifolia (Groundsel, or Salt Bush). A rery attractive shrub with whitish flowers, followed by fluffy seed-pods in the fall.

BARBERRY (Berberis). A showy, upright-growing shrub; covered in autumn with brilliant red fruit.

Purpurea. A fine variety, with purple leaves and showy flowers.

Thunbergii. A beautiful Japan variety of dwarf habit. Small foliage, changing to beautiful red in autumn. Very desirable for grouping.

BLADDER SENNA (Colutea arborescens). A large shrub, with small, delicate foliage and pea-shaped blossoms, followed by curious, inflated pods.

BLEEDING HEART (Dicentra spectabilis). A rery hardy and beautiful plant with pretty, heart-shaped, pink flowers.

CALLICARPA purpurea. A valuable shrub from China. Has long drooping branches, covered with violet-colored berries in the autumn.

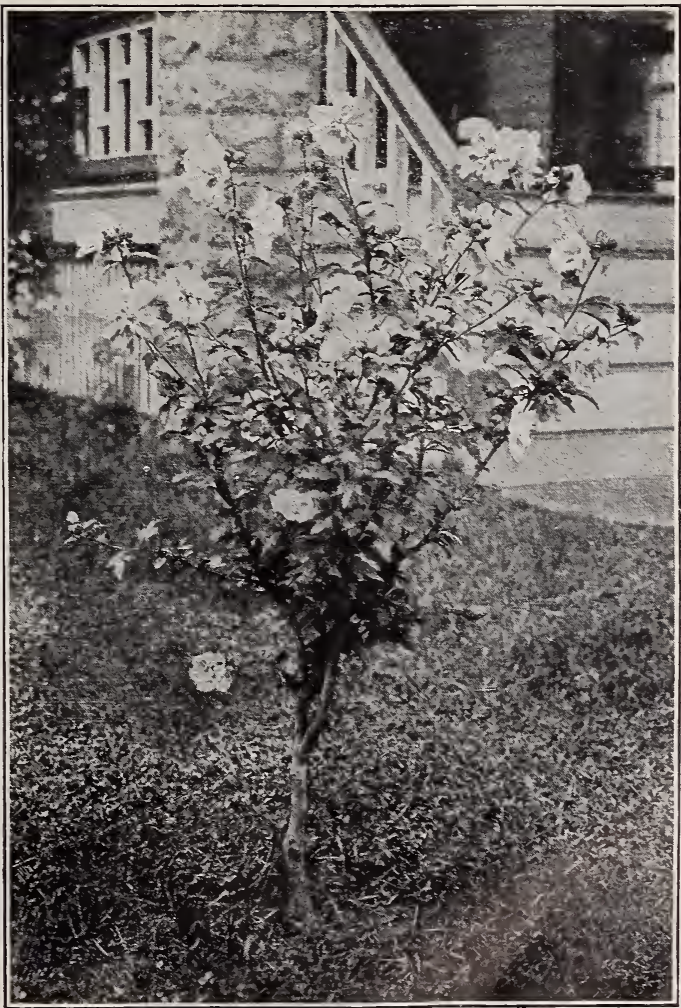

ALTHAA, OR ROSE OF SHARON 


\section{FLOWERING AND OTHER SHRUBS, continued}

CALYCANTHUS floridus (Sweet-scented Shrub). A well-known native bush, the young wood of which has a strong aromatic odor; foliage luxuriant, and the rare, chocolate-colored blossoms are delightfully fragrant; blossoms in May and at intervals during the summer.

CRAPE MYRTLE (Lagerstrœmia Indica). Too much cannot be said in favor of the delicately flowered Lagerstrœmia; universal favorites in the South, and deservedly so. Deciduous shrubs, hardy in the southern states, and producing throughout the summer great clusters of delicately-fringed flowers. In the South the Crape Myrtle takes the place of the lilac, so common at the North. Makes the most charming flowering hedge known. A success with every one.

Purple. A grand sort, producing immense quantities of bloom of a rich purple color.

Scarlet. A very dark shaded variety; in our opinion the best of all. A gorgeous plant.

White. This is quite scarce, and very lovely. A most desirable sort.

CORNUS alba (Stolonifera). Red-twigged Dogwood. This bears bunches of white flowers in early June. In winter the young shoots become of deep blood-red color, for which it is much valued. It should be cut to the ground every spring and allowed to make entirely new growth each summer, to secure the best color to the wood. 4 to 5 feet.

Golden (Spcethii). One of the finest of recently introduced shrubs. The leaves are margined with yellow.

Mascula. Cornelian Cherry. One of the earliest of spring-blooming shrubs, bearing a profusion of small, yellow flowers along its naked branches in the early days of April. They are followed by bright red berries, about the size of a small cherry, which are very ornamental. 8 to 10 feet.
CLETHRA ainifolia. Dwarf and dense in growth; leaves light green. Numerous spikes of white, fragrant flowers are borne in midsummer. Very desirable.

CURRANT, Crimson-flowering (Ribes sanguineum). Small, deep red flowers, blooming very abundantly in early spring.

Yellow-flowering $(R$. aureum). Bright, shining leaves and yellow flowers.

DEUTZIA. We are indebted to Japan for this valuable genus of plants. Their hardihood, fine habit, luxuriant foliage and profusion of attractive flowers render them the most beautiful and deservedly the most popular of flowering shrubs at the present time. The flowers are produced the latter part of June in racemes 4 to 6 inches long.

Candidissima. Of recent introduction. Flowers pure white, large; very desirable.

Rough-leaved (D. scabra). An upright, thrifty shrub, bearing a profusion of white flowers in May.

Slender-branched ( $D$. gracilis). A smaller variety than the preceding; branches slender and graceful, producing a profusion of pure white flowers that literally crowd the branches; exceedingly pretty and very hardy.

Double-flowering ( $D$. crenata $f l, p l$.). From Japan; flowers double, white, delicately margined with pink. This is deservedly one of the most popular and desirable flowering shrubs, and no collection can be complete without it.

Double White ( $D$. $a l b a f l$. $p l$.). Produces a profusion of double, pure white flowers; similar in habit to preceding.

Fortune's ( $D$. Fortunei). Dark green foliage, and large, single flowers. Their hardihood, luxuriant foliage and profusion of attractive flowers render the Deutzias deservedly the most popular flowering shrubs in our collection.

Pride of Rochester. Origin, Rochester, N. Y. Large, double, white flowers, the back of the petals being tinted with rose; excels most of the old kinds in flower and vigorous habit; quite early and very handsome.

Watereri. This variety is of recentintroduction: similar to Pride of Rochester, though in habit of growth they are more dwarf than the above. Very handsome.

ELDER, Golden ( Sambucus aurea). The golden yellow foliage of this variety is quite conspicuous on the lawn or where planted with other shrubbery; when the leaves first appear they are a bright green, soon changing to golden green. Will not produce the desired effect if planted in the shade. $\cdot$ 


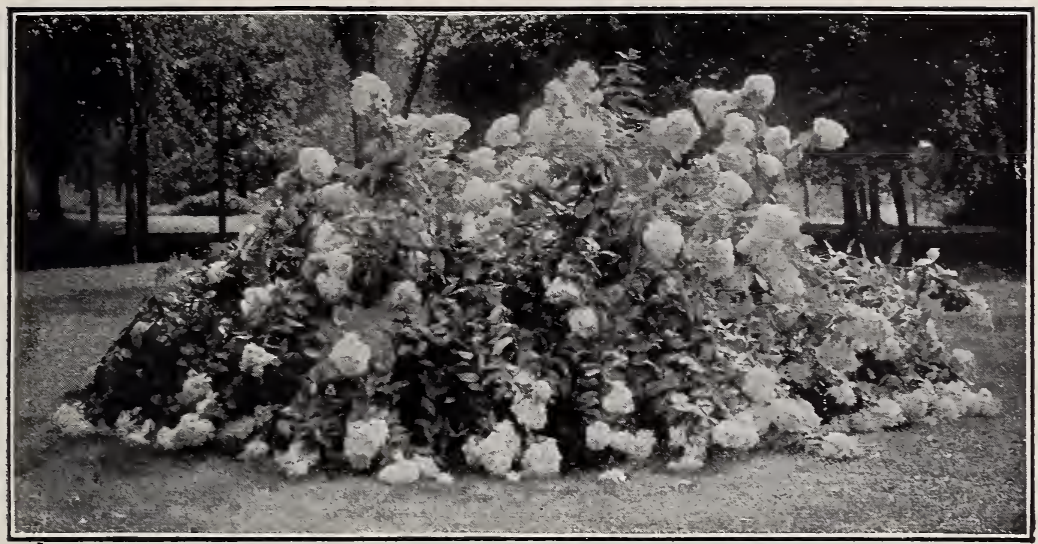

HYDRANGEA PANICULATA GRANDIFLORA (See page 5 8 )

FLOWERING AND OTHER SHRUBS, continued

ELAEAGNUS longipes. This has small, yellowish white flowers in May, followed by berries somewhat larger than currants, which when ripe, toward the close of June, are of a reddish amber color, and are very good for eating fresh or for cooking. The bush is also then quite ornamental.

Parvifolia. This one is generally understood when "Silver Thorn" is spoken of, though the name applies to all the species. It has sweet-scented yellow flowers, in great profusion, in May. The stems are clustered with mottled rell berries in July, which, while not equal to those of Longipes, are fairly good eating.

EUONYMUS Europaeus (Strawberry, or Spindle-Tree). An ornamental shrub of large size, whose chief beauty consists in its brilliant red berries.

EXOCHORDA grandiflora. Japanese origin. A superb shrub, furnisting clouds of bloom in May; the flower is large, pure white, in racemes of five or six, with spoon-shaped petals, which are very narrow and stand apart at the base; the bush is large-growing, attaining sometimes 10 feet in height and nearly as broad; hardy; a grand shrub, indeed.

EVERGREEN THORN (Cratcegus Pyracantha). A low, bushy plant, retaining its foliage all winter; has pinkish or white flowers, succeeded by dense clusters of orange-scarlet berries.

FORSYTHIA, Golden Bell ( $F$. viridis $\operatorname{sima}$ ). Flowers golden yellow, produced in the greatest profusion in the very early spring.

Fortune's ( $\boldsymbol{F}$. Fortunei). Growth upright; flowers golden yellow.

Weeping ( $\boldsymbol{F}$. suspensa). Growth slender and drooping; flowers yellow.

FRINGE, Purple (Rhus cotinus). Smoke Tree, Venetian Sumac, etc. A very elegant ornamental tree, or large shrub, with curious, hair-like flowers of pale purplish color that covers the whole plant.
Fringe, White (Chionanthus Virginica). See Ornamental Trees.

GOLDEN GLOW (Rudbeckia). A hardy perenuial, growing 6 to 7 feet high, and producing hundreds of bright golden flowers 2 to 3 inches in diameter, on long, graceful stems, forming immense heads of bloom. Fine for cut-Howers. Can be grown anywhere with very little care. Should be planted in erery garden, for when once well established will furnish an endless amount of flowers.

HAZEL, Purple-leaved European Hazel-nut (Corylus Avellana atro-pu)purea). A rigorous shrub, with deep purple leares.

HYPERICUM aureum (St. John's Wort). One of the finest in flower and foliage; continues in bloom from August to October. From Tennessee.

Kalmianum. Flowers bright vellow; blooms in midsummer.

Moserianum. A half-shrubby sort, almost evergreen when protected, bearing very large yellow Howers 2 inches in diameter, which are produced from July till late fall. One of the most desirable of recent introductions. 1 to 2 feet.

HALESIA tetraptera (Common Snowdrop, or Silver Bell). Very pretty white, bell-shaped flowers in the spring.

HONEYSUCKLE, Fragrant Upright. (Lonicera fritrantissima). Is almost an evergreen. Flowers cream-colored and very fragrant; continue for a long time. The following species are upright or shrubby plants. Climbing sorts belonging to this class will be found described under the heading of Climbers and Creepers.

Tartarian (Lonicera Tatarica). From Tartary; flowers abundant; rose-colored. White-flowering Tartarian (L. Tatarica $a l b a)$. Similar to the preceding, but with nearly pure white flowers.

Great Red-flowering ( $L$. rubra grandiflora). Of strong growth; flowers very abundant; deep rose; very attractive 


\section{FLOWERING AND OTHER SHRUBS, continued}

\section{HYDRANGEA}

The native species are handsome shrubs of medium size, with tine, large leaves, generally of a light green color, and perfectly hardy. The introductions from Japan and China are particularly interesting and valuable. H. paniculata grandiflora is remarkable in foliage and flower, and, being perfectly hardy, is of great value. 'The other Japanese varieties, like the $I I$. hortonsis, require protection in winter. They should be grown in pots or boxes and wintered in the cellar, and in the summer placed along walks under the shacie of trees. $H$. Otaksa is especially adapted for this purpose.

Garden ( $H$. hortensis). Hardy, foliage large; flowers produced in large, globular greenish heads, changing to light rose-color.

Oak-leaved ( $H$.quercifolia $)$. Leaves large, turning to crimson in the autumn; flowers white, changing to purple.

Large-panicled ( $I$. paniculata grandiflora). 'This is one of the very finest slirubs of recent introduction, growing 8 to 10 feet high, produeing immense pyramidal panicles of white flowers more than a foot long; blooms in Aug. and Sept.; indispensable.

Tree or Standard Form. Same as above but grown as standard instead of bush form.

Thomas Hogg. An attractive variety, with enormous heads of pure white flowers; recently introduced from Japan.

Otaksa. From Japan; immense trusses of rose-colored flowers in June.

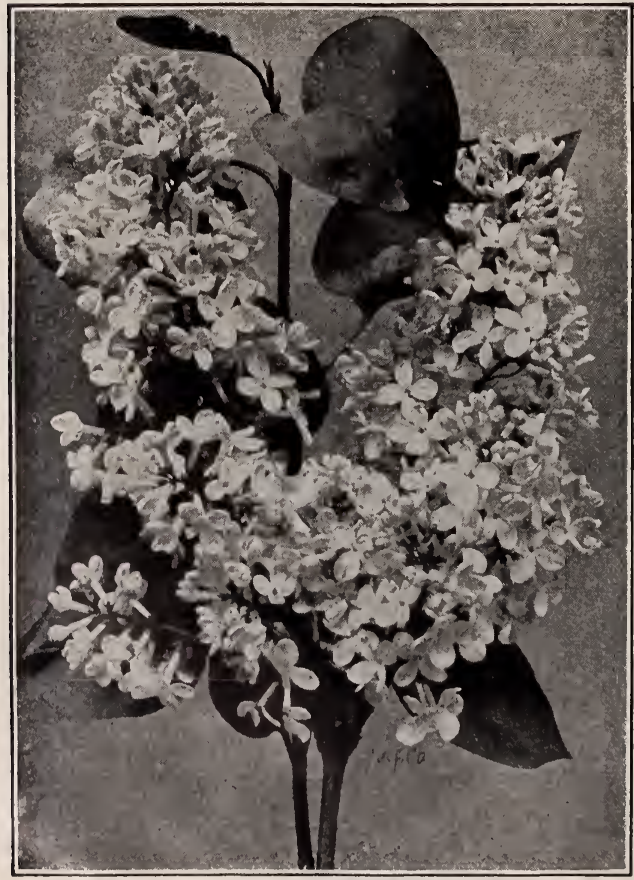

LILAC, CHARLES $\mathrm{X}$ DEUTZIA
HOP TREE (Ptelea trifoliata). This does not advance much beyond the shrmb size. It bears clusters of white flowers in June, followed by hop-like seeds in the fall.

Aurea. Same as the above, but with golden foliage. 12 to 15 feet.

INDIGO BUSH (Amorpha fruticosa). A fine slirub, with long, slender spikes of dark violet flowers; very pretty.

IRIS Kaempferi (Japanese Iris). The Howers of these Irises grow to an enormous size, averaging 6 to 8 inches in diameter, while the beauty and variety of the coloring surpasses description. They sloould be planted in rich soil, and will succeed in any situation except shade.

JAPAN QUINCE (Pyrus Japonica, Cydonia Japonica, etc.). Produces bright scarlet flowers in great profusion in the early spring; very attractive and hardy; one of the very best hardy shrubs in the Catalogue.

White-flowering ( $C$. Japonica alba). A desirable shrub, producing delicate white and blush flowers in early spring.

KERRIA Japonica (Japan Globe-flowered Corchorus). A flexible green-branched slirub, producing for sereral months double globular yellow flowers.

\section{LILACS}

Well-known beautiful shrub, indispensable in every collection. They Hower in May. The Double Lilacs are heavier and more massive, and trusses of bloom larger than the single varieties.

Common (Syvinga vulgaris). Very generally known and admired, with its profusion of fragrant bluish purple flowers.

Charles X. A strong, rapid grower, with large, shining leaves and reddish purple flowers.

Double (S'. Lemoinei flore pleno). A new and choice variety of the Lilac, producing long racemes of double purple Howers, lasting longer than the single sorts. Valuable.

Common White (S. alba). Flowers produced in slender panicles; pure white and fragrant.

Japan, or Tree (S. Japonica). A large-growing kind; panicles of white flowers. Foliage deep green.

Louis Van Houtte. Large panicles of red flowers.

Lilac of Marley ( $S$. de Marley). Flower's of reddish purple, borne in great profusion.

President Grevy. A beautiful blue; individual. Very double and very large; one of the finest Lilacs.

Sanget's (S. Sangeana). Purplish red; flowers very fine.

Souvenir de la Spath. The most distinct and beantiful variety in the collection. Trusses immense; very compact; florets very large, deep purplish red. Growtli vigorous.

White Persian (S. Persica alba). The flowers are nearly white, being slightly shaded with purple. 


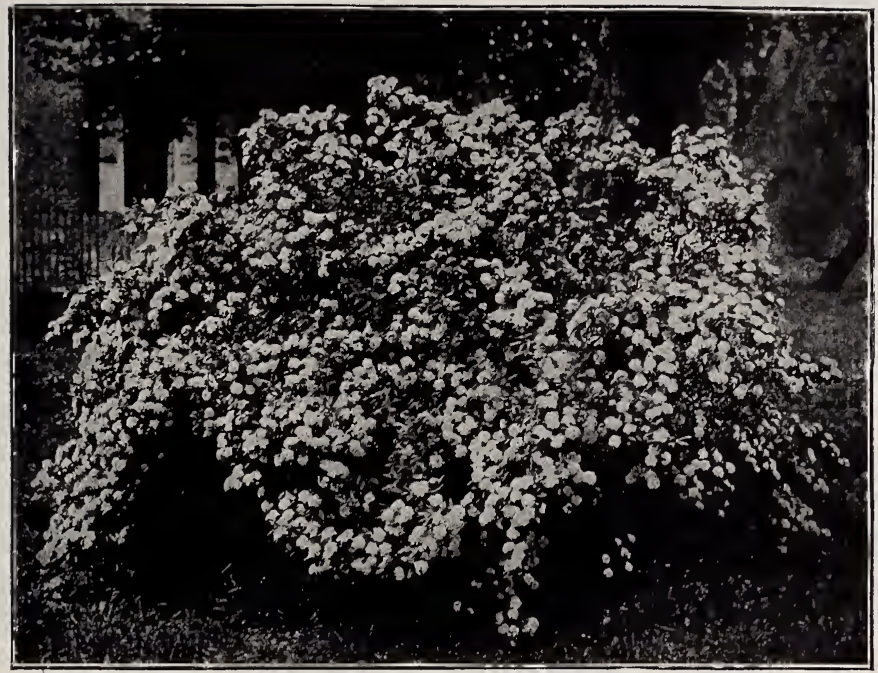

SPIRAA VAN HOUTTEI (See page 60)

\section{FLOWERING AND OTHER SHRUBS, continued}

PRIVET (Ligustrum). The Privet in all its varieties deserves attention as an ornamental plant. It is almost an evergreen, and grows freely in all soils; is compact and regular in its form, and bears shearing to any extent. The whole collection which we offer makes an interesting group on the lawn; flowers appear in June and July.

Ovalifolium (California). A vigorous, hardy variety, of fine habit and foliage, nearly evergreen; grows well in almost every soil; ornamental, and one of the best hedge plants.

Variegata. A variety of the Vulgare, the foliage of which is streaked with yellow.

PEONIES, Herbaceous. These are very beautiful, showy and easily cultivated plants, blooming from the beginning of May to the end of July. They should have a place in every garden. A selection will give a continuous bloom for three months. We offer the best sorts in assorted colors.

Tree Peony (Pronia Moutan). The varieties are handsome flowering shrubs, attaining 5 to 8 feet in height; flowers very large and quite numerous, with gorgeous colors.

PERENNIAL PEA (Lathyrus grandiflorus). Similar to the sweet pea, but has pink and white flowers in large clusters.

PLUM, Double-flowered (Prunus tri$l o b a)$. Of recent introduction from China; a very hardy shrub; flowers semi-double, of a delicate pink, closely set along the branches, forming a compact spike; very pretty and desirable.

Purple-leaf ( $P$. Pissardi). One of the very best small trees or shrubs of recent introduction; the foliage is a beautiful red-purple, changing to a deep, blackpurple; the hot sun has no ill effect on.
Purple-leaf Plum, continued

its rich colors; it remains beautiful until frosts come, something unusual in purple-leaf plants; by far the best of its kind; exceedingly hardy and very easy to transplant.

SIBERIAN PEA (Caragana arborescens). A large shrub with bright yellow, peashaped flowers.

\section{SPIREAS}

Beautiful shrubs of the easiest culture; very desirable for shrubberies or the flower garden.

Anthony Waterer (Crimson Spirea). Color briglit erimson. It has a very dwarf and dense growth; blooms all summer and fall; it also makes a beautiful pot-plant.

Billard's (S. Billardii). Bright rose-colored flowers; blooms nearly all summer; desirable.

Billard's White (S. Billardii alba). Very similar to the rose-colored, but with blossoms pure white.

Blue Spirea (Caryopteris Mastacanthus). Small violet or lavender-blue flowers; late summer and autumn. Very desirable.

Fortune's ( $S$. callosa). A fine sort; flowers light pink, produced in large panicles; blossoms nearly all summer.

Fortune's Dwarf White ( $S$. callosa alba). A new dwarf variety, with pure white flowers.

Golden-leaved (S. opulifolia aurea). Very conspicuous from the golden yellow hue of its foliage. June.

Plum-leaved, Bridal Wreath ( $S$. prunifolia flore pleno). A very beautiful variety; flowers pure white, small and very $x=$ ia. ${ }^{2}$ ooms very earlv 


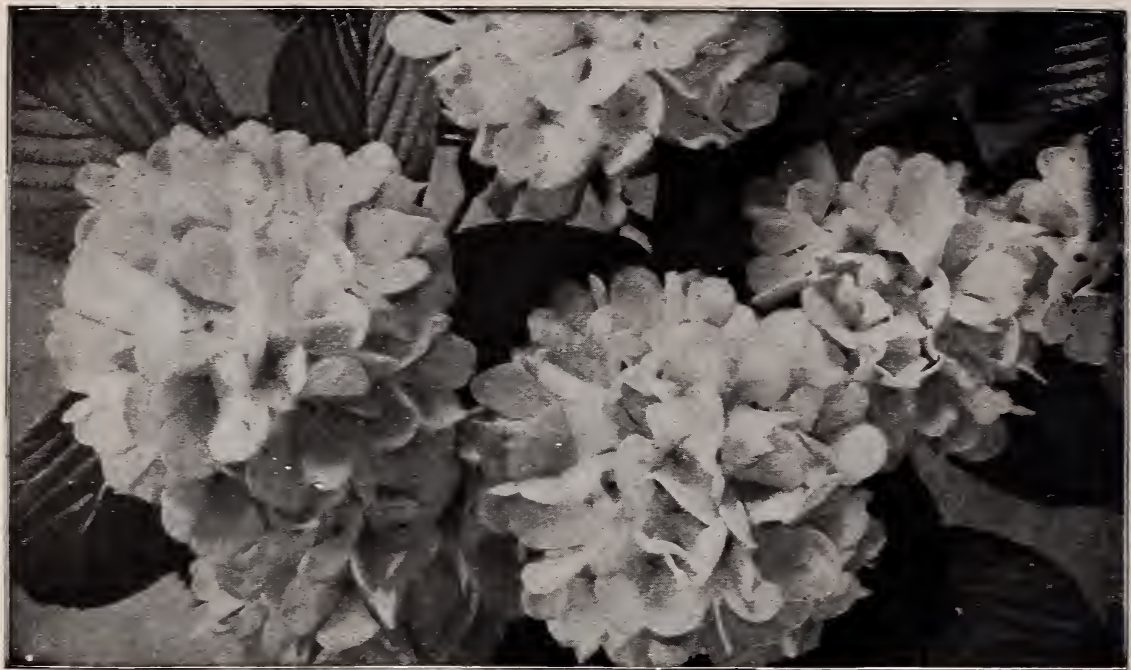

VIBURXUM PLICATLM (SNOWBALL)

\section{FLOWERING AND OTHER SHRUBS, continued}

Spirea, Reeves' (S.Reeresii, or lanceolata). A very pretty sort, producing clusters of white flowers that corer the whole plant.

Reeves' Double-flowering ( $S$. Reevesii flore pleno). This is one of the handsomest of the Spireas; flowers pure white, very double; indispensable.

Thunberg's ( $S$. Thunbergii). A small, white-flowering variety; desirable for pot culture.

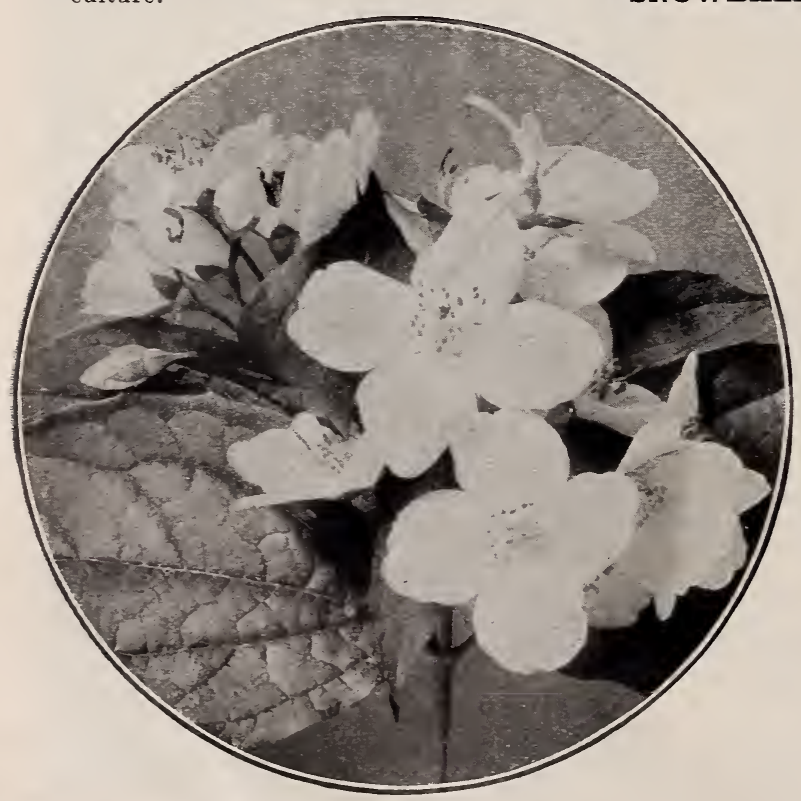

MOCK ORANGE (See opposite page)
Spirea Van Houttei.The grandest of all the Spireas; it is a beautiful ornament for the lawn at any season, but when in Hower is a complete fountain of white bloom, the foliage hardly showing. Clusters of twenty or thirty flat white florets make up the raceme, and these clusters are set close along the drooping stems. Perfectly hardy, and an early bloomer.

SNOWBALL (Tiburuum Opulus). Cranberry Bush. An old and well-known shrub, bearing large balls of pure white Howers; rery decoratire fruit, which begins to color about midsummer hangs on during the winter. It is claimed that the English Sparrows will not eat the berries. The foliage, like that of all the Viburnums, gets rers pretty in the autumn.

Single (I. tomentosum). A single form of Snowball: has white flowers, but the attractireness of this shrub is its purple foliage in autumn.

Japanese ( $I$. plicatum). A rare and exceedingly beautiful species from China; flowers in large, globular heads, pure white, hanging long on the bush: a rery choice and desirable shrub.

S N O W B ER Y, Pink (Symphoricarpus race. mosus). Flowers in summer: quantities of large, white waxen berries in autumn. 


\section{Fruit and Ornamental Trees, Shrubs, Etc.}

\section{FLOWERING AND OTHER SHRUBS, continued}

Snowberry, Red ( $S$. glomeratus). Compact form; small red berries in autumn.

SUMACH, Cut-leaved ( Rhus glabra laciniata). A very striking plant, of moderate size, with deeply cut leaves resembling fern leaves; dark green above and glaucous below, and turning to a rich red in autumn.

\section{SYRINGA, or MOCK ORANGE (Philadelphus)}

Of vigorous habit; very hardy, with large, handsome foliage and beautiful white flowers, produced in the greatest profusion in the blossoming season. It merits a prominent place in all collections of shrubbery. It is called the Mock Orange because its flowers somewhat resemble orange blossoms, and are equally fragrant, though with not so delicate a perfume. Most of the varieties, except those of dwarf habit, form large-sized shrubs, 12 to 15 feet high. They can, of course, be kept smaller by pruning. The dwarf sorts do not yield many flowers, but are very pretty, compact plants, and are very useful where small shrubs are desired. All of the varieties flower in June, after the Weigela. By planting the lateflowering sorts, the season may be considerably extended.

Double - f l ow e ring ( $P$ flore pleno). A rariety with partially double, fragrant flowers.

Garland ( $P$. coronarius). A well-known shrub, with pure white, highly scented flowers. One of the first to flower.

Gold-leaf (Philadelphus aureus). A d war variety. Flowers abundantly. A handsomely shaped plant, of medium size, with bright, golden yellow foliage. Will be found valuable for creating pleasing and striking contrasts with shrubs of other colored foliage.

Grandiflorus. A large-flowered, stronggrowing sort, and perhaps the best of all.

Lemoinei erectus. The flowers of this species are more clustered than the older sorts. Flowers very sweet. Four to 6 feet.

Nepalensis ( $P$. variegata). A variety similar to $P$. grandiflora, but blooms later.

Nivalis. Stamens cream color; the whole flower is a delicate white.

Sweet ( $P$. coronarius). Strong-growing, rounded habit. A pure white, very fragrant, late-flowering variety.

TAMARIX. These are very beautiful shrubs, with small leares, somewhat like those of the Juniper, and delicate small flowers in spikes. They are invaluable for planting by the seaside, where scarcely anything else will grow.
Tamarix Africana (African Tamarisk). A tall, graceful shrub, with small foliage like the Juniper, and delicate, small, rosy purple flowers, produced in spikes; very pretty.

Tetranda. The most beautiful of the genus, flowers pale pink; blooms late in summer.

\section{WEIGELA}

Hardy, easily grown, and great bloomers. Of erect growth while young, but gradually spreading and drooping as they acquire age. They produce, in June and July, superb, large, trumpet-shaped flowers of all shades and colors from pure white to red. In bor- 


\section{FLOWERING AND OTHER SHRUBS, continued}

Weigela Hendersoni. Of fine compact habit, rather slender, erect growth; flowers medium size; outside of petals red, interior a lighter shade.

Hortensis nivea. Flowers pure white, retaining their color, and being clear enough for the choicest bouquets; foliage large; a profuse bloomer; of dwarf,spreading habit. 3 to 4 feet.

Lavallei. A fine variety, producing dark reddish purple flowers; one of the darkest varieties; habit straggling.

Lovely Weigela ( $W$. amabilis, or splendens). A showy variety of vigorous growth, blooming late in the season. Very desirable.

Rosea. An elegant shrub, with fine rosecolored flowers. Introduced from China by Mr. Fortune, and considered one of the finest plants he has discovered. Quite hardy; of erect, compact growth. Blossoms in June.

Sieboldi alba marginata. Of upright habit. When the leaves are young the variegation is yellow; when they mature it becomes silvery white; flowers rose-colored. A splendid and effective variegatedleaved shrub.
Weigela Stelznerii. Flowers dark red; a profuse bloomer.

Variegated. The leares of this variety are strikingly marked with white, yellow and light green. The flowers are light rosecolored.

Van Houttei. A new variety of vigorous growth with dark rich crimson flowers, produced in great abundance. A decided acquisition.

WAYFARING TREE (Viburnum L $a$ $\tan a)$. A large, robust shrub, with soft, heavy leaves and large clusters of white flowers in May, succeeded with red fruit; retains its foliage very late. In some localities it is almost an evergreen and adds a picturesque touch to the lawn even in winter.

YUCCA filamentosa (Adam's Needle). Perfectly hardy and easily grown. The stem on which the flowers are borne is thrown up in July, and forms a perfect pyramid of creamy white, bell-shaped flowers. Very picturesque effects are produced when planted in groups on the lawn. The foliage retains its color until late in the winter and is very effective at that time.

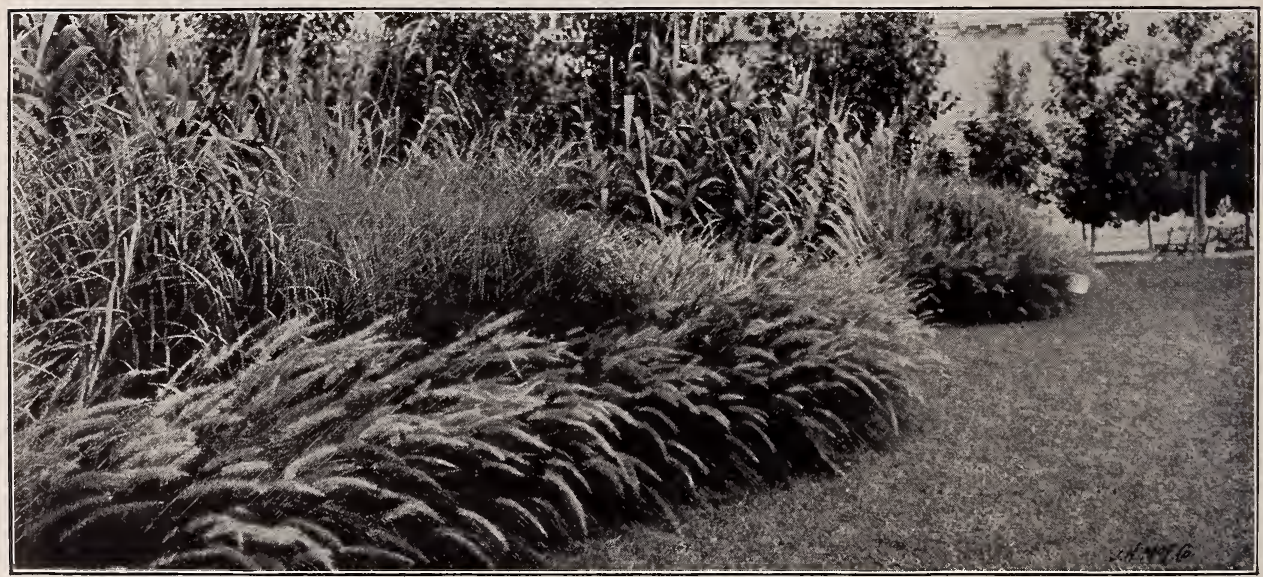

\section{ORNAMENTAL GRASSES}

These beautiful hardy Grasses are deserving of the highest commendation. For the garden they are invaluable, being very showy and ornamental and of easy cultivation. They should be in every collection.

EULALIA Japonica variegata. Handsomely variegated leaves.

Japonica zebrina (Zebra-striped Eulalia). One of the most beautiful of Ornamental Grasses; foliage marked crosswise with bands of white and green.

ERIANTHUS Ravennae. A vigorous grower with large plumes.

PAMPAS GRASS (Gynerium argenteum). Grows in large, thick tussocks; has silvery, plume-like spikes of flowers; the most popular of all the Grasses. 


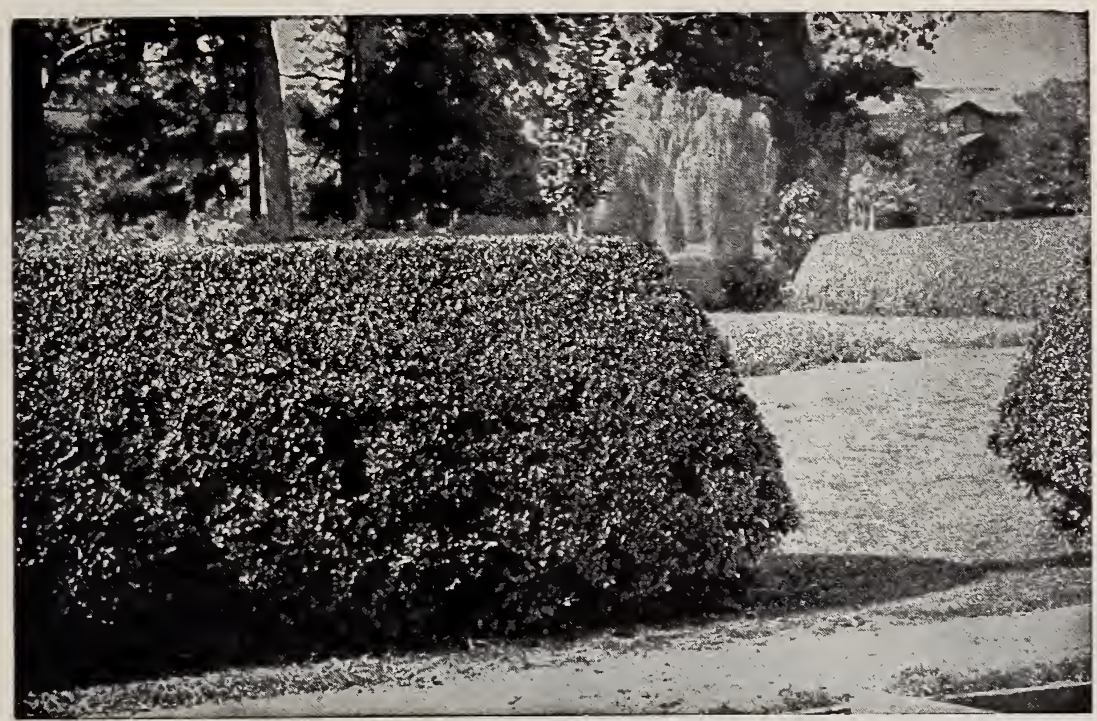

CALIFORNIA PRIVET HEDGE

\section{HEDGE PLANTS}

To secure a good hedge it is necessary to plant well. Dig a wide, deep trench, and work the soil thoroughly into the roots. Settle the ground firmly, so that each plant will be set as solidly as a post, then mulch heavily with some coarse material for a distance of one or two feet on either side, according to the size of the plants. This is especially necessary with evergreens, and all exposure of the roots to the sun and air must be strictly avoided. Evergreens should not be planted in the fall.

\section{EVERGREEN}

ARBORVITAE, American. One of the most desirable evergreen hedge - plants. Of very attractive appearance. Although a fast grower, it can be kept trimmed to any height desired. Best adapted for screens or windbreaks.

EVERGRE EN THORN (Cratcogus Pyracantha). A valuable plant for growing singly or for hedges. Attractive, rich, glossy foliage. When of mature age produces fragrant white flowers, succeeded by bright, orange-red berries.

SPRUCE, Hemlock. Desirable and ornamental. Nothing handsomer for hedges; sheared, compact and bushy.

Norway. A popular variety. Makes a very dense, compact hedge. Desirable for a firm hedge, to take the place of a fence.

\section{DECIDUOUS}

ALTHEA. Is much used in many localities for ornamental hedging. It can be sheared into any shape, and is very showy, either when the entire hedge is of one color or when assorted colors are combined.

BERBERIS Thunbergii. Beautiful dwarf Barberry from Japan. Has small, bright green foliage, changing to red in fall.

OSAGE ORANGE. The well-known and extensively planted thorn hedge of the present day. The cheapest hedge-plant we know of. Makes a strong, durable
Osage Orange, continued

fence; though not so ornamental as the other kinds, yet when elosely trimmed it is quite attractive.

PRIVET, California. Nothing in the way of a hedge-plant has attained in so short a time the popularity of the California Privet. While in this latitude it is deciduous, yet it retains its foliage until rery late in the fall or early winter. The flower is creamy white and very fragrant. It is certainly a most desirable thornless, hardy hedge-plant, with beautiful dark green foliage. It can be kept at any desired height by frequent trimming, and grows well at the seashore.

JAPANESE HARDY ORANGE (Citrus trifoliata). This valuable new fruit from Japan, after thorough testing, has proved itself entirely hardy in any part of the United States; it has borne regularly here for several years. The fruit, while not to be classed with first-class Florida oranges, is nevertheless attractive and raluable; it is of small size, and much like the ordinary orange; the flavor is good, subacid, very sprightly; valuable to use in place of the lemon, and is ele. gant to preserve. Beautiful ornamental shrub and an elegant hedge-plant.

JAPAN QUINCE. (Pyrus Japonica, Cydonia Japonica, etc.). Produces bright scarlet flowers in great profusion in the early spring. 


\section{CLIMBERS AND CREEPERS}

AKEBIA quinata. A climbing plant from Japan, with fine foliage and clusters of purplish, fragrant flowers; very pretty.

AMPELOPSIS quinquefolia (American Ivy, or Virginia Creeper). A native rine of vigorous growth, with abundant foliage, which turns rich crimson in the autumn; suitable for covering walls or trunks of trees.

Veitchii (Veitch's Ampelopsis). Recently introduced from Japan; grows rapidly and attaches itself firmly to walls; leaves small, turning to brilliant red in autumn.

ARISTOLOCHIA Sipho (Dutchman's Pipe). The common name comes from the resemblance of the flowers to an oldstyle pipe. The leaves are very large.

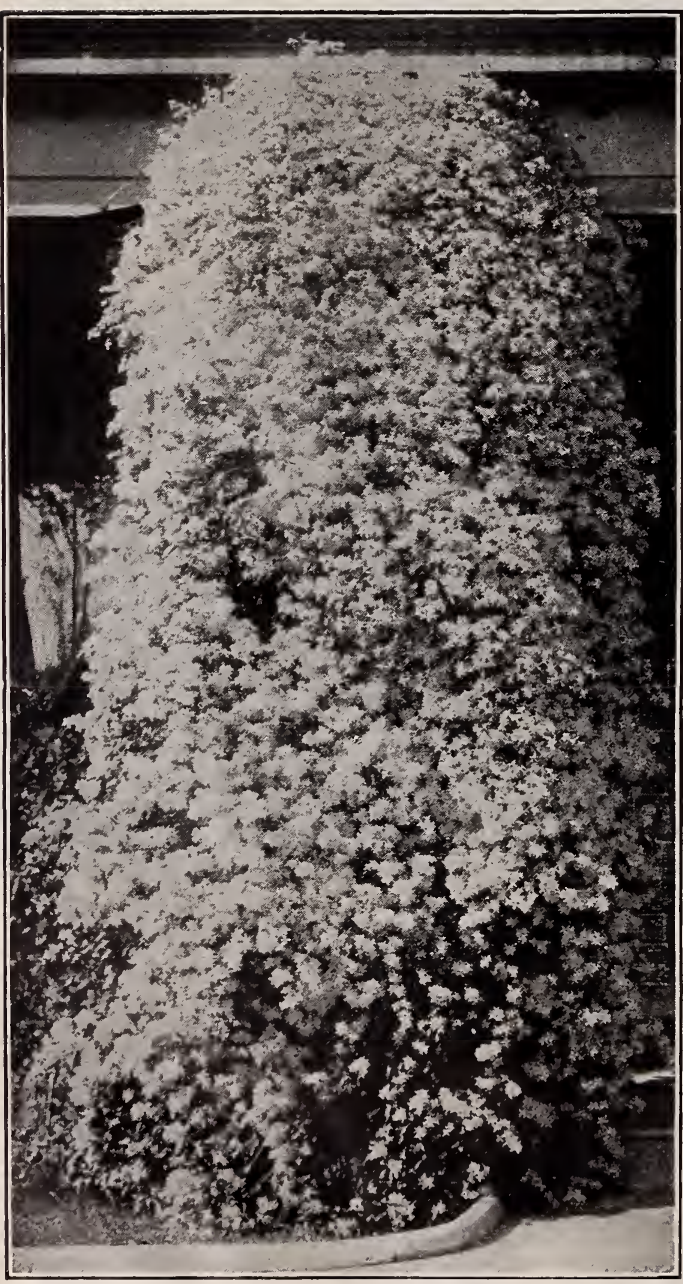

CLEMATIS PANICULATA

\section{CLEMATIS (Virgin's Bower)}

This is unquestionably one of the handsomest classes of vines for covering arbors, trellises, pillars, etc., that has been introduced. They are slender-branched, rapid growers, with handsome foliage and beautiful flowers, ranging in color from white to deep purple.

Duchess of Edinburgh. This is without doubt the best of the pure whites. Deliciously scented.

Flammula, or European Sweet-scented. A rampant grower; very hardy, bearing masses of small white flowers from June to September; very fragrant and beautiful.

Henryi. Very large,free grower and bloomer; flowers creamy white; one of the best.

Jackmani (Jackman's Clematis). Without a doubt the best yet introduced, and a general favorite; large velvety, dark violet-purple, strong and hardy.

Madam Edouard Andre. A handsome new red Clematis with large flowers of a beautiful velvety red. A free and continuous bloomer. It is destined to become as popular as the Jackmani Purple.

Paniculata. This valuable white Clematis, a nutive of Japan, has, after a thorough trial of several years, proved entirely hardy. The deep, clear, green foliage is unusually broad and healthy, and remarkably free from all insect enemies. The flowers are pure white, often slightly tinged with cream, from three-quarters to an inch in diameter, star-shaped, and with a most pleasing and penetrating fragrance. They are borne in heads, on stiff stems 4 to 6 inches long from the axils of the leaves. The fragrance is remarkable in its intensity, and is noticeable quite a distance. For any situation where a rapidgrowing climber is needed, this will be found a very valuable plant. The late season of bloom. ing is a strong point, as most other climbers have passed their flowering stage by the middle of August, when this is just coming to perfection, and continues blooming nearly a month.

Scarlet $(C$. coccinea). Flowers brilliant scarlet; unlike any other Clematis; very choice and rare. Blooms in July.

White Jackmani (C. Jackmani $a(b a)$. Similar to the purple in growth and habit, but with pure white flowers. It is a most beautiful and graceful corering for the trellis and porch, and is perfectly hardy. 


\section{HONEYSUCKLE}

\section{(Lonicera)}

This includes some of the most desirable climbing plants that can be used for covering arbors und porches.

Golden-veined ( $L$. brachypoda aureo-reticuluta). A handsome and desirable va riety, with elegantly veined and netted foliage.

Hall's New Japan ( $L$. Halliana). A strong, vigorous evergreen sort; flowers white changing to yellow ; very fragrant, and is covered with flowers nearly all summer and autumn; the best of all the Honeysuckles.

Red Coral, or Scarlet Trumpet ( $L$. semperirens). A common native vine, producing scarlet inodorous flowers through the summer.

IVY (Hedera). The Ivies are evergreens, and in $\mathrm{u} \mathrm{ch}$ used for covering walls, trees, etc., clinging tenaciously thereto. They generaliy succeed best in a cool or somewhat shaded place. We grow the most desirable sorts.

J E S S A M I N E, Naked-

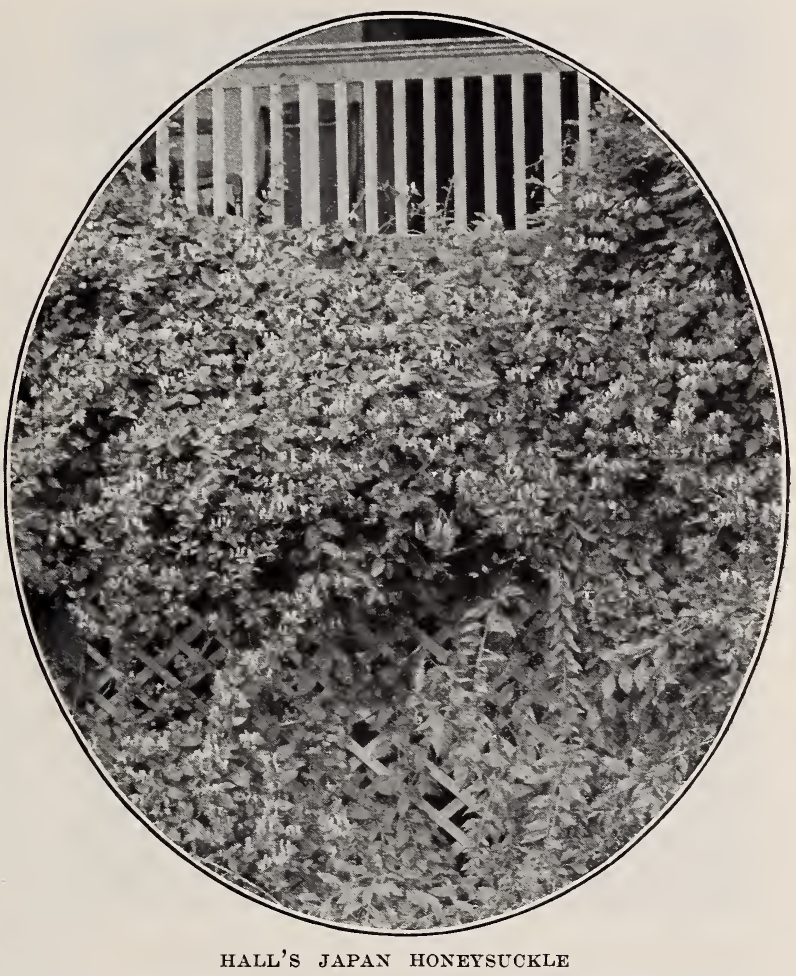
flowering (Jasminum mudiflorum). Produces golden yellow flowers very early in the spring, before the foliage appears.

Common White ( $J$. officinale). A popular climber, with very fragrant white flowers.

Fructicans. Yellow flowers; shrubby growth.

Grandiflora (Large-flowered Trumpet Creeper). Blooms orange-red.

TRUMPET FLOWER (Bigonia radicans). A rapid-growing native plant, with large,

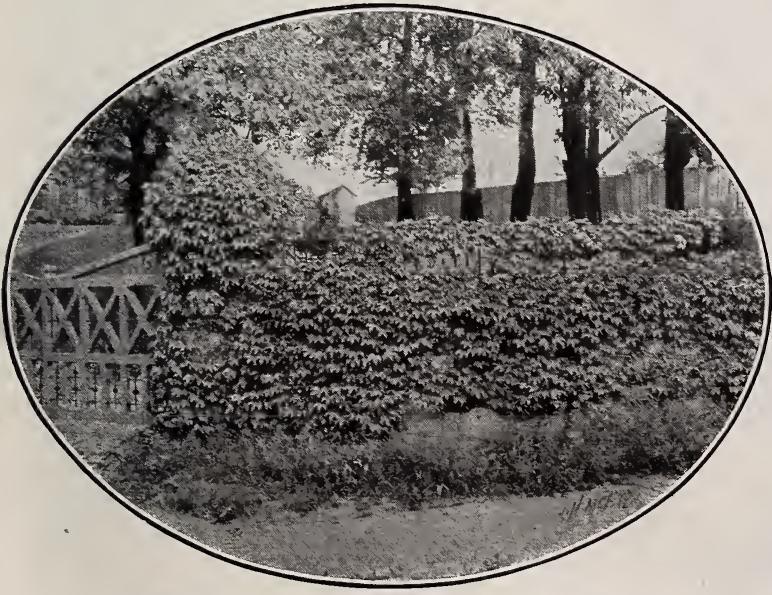

AMPELOPSIS VEITCHII (See opposite page) trumpet-shaped scarlet flowers.

WISTARIA, Chinese ( $W$. Sinensis). One of the most elegant and rapid-growing of all the climbing plants; attains a very large size, sometimes growing 15 or more feet in a season; has long racemes of pale blue flowers in spring and sometimes in autumn. A Wistaria adds an indefinable touch of grace and beauty to the plainest porch.

Double Purple ( $W$. flore pleno). The habit of this plant is similar to the preceding; flowers verydouble, and deeper in color than the former.

White-flowering ( $W$. al$b a)$. Like the preceding, except that the flowers are pure white and single. 


\section{ROSES}

The Rose has long been acknowledged as the "Queen of Flowers," No flower yet introduced compares at all with the Rose in exquisite beauty and fragrance, and no word of praise can add to its charms. We aim to keep on hand a good supply of only the very best varieties, such as will bloom freely and give satisfaction.

Roses of the Tea and Monthly class are not altogether hardy north of Virginia, yet with careful banking of the earth high around the plant most kinds will do well. The Hybrids, Mosses and Clusters are more hardy, still some protection is very beneficial to these, if it only be a covering of loose straw or leaves. Coarse stable manure is the best mulch for winter and summer. We would recommend that, north of Virginia, selections should be made from the Hybrid Perpetual class, and especially where complete hardiness and large plants are desired. Spring is the best time for planting Roses. The soil should be rich and well drained, with careful culture, to insure success. Annual pruning is rery beneficial. Our Roses are all grown on their own roots outdoors and will transplant with much better satisfaction than the tender hothouse plants.

The Baby Rambler, or Dwarf Everbearing Crimson Rambler

A cross between Crimson Rambler and a Polyantha Rose. It has large trusses of crimson flowers like the Crimson Rambler, but instead of being a climber is of dwarf, compact habit with dark green foliage, and is perfectly hardy and blooms continually through the season.

\section{TEA AND MONTHLY ROSES}

The Tea Roses may well be considered the highest type of the Rose in color, fragrance and grace of form. All Teas bloom freely throughout the season.

Bon Silene. Brilliant carmine-rose, richly tea-scented; a well-known favorite.

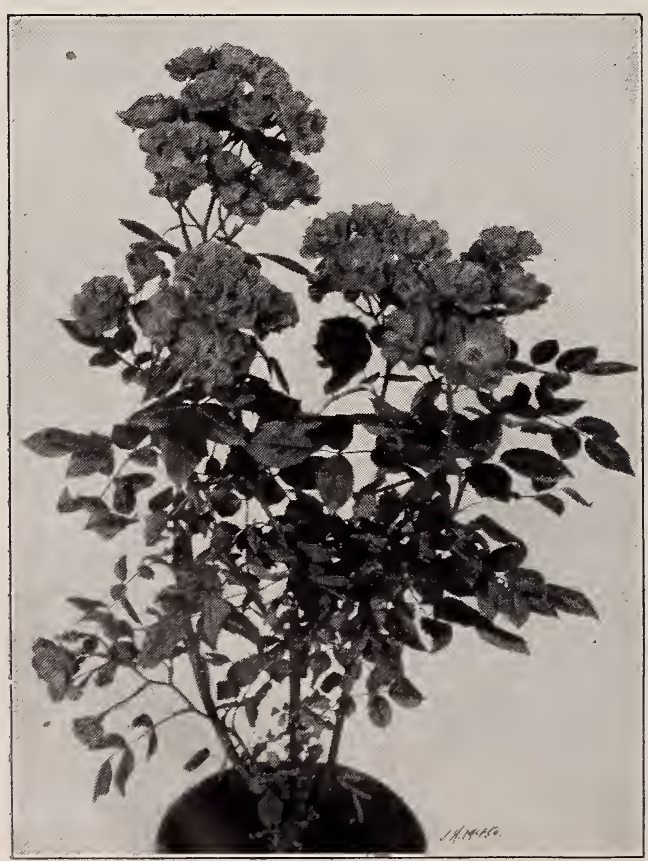

THE BABY RAMBLER
Bridesmaid. Famous everywhere. Magnificent buds and flowers. Color clear, dark pink.

Catherine Mermet. Bright flesh color: full and beautiful; one of the most lorely of its color.

Coquette de Lyon. Light canary yellow; a most desirable bedding variety.

Cornelia Cook. Hard to beat. Pure creamy white, tinged with lemon and blush. Perfect.

Duchesse de Brabant. Few Roses equal this in freedom of flowering; none surpass it in either fragrance or vigor; the flowers are rather loose when open, but are rich and peculiarly colored; color rose, heavily shaded with amber and salmon.

Etoile de Lyon. Fine striking sulphuryellow; the most raluable yellow for summer bedding.

Golden Gate. This is a beautiful free-blooming and healthy Tea Rose that we can recommend to everyone desiring large flowers, long stems and continuous bloom. The buds are long and pointed, opening out into a wellshaped flower of creamy white, delicately tinged golden yellow and rose.

Golden Sun (Soleil d'Or). This is a splendid new hardy yellow Rose, suitable for garden planting. Seems to be a cross from the old Persian Yellow with a bright red hybrid perpetual. It makes a strong, vigorous growth. The flowers are extra large, full and deep and delightfully sweet. The color is an exquisite shade of chrome yellow, beautifully tinged and colored with bright orange and nasturtium-red; exceedingly beautiful. The bush is eñtirely hardy, needs no protection and blooms abundantly erery season; it will be a permanent ornament for your lawn or garden for years. Golden Sun has taken the highest prizes wherever exhibited, both in this country and Europe, and is a most valuable acquisition to our list of Hardy Garden Roses.

Gruss an Teplitz. One of the brightest-colored Roses grown. When first opened it is dark rich crimson, quickly changing to bright scarlet, shading to relvety fiery red. Blooms continually; flowers good-sized and delightfuliy fragrant. Plant vigorous and upright, making fine pot-plants. 


\section{TEA AND MONTHLY ROSES, continued}

Ivory, or White Golden Gate. Golden Gate has become so well known to all rose growers as an extremely free forcing variety of the largest size, that all will understand what the new Rose Ivory is like, when it is described as a White Golden Gate, a sport from that variety. Its extraordinary freedom, large size, heary canes, all tend to make it a valuable white variety for cutflowers. Strong plants.

Isabella Sprunt. One of the grandest old Roses in cultivation. Splendid large flowers of bright canary-yellow.

Kaiserin A ugusta Victoria. Celebrated the world over for its elegant, large, pointed buds and large, full, double flowers. Color delicate, creamy white. Deliciously fragrant. Particularly hardy, and one of the most beautiful Roses in cultivation for open ground culture.

La Reine. A beautiful, clear, bright rose, fine, full form, very fragrant. It is well named "The Queen."

Madam C. Testout. A really grand Rose of the La France type but larger and of better color. It is clear pink-there is nothing in the Rose line that can approach it in color-and the flower is as large as Baroness Rothschild and as free as La France. Very fragrant; a magnificent forcing variety.

Maman Cochet. Deep rose-pink, inner side of petals silvery-rose, very double; an exquisite Rose in every way.

Meteor. A rich dark velvety crimson $\mathrm{Hy}$ brid Tea; free-blooming and vigorous grower.

Perle des Jardins. The queen of all yellow Roses. Color is clear golden yellow, indescribably rich. Immense, full, double and globular flowers; exquisitely beautiful.

Papa Gontier. One of the best crimson Roses, with immense buds and magnificent large bold flowers.

Pink La France. Famous the world over. One of the loveliest and sweetest of all Roses. Perfect buds and flowers. Color silvery pink, tinged with crimson. Deliciously sweet.

Safrano. Saffron and apricot; one of the oldest and best Roses; in the bud shape it can hardly be surpassed.

The Bride. Most popular white Rose for winter flowering. Flowers large and double, on long stiff stems, of fine texiure and substance; last a long time in fresh state after being cut. During extreme hot weather it becomes a pinkish white, at other times a beautiful pure white.

White Maman Cochet. For open ground planting cannot be surpassed. Superb, large, deep and double flowers. Color snow-white, sometimes tinged with pale blush.

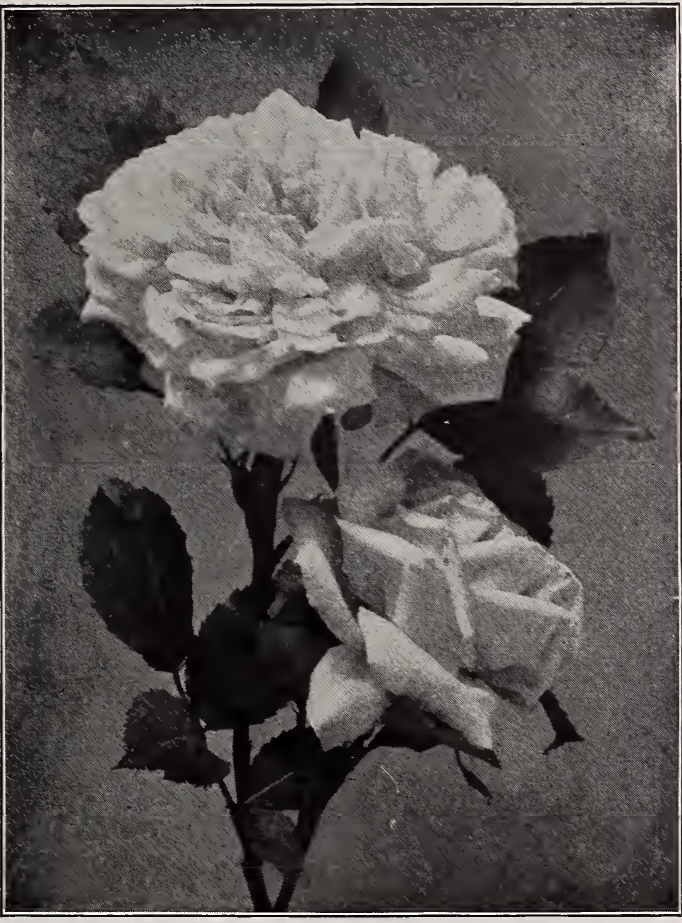

TYPE OF TEA ROSE

Yellow Cochet, or Madame Derepas Matrat. A pure Tea Rose, very free-growing and hardy in character, withstanding ten degrees below zero. It throws up fine, strong stems, crowned by solitary buds of grand size; the color is a good sulphur-yellow, blooms very large, perfectly double, splendid form and freely produced. It has every quality necessary to make the ideal yellow bedder, ranking with the White and Pink Cochets in value as a Summer Rose.

BENGAL, or CHINA ROSE, HERMOSA

Undoubtedly the best pink bedding Rose in cultivation; an old favorite

\section{HARDY HYBRID PERPETUAL ROSES}

These are considered the most valuable of all hardy plants. They are distinguished by their vigorous, upright growth and large, bold flowers, frequently measuring 4,5 and 6 inches in diameter. Entirely hardy in all parts of the country, living through the most severe winters, with a light protection of leaves or coarse manure. They bloom the second year when fully established, and should be planted in the open ground. Our collection includes the finest rarieties in cnltivation.

American Beauty. A grand Rose for either forcing. or outdoor culture. Its very double flowers are of a deep crimson color 


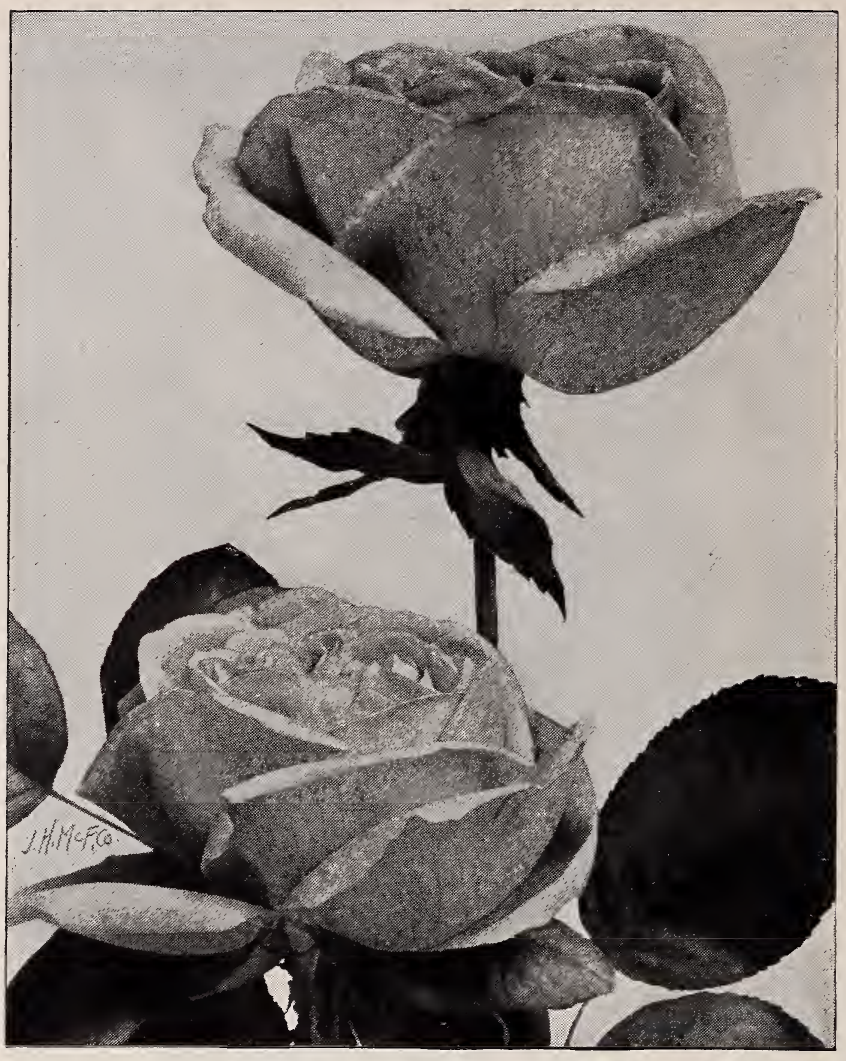

AMERICAN BEAUTY (See page 67)

Magna Charta. Extra large, full flowers, very double; finely formed; color clear rosy red, beautifully flushed with violet-crimson. None better.

Marshall P. Wilder. Col or bright cherry - carmine, fragrant, of vigorous growth, with fine foliage. One of the freest of the H. P's to bloom; we can recommend this Rose without hesitation.

Mrs.John Laing. Delicate pink, with satin tinge.

Paul Ne y ron. Very large dark Rose; by far the largest Rose in cultiration: one of the most desirable.

Prince Camille de Rohan. Deep velvety crimson-maroon, shaded with red.

Ulrich Brunner. Extra large, bold, full, globular flowers; rich crimson, tlamed with scarlet.

\section{MOSS ROSES}

Who does not admire Moss Roses? Their mossy buds are

HARDY HYBRID PERPETUAL ROSES, con. and very fragrant; it is of full and quite perfect form, with the petals finely imbricated; a constant bloomer and strong grower. Very desirable in every way; its rich "June-rose" scent would alone commend it, to say nothing of its many other good qualities.

Anne de Diesbach. Clear bright carmine; very large and finely sliaped; full and fragrant.

Coquette des Alps. White center, shaded rose; of fine form, full center.

Coquette des Blanches. Pure white, large and globular.

Fisher Holmes. Rich velvety crimson; large, double and of fine form.

General Jacqueminot. Too well known to require lengthy description. It still holds first place among the dark red Roses, and is one of the most satisfactory to grow. A rich crimson-scarlet, simply a niass of bloom when at its best.

General Washington. Bright red, with crimson sliade; large, full and free bloomer.

Madame Charles Wood. A splendid crimson; large and full; very free bloomer.

Madame Plantier. Pure white and a free bloomer; unrivaled for hedges or ceme. tery use. the very symbol of beauty and elegance. Nearly all the varieties are strong, robust growers, perfectly hardy, and deserve rich culture. There are annual and perpetual bloomers, that are highly cultivated, and will give two or three flowers to the other one's crop; but the prettiest flowers are found among the annual bloomers.

Perpetual White. White; blooms in clusters.

Crimson Moss. Very distinct in color and growth.

\section{CLIMBING ROSES}

Roses of this class are valuable for training on trellises and arbors, covering verandas and buildings. They are rapid growers, and produce great quantities of handsome bloom.

Bartimore Belle. Pale blush, variegated carmine, rose and white; duuble.

Crimson Rambler. The greatest Climbing Rose of its color in existence, small plants making a growth of 10 to 20 feet in a single season, producing in marvelous profusion large trusses of flowers, pyramidal in form. When in full bloom it is a vivid mass of crimson beauty. Perfectly hardy. 


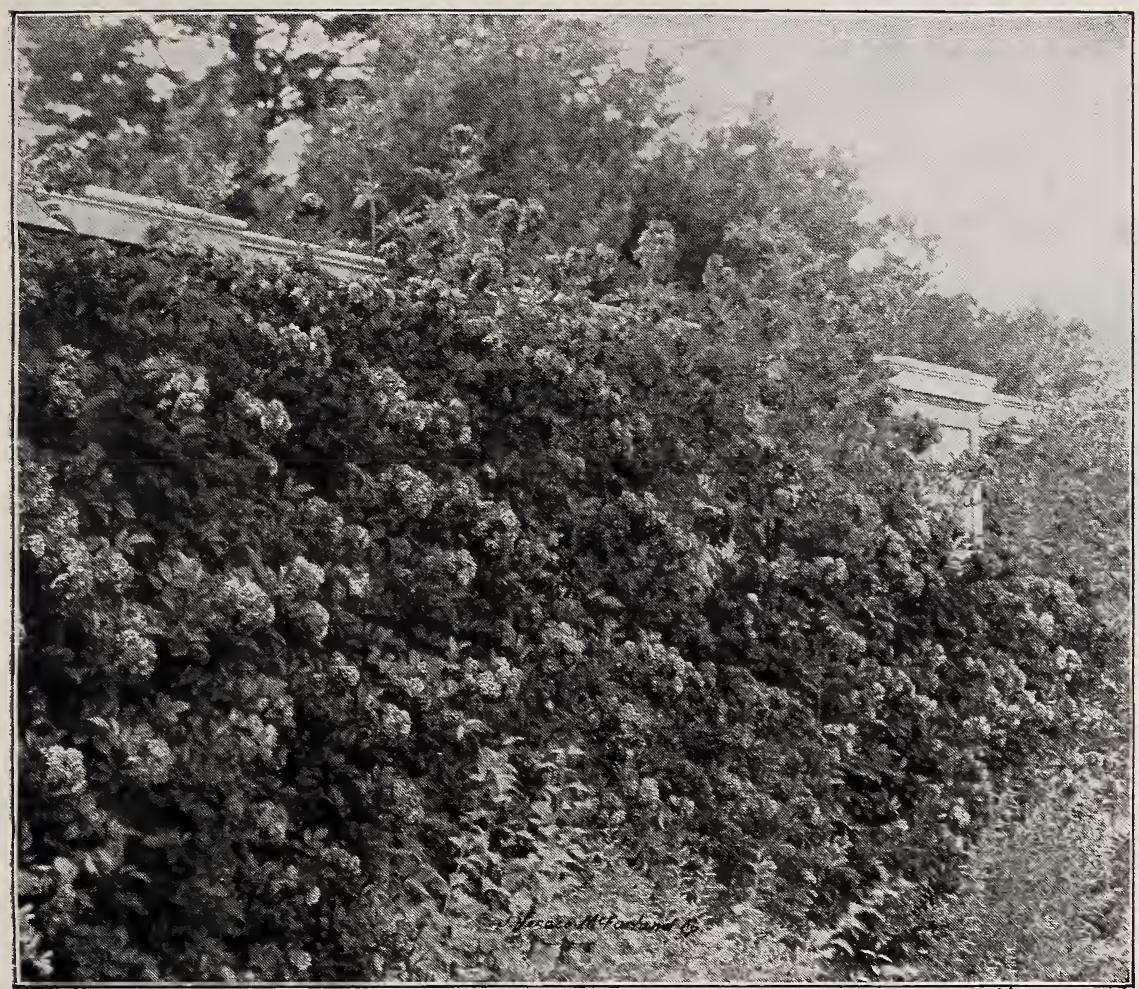

CRIMSON RAMBLER (See preceding page)

\section{CLIMBING ROSES, continued}

Yellow Rambler. The only hardy yellow Climbing Rose in cultivation, and as such is almost indispensable. Identical with Crimson Rambler, except the flowers, which are deep golden yellow and fragrant.

White Rambler. Flowers are of the size of a silver quarter, partly filled, very fragrant, and in color pure white, tinged with blush; borne in clusters.

Pink Rambler. Same as White Rambler, except color of flowers, which are brilliant light carmine.

Empress of China. A remarkably stronggrowing variety, attaining a height of 15 to 25 feet in a single season; produces hundreds of finely formed buds and flowers; color soft dark red, changing to lighter red or pink, like an apple blossom. A great Rose.

Greville, or Seven Sisters. Flowers in large clusters; varies in color from white to crimson.

Marechal Niel. Famous in the South as the acme of perfection; superb; extra large, deep and double flowers of delicious fragrance; color deep golden yellow.

Prairie Queen. Color bright pink, sometimes with a white stripe; very double, full and glotular.
Queen of the Prairie. Extra strong growth and free annual bloomer; bright, rosy red; the strongest climber of all.

Reine Marie Henriette. Rich cherrycrimson; one of the finest hardy Climbing Roses.

Tennessee Belle. Graceful and slender in growth; bright pink flowers in clusters.

\section{ROSA RUGOSA (Japanese Roses)}

Glossy green foliage. Seems to be insect proof. Large single flowers in red and white, which are succeeded by large red fruit, making them particularly attractire in late summer and autumn. Desirable also as a hedge plant.

\section{TREE ROSES}

Tree or standard form. Budded on stems 3 to 4 feet high. We have these in assorted colors and best rarieties.

WICHURAIANA, or MEMORIAL ROSE

Hardy. This is a new race of rapid-creeping habit of growth. Invaluable for covering the ground, stumps of trees, pillars, posts, trellises, rocky slopes and embankments, growing where other Roses could not possibly live. Perfectly hardy and will surrive the severest winters in any climate, soil, expo. sure, remaining green up to Christmas; flowers borne in the utmost profusion; delightfully fragrant. 


\section{The Maryland High Pressure Sprayer}

\section{THE BEST IN THE WORLD}

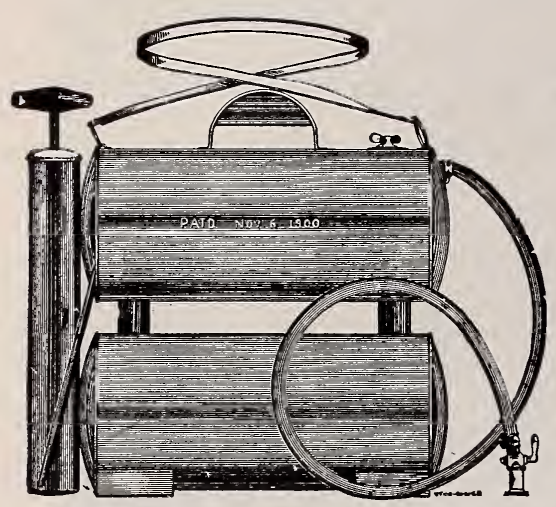

Complete with 30 inches hose, patent hose-band, faucet and nozzle

Patented November 6, 1900

Four gallons solution carried easily with shoulder strap, leaving hands free to direct the spray.

The Maryland High Pressure Sprayer is made with double cylinders of tinned sheet steel (is also made of copper), hence is capable of a very high pressure. It will throw a fine stream over and into the average fruit tree; and once charged it will work continuously. Its shape makes it handy and convenient to carry. It is light, while strong, weighing but seven pounds. By using an extra hose the large body of fine spray can be carried with full force into the top of the highest tree, by the use of a long stick, wired on the end, to raise the nozzle where wanted. Extra hose furnished, also coupling for hose.

It is tested to a very high pressure, and is practically $\mathrm{n}$ on explosive; it is perfect in mechanical appointments, and wondrously perfect in execution.

\section{ADAPTED TO THE FOLLOWING USES:}

1. It is best for rapid work and labor-saving.

2. For killing potato bugs and insects of every nature.

3. For spraying fruit trees.

4. For spraying field crops of all kinds.

5. For keeping flies from live stock during the summer by spraying with Cattle Fly Killer Oil.

6. For white-washing the walls of poultry houses and cow stables.

7. For spraying tobacco and hops in field.

8. For sprinkling floors evenly with oil or water.

9. As a fire extinguisher.

10. For disinfecting purposes.

11. For greenhouse and nursery work.

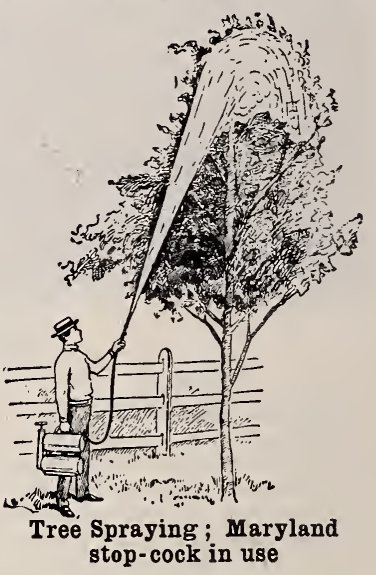

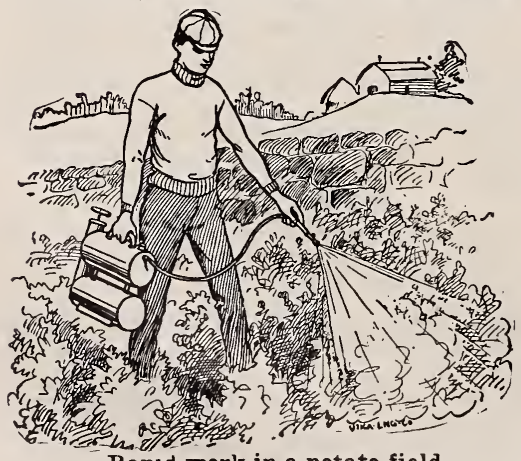

Rapld work in a potato field
Directions:-Put in two or three gallons of what is required. Close faucet and fillerhole tight. Work the pump a quarter to half a minute, then turn the faucet and direct the spray where wanted. This gives you fifteen minutes' continuous work with a very fine or coarse spray, narrow or wide spread, as you wish, all controlled by turning the faucet. Remove both pieces of nozzle for tree spraying with coarse spray.

Rinse out your sprayer after using. Oil leather valve occasionally. Rinse out pump with kerosene to clean it. To drive out all water, take off hose and close front part with your finger; pump in a good pressure, then reinove finger, and all substance will blow out.

Galvanized Iron, No. 40, each complete, $\$ 5.50$; 16-oz. copper, No. 20 , \$8. 


\section{HOW AND WHEN TO SPRAY}

\begin{tabular}{|c|c|c|c|c|c|}
\hline PLANTS & Ist Appication & 2d Application & 3d Application & 4th Appiication & 5th Application \\
\hline $\begin{array}{l}\text { APPLE - Canker } \\
\text { worm, codling- } \\
\text { moth, scab. }\end{array}$ & $\begin{array}{l}\text { Spray before } \\
\text { buds start, us- } \\
\text { ing copper snl- } \\
\text { phate solution. }\end{array}$ & $\begin{array}{l}\text { After the } \\
\text { blossoms have } \\
\text { formed, but be- } \\
\text { fore they open, } \\
\text { Bordeaux and } \\
\text { Paris green. }\end{array}$ & $\begin{array}{l}\text { Within a } \\
\text { we k after } \\
\text { blossoms have } \\
\text { fallen, Bor- } \\
\text { deaux and } \\
\text { Parisgreen. }\end{array}$ & $\begin{array}{l}10 \text { to } 14 \text { days } \\
\text { later, repeat. }\end{array}$ & $\begin{array}{l}10 \text { to } 14 \text { days } \\
\text { later, Bor. } \\
\text { deaux or weak } \\
\text { copper sul- } \\
\text { phate. }\end{array}$ \\
\hline $\begin{array}{l}\text { CHERRY }-\mathrm{R} \text { ot } \\
\text { aphis, curculio } \\
\text { and slug. }\end{array}$ & $\begin{array}{l}\text { Before buds } \\
\text { start, use cop- } \\
\text { per sulphate so- } \\
\text { lution. For } \\
\text { aphis, kerosene } \\
\text { emulsion. }\end{array}$ & $\begin{array}{l}\text { When fruit } \\
\text { has set, Bor- } \\
\text { deaux and Paris } \\
\text { green. }\end{array}$ & $\begin{array}{l}10 \text { to } 12 \text { days } \\
\text { later, it signs } \\
\text { of rot appear, } \\
\text { repeat. }\end{array}$ & $\begin{array}{l}10 \text { to } 12 \text { days } \\
\text { lat er. copper } \\
\text { sulphate solu- } \\
\text { tion weak. }\end{array}$ & $\begin{array}{l}\text { Repeat if nec- } \\
\text { cessary. }\end{array}$ \\
\hline $\begin{array}{l}\text { CURRANT- } \\
\text { Worm s, mil- } \\
\text { dew. }\end{array}$ & $\begin{array}{l}\text { As s o on as } \\
\text { worms are seeu, } \\
\text { Paris gleen. }\end{array}$ & $\begin{array}{l}\text { If they reap- } \\
\text { pear repeat, } \\
\text { adding Bor- } \\
\text { deaux for mil- } \\
\text { dew. }\end{array}$ & $\begin{array}{l}\text { If worms } \\
\text { s till trouble, } \\
\text { pyrethrum or } \\
\text { hellebore. }\end{array}$ & & \\
\hline $\begin{array}{l}\text { GOOSEBERRY - } \\
\text { Mildew, worms. }\end{array}$ & $\begin{array}{l}\text { As leaves } \\
\text { open, Bordeaux } \\
\text { and Paris green. }\end{array}$ & $\begin{array}{l}\text { In } 10 \text { to } 14 \\
\text { days, repeat } \\
\text { with both. }\end{array}$ & $\begin{array}{l}10 \text { to } 14 \text { days } \\
\text { later, sulphide } \\
\text { of potassium } \\
\text { on English va- } \\
\text { rieties. }\end{array}$ & $\begin{array}{l}10 \text { to } 14 \text { days } \\
\text { later, repeat if } \\
\text { necessary. }\end{array}$ & $\begin{array}{l}\text { If mildew } \\
\text { persists after } \\
\text { erop is gatl- } \\
\text { ered,Bordeaux. }\end{array}$ \\
\hline $\begin{array}{l}\text { GRAPE - Flea- } \\
\text { beetle, fungous } \\
\text { diseases. }\end{array}$ & $\begin{array}{l}\text { Before buds } \\
\text { burst, copper } \\
\text { sulphate solu. } \\
\text { tion and Paris } \\
\text { green. }\end{array}$ & $\begin{array}{l}\text { When first } \\
\text { leaves are half } \\
\text { grown, Bor - } \\
\text { deaux and Paris } \\
\text { greeu. }\end{array}$ & $\begin{array}{l}\text { As soon as } \\
\text { fruit lias set, } \\
\text { repeat. }\end{array}$ & $\begin{array}{l}10 \text { to } 14 \text { days } \\
\text { later, Bor- } \\
\text { deaux mixture } \\
\text { if disease is } \\
\text { present. }\end{array}$ & $\begin{array}{l}\text { If necessary, } \\
\text { very weak cop- } \\
\text { pe } r \text { sulphate } \\
\text { solution. }\end{array}$ \\
\hline $\begin{array}{l}\text { NURSERY STOCK- } \\
\text { Fungous dis- } \\
\text { eases. }\end{array}$ & $\begin{array}{l}\text { When buds } \\
\text { burst,Bordeaux. }\end{array}$ & Repeat at in & tervals of 10 to & 14 days. & \\
\hline $\begin{array}{l}\text { PEACH,APRICOT- } \\
\text { Leaf-curl, cur- } \\
\text { culio, mildew } \\
\text { and rot. }\end{array}$ & $\begin{array}{l}\text { Before buds } \\
\text { swell, copper } \\
\text { sulphate solu- } \\
\text { tion. }\end{array}$ & $\begin{array}{l}\text { As soon as } \\
\text { fruit has set, } \\
\text { Bordeaux and } \\
\text { Paris green. }\end{array}$ & $\begin{array}{l}10 \text { to } 12 \text { days } \\
\text { later, repeat. }\end{array}$ & $\begin{array}{l}10 \text { to } 12 \text { days } \\
\text { later, repeat. }\end{array}$ & $\begin{array}{l}\text { If rot persists } \\
\text { use very weak } \\
\text { copper sul- } \\
\text { phate solution } \\
\text { every } 5 \text { to } 7 \\
\text { days. }\end{array}$ \\
\hline $\begin{array}{l}\text { PEAR- } \\
\text { Leaf bligh t, } \\
\text { scab,psylla and } \\
\text { codling-moth. }\end{array}$ & $\begin{array}{l}\text { Before buds } \\
\text { start, copper } \\
\text { sulphate solu- } \\
\text { tion. }\end{array}$ & $\begin{array}{l}\text { Within a week } \\
\text { after blossoms } \\
\text { fall. Bordeaux } \\
\text { and Paris green. }\end{array}$ & $\begin{array}{l}10 \text { to } 12 \text { days } \\
\text { later, repeat. }\end{array}$ & $\begin{array}{l}10 \text { to } 16 \text { days } \\
\text { later, B or - } \\
\text { deaux. }\end{array}$ & $\begin{array}{l}10 \text { to } 16 \text { days } \\
\text { la ter. B o r - } \\
\text { deaux. }\end{array}$ \\
\hline $\begin{array}{l}\text { PLUM - B l a e k } \\
\text { knot, rot and } \\
\text { all fungous dis- } \\
\text { eases, cureulio. }\end{array}$ & $\begin{array}{l}\text { As buds start, } \\
\text { copper sulphate } \\
\text { solution. C nt } \\
\text { out knot and } \\
\text { burn. }\end{array}$ & $\begin{array}{l}\text { When fruit } \\
\text { has set, Bor - } \\
\text { deaux and Paris } \\
\text { green. }\end{array}$ & $\begin{array}{l}10 \text { to } 12 \text { days } \\
\text { later, repeat. }\end{array}$ & $\begin{array}{l}10 \text { to } 20 \text { days } \\
\text { later, B o r } \\
\text { deaux. }\end{array}$ & $\begin{array}{l}\text { Weak copper } \\
\text { sulphate solu- } \\
\text { tion, as is nec- } \\
\text { essary. }\end{array}$ \\
\hline $\begin{array}{l}\text { QUINCE - L e a f } \\
\text { and fruit spot, } \\
\text { rot. }\end{array}$ & $\begin{array}{l}\text { Before buds } \\
\text { start, e op e r } \\
\text { sulphate solu- } \\
\text { tion. }\end{array}$ & $\begin{array}{l}\text { When fruit } \\
\text { has set, Bor- } \\
\text { deaux and Paris } \\
\text { green. }\end{array}$ & $\begin{array}{l}10 \text { to } 12 \text { days } \\
\text { later, repeat. }\end{array}$ & $\begin{array}{l}10 \text { to } 20 \text { days } \\
\text { later, B or- } \\
\text { deaux. }\end{array}$ & $\begin{array}{l}\text { Bordeaux or } \\
\text { copper sulphate } \\
\text { solution, as } \\
\text { necessary. }\end{array}$ \\
\hline $\begin{array}{l}\text { RASPBERRY, } \\
\text { BLACKBERRY- } \\
\text { Anth r acnose, } \\
\text { rust. }\end{array}$ & $\begin{array}{l}\text { Cut out badly } \\
\text { diseased canes. } \\
\text { Spray with cop- } \\
\text { per sulphat } \\
\text { before growth } \\
\text { starts. }\end{array}$ & $\begin{array}{l}\text { When new } \\
\text { canes are one } \\
\text { foot high, spray } \\
\text { with Bordeaux } \\
\text { mixture. }\end{array}$ & $\begin{array}{l}10 \text { to } 12 \text { days } \\
\text { later, weak } \\
\text { copper sul- } \\
\text { phatesolution. }\end{array}$ & $\begin{array}{l}\text { When erop } \\
\text { is gathered re- } \\
\text { move old canes, } \\
\text { thin new ones } \\
\text { and spray with } \\
\text { Bordeaux mix- } \\
\text { ture. }\end{array}$ & \\
\hline $\begin{array}{l}\text { ROSE - M il dew, } \\
\text { black spot, red } \\
\text { spider, aphis. }\end{array}$ & $\begin{array}{l}\text { Mildew. Keep } \\
\text { heating pipes } \\
\text { painted with } \\
\text { equal parts lime } \\
\text { and sulphur, } \\
\text { mixed with } \\
\text { water toa paste. }\end{array}$ & $\begin{array}{l}\text { Black spot. } \\
\text { Spray plants } \\
\text { once a week } \\
\text { with weak cop- } \\
\text { per sulphate. }\end{array}$ & $\begin{array}{l}\text { Red spider. } \\
\text { K e ros e n e } \\
\text { e mulsion to } \\
\text { under side of } \\
\text { foliage. }\end{array}$ & $\begin{array}{l}\text { Aphis. Ker- } \\
\text { osene e } \mathrm{mul} \text { - } \\
\text { sion. }\end{array}$ & \\
\hline $\begin{array}{l}\text { STRAWBERRY- } \\
\text { Rust. }\end{array}$ & $\begin{array}{l}\text { Just before } \\
\text { blossom opens, } \\
\text { Bordeaux and } \\
\text { Paris green. }\end{array}$ & $\begin{array}{l}\text { When fruit } \\
\text { has set, Bor- } \\
\text { deaux or weak } \\
\text { copper sulphate } \\
\text { solution. }\end{array}$ & $\begin{array}{l}\text { As soon as } \\
\text { berries are har- } \\
\text { vested, Bor- } \\
\text { deaux, if to } \\
\text { keep longer. }\end{array}$ & & \\
\hline
\end{tabular}

\section{SPECIAL NOTES}

For BLACK KNOT on cherries and plums, eut out and destroy by burning the diseased parts as soon as discovered. For APHIS on all plants use kerosene emulsion. If RED RUST appears, the entire stools affected should be cut out and burned. YOUNG PLANTS should be sprayed with Bordeaux mixture at the time of the first and third applications to bearing plants. 
Adam's Needle .......... 62 Akebia ................. 64 Almonds.............33, 55 Althæa ................. 55,63 Ampelopsis ...........6 64 Apples ............... 5-13 Apricots ............. 30 Arborvitæ........51, 52, 63 Aristolochia ...........64 Ash ...............46, 51 Asparagus ............. 44 Azaleas ............... 55 Baby Rambler.......... 66 Baccharis .............. 55

Balın of Gilead......... 52 Balsam................. 52 Barberry.............55, 63 Basswood .............4 47 Beech ................ 46 Berberis ........... 55,63 Birch ...............46, 51 Blackberries ........... 40 Bladder Senna ........... 55 Bleeding Heart.......... 55 Box .................. 52 Box Elder.............. 46 Bridal Wreath........... 59 Butternuts .............. 33

Callicarpa ............. 55 Calycanthus............ 56 Catalpa.............. 46 Cedar .................... 52 Cherries.............28-30 Cherry............47, 51 Chestnuts..............32, 33 Clematis ..............6 64 Clethra................. 56 Climbers and Creepers .64, 65 Cornus .........47, 51, 56 Cottonwood............. 50 Crab Apples............. 12 Crab, Flowering .......46, 47 Cranberry Bush .........60 Crape. Myrtle............. 56 Cucumber Tree.......... 4 ๙ Currant, Flowering........ 56 Currants .................38 Cypress .........47, 52, 53 Deciduous Trees .......46-50 Deutzia................ 56 Distances for Planting.... 4 Dogwood .........47, 51, 56 Dutchman's Pipe........6 64 Elæagnus ............. 57 Elder ............... 56 EIm ..............47, 51

Erianthus ............6 62 Eulalia................6 62 Euonymus ..........52, 57 Evergreen Thorn ......57, 63 Evergreens ..........51-53

Exochorda ............. 57 Figs ................. 43 Filberts ............... 33
Fir .............. 52 Flowering and Other

Shrubs.............55-63

Forsythia ............... 57

Fringe Tree.........47, 57

Fruit Department .......5-32

Ginkgo 'I'ree........... 47

Golden Bell ............ 57

Golden Chain ........... 47

Golden Glow ............ 57

Gooseberries ................... 37

Grapes...............35-37

Halesia............... 57

Hawthorn ............. 47

Hazel ................. 57

Hazelnuts ............... 33

Hedge-plants........... 63

Hercules' Club .......... 47

Hibiscus .............. 55

Honeysuckle.........57, 65

Hop Tree ............. 58

Horse-chestnut......... 47

Horse-radish ........... 44

How and When to Spray.. 71

Hydrangea ............ 58

Hypericum ............ 57

Indigo Bush........... 58

Insecticides and Fungicides

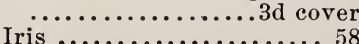

Ivy .............64, 65

Japanese Hardy Orange .. 34

Jessamine.............65 65

Judas Tree............ 47

Juneberry............. 40

Juniper ............... 52

Kentucky Coffee Tree .... 47

Kerria .............. 58

Koelreuteria............ 47

Laburnum.............. 47

Larch ............... 47

Lilacs ................... 58

Linden ............... 47

Locust .................. 47

Lonicera ..............6 65

Maidenhair Tree........ 47

Magnolias ........48, 49, 52

Mahonia.............. 52

Maples................ 48

Maples, Japan.......... 48

Mock Orange...........6 61

Mountain Ash........46, 51

Mulberries ............. 34

Mulberry, Weeping...... 51

Nectarines ............ 31

Number of trees and plants

to an acre ............ 4

Nut-bearing trees ........32-33

Oak .................. 49

Orange, Japanese Hardy . 63

Oriental Plane........... 50

Ornamental Department.45-69

Ornamental Grasses..... 62
Osage Orange $\ldots \ldots \ldots \ldots \ldots 63$

Pampas Grass...........6 62

Paulownia ............ 50

Peach, Flowering......... 50

Peaches .............17-24

Pears ..................14-16

Pecans ................. 33

Peonies ................ 59

Perennial Pea .......... 59

Persimmons............ 34

Pie-plant.............. 44

Pine ................. 53

Plane Tree.............. 50

Plums ..........25-27, 59

Plums, Japanese......26, 27

Poplar ............... 50

Privet ..............59, 63

Quince, Japan ...........58, 63

Quinces................ 31

Raspberries...............38, 39

Red Bud ..............4 47

Retinospora............... 53

Rhododendron ............. 54

Rhubarb............. 44

Rocky Mountain Cherry .. 34

Rose Acacia ........... 47

Rose of Sharon............ 55

Roses ..............66-69

Rudbeckia............ 57

Siberian Pea ............ 59

Silver Bell ............ 57

Snowball................... 60

Snowberry ...........60, 61

Snowdrop ............... 57

Smoke Tree .............. 57

Sophora.............. 50

Spindle Tree ........... 57

Spireas .............59, 60

Sprayer .................. 70

Spruce.............53, 63

St. John's Wort ......... 57

Strawberry Tree.......... 57

Strawberries .........41-43

Sumach ................ 61

Sweet Gum............ 50

Syringa ................ 61

Tamarix................ 61

Texas Umbrella Tree.... 50

Trumpet Flower......... 65

Tulip Tree ............ 5n

Venetian Sumac........... 57

Virginia Creeper ......... 64

Virgin's Bower.......... 64

Walnuts ................. 33

Wayfaring Tree ........ 62

Weeping Trees........... 51

Weigela............61, 62

Willow .............50, 51

Wineberry ............. 39

Wistaria .............6 65

Yellow-wood ............... 50

Yew ................. 53

Yucca................6. 62

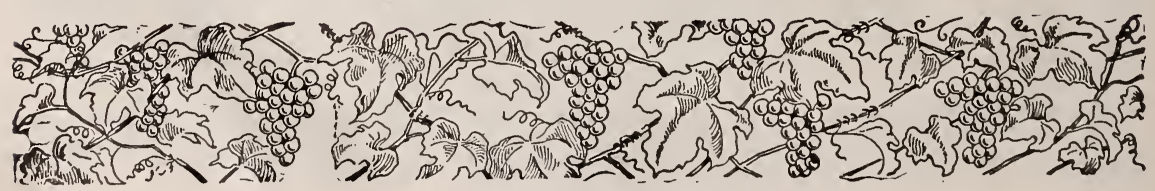




\section{ENEMIES OF FRUIT TREES AND PLANTS}

The insect and fingous enemies of the orchard and fruit-garden have increased rapidiy of late years, on account of which we are often called on for information as to combating with them succossfully. We have given below a few simple formulas that any one can make. In order to have perfect fruit and much of it, it is very negessary. to spray orchards and gar. dens. Wo can furnish an up-to-date spiray pump for applying these solutions:

For further information about insects, insecticides and fungicides, we stuggest your sending to your State Entomologist, or United States Entomologist, Washington, D. C.

\section{INSECTICIDES AND FUNGICIDES}

Fermula 1.-Paris Green (Poisonous). One fourth of a pound of Paxis green dissolved in 50 to 100 gallons of water. Stir well. For folisge-eating insects.

Formula 2. - Iondon Purple. One-fourth pound of London purple to 75 gallons of water. Stir well.

Formula 8. - Kerosene Emulsion. Dissolve $3 / 8$ lb. whale-oil soap in one gallon of water, and while boiling hot remove from fire and add two gallons of kerosene and stir vigorously with paddle, force pump or spoon until it is the consistency of cream. Set aside to cool; then dilute with ten to twenty parts cold water. For sucking insects.

"WEED'S SPRAYINa CROPS." - Why, When and How, is a valuable work on the subject. It can be had of the Deming Company, Salem, Ohio.

\section{Inspection and Fumigation}

$\mathrm{O}$ UR stock is inspected every twolve months by the State Entomologist (a faesimaile of the Certificate of Inspection is given below), and in addition to this we thoroughly fumigate all stock before shipment from Nurseries. Our fumigating plant is one of the best equipped in the country.

\section{Certificate of Inspection}

This is to Certify. That we examined the Nursery Stock of Franklin Davis Nursery Co, growing in their Nurseries at Mitchellville, State of Maryland, in accordance with the Laws of Marytand, 1898, Chapter 289, Section 58, and that said marseries and premises are apparently free, so far as can be determined by inspection, from the san José Scale, Peach Yellows, Pear Blight and other dangerously injurious insect pests, and plant diseases.

THOMAS B. STMONS, Stale Entomologist

COLLEGE PARK, MD.

J. B. S, NORTON, State Pathologist

Every customer recelves a copy of Certificate of Inspection vith bis shipment 
THE FRANKLIN DAVIS NURSERY COMPANY

Baltimore Maryland 